DOE/SNF/REP-051

Revision 0

RECEVER:

DEC 202000

OSTI

\title{
Shippingport LWBR (Th/U Oxide) Fuel Characteristics for Disposal Criticality Analysis
}

\section{Idaho National Engineering and Environmental Laboratory \\ Lockheed Martin Idaho Technologies Company Idaho Falls, Idaho 83415}

\section{September 1999}

\author{
This report was produced under a quality assurance \\ program that satisfies the requirements of the \\ National Spent Nuclear Fuel Program and DOE/RW-0333P, \\ Office of Civilian Radioactive Waste Management Quality \\ Assurance Requirements Description. However, the historical data \\ presented in this report are unqualified.
}

\author{
Prepared for the \\ U.S. Department of Energy \\ Assistant Secretary for Environmental Management \\ Under DOE Idaho Operations Office \\ Contract No. DE-AC07-94ID13223
}




\section{DISCLAIMER}

This report was prepared as an account of work sponsored by an agency of the United States Government. Neither the United States Government nor any agency thereof, nor any of their employees, make any warranty, express or implied, or assumes any legal liability or responsibility for the accuracy, completeness, or usefulness of any information, apparatus, product, or process disclosed, or represents that its use would not infringe privately owned rights. Reference herein to any specific commercial product, process, or service by trade name, trademark, manufacturer, or otherwise does not necessarily constitute or imply its endorsement, recommendation, or favoring by the United States Government or any agency thereof. The views and opinions of authors expressed herein do not necessarily state or reflect those of the United States Government or any agency thereof. 


\section{DISCLAIMER}

Portions of this document may be illegible in electronic image products. Images are produced from the best available original document. 


\title{
SHIPPINGPORT LWBR (Th/U Oxide) FUEL CHARACTERISTICS FOR DISPOSAL CRITICALITY ANALYSIS
}

\author{
Idaho National Engineering and Environmental Laboratory \\ Lockheed Martin Idaho Technologies Company \\ Idaho Falls, Idaho 83415
}

Revision 0

September 1999

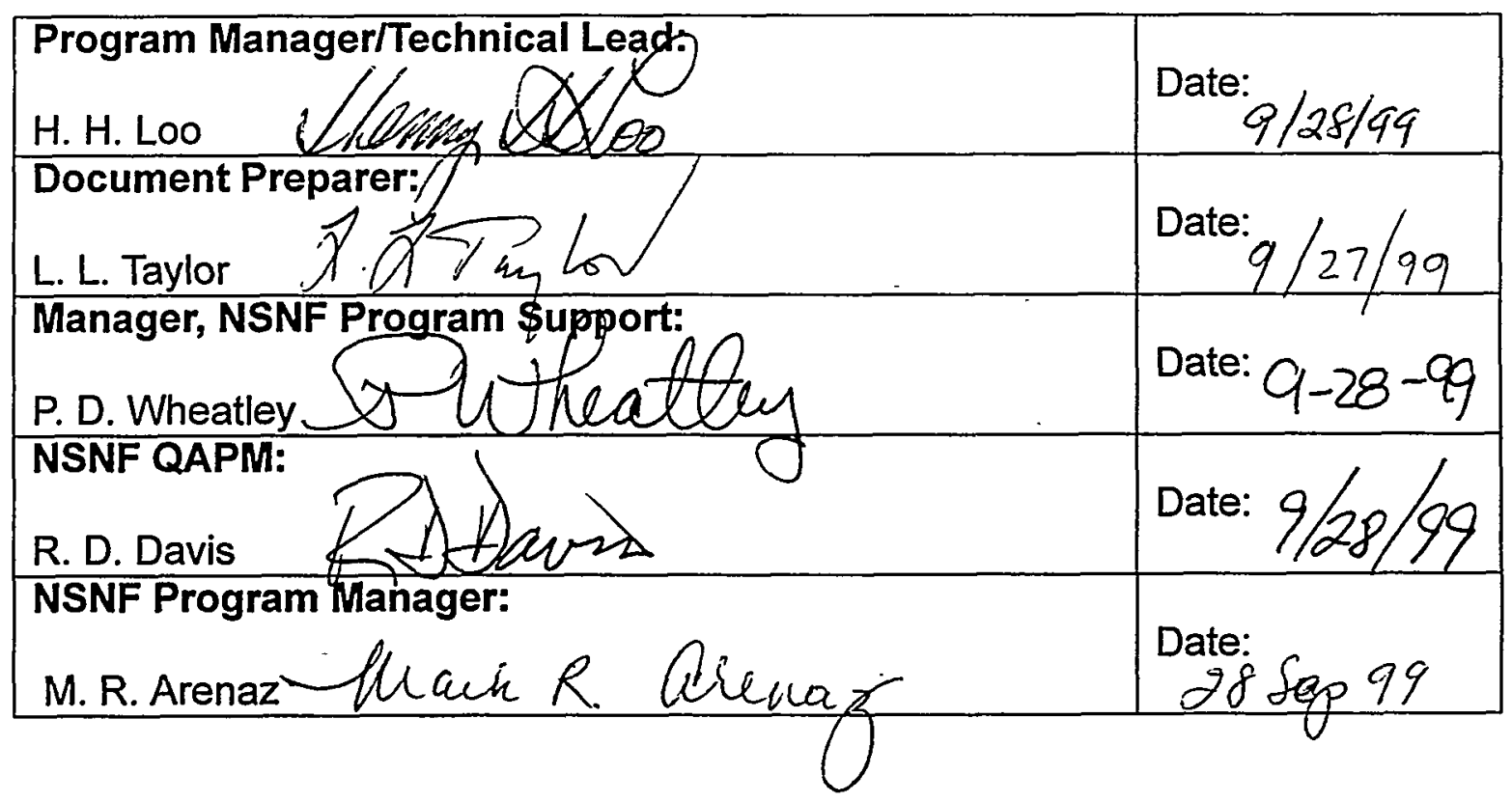

Prepared for the

U. S. Department of Energy

Assistant Secretary for Environmental Management

Under DOE Idaho Operations Office

Contract No. DE-AC07-94ID13223 


\begin{abstract}
DOE-owned spent nuclear fuels encompass many fuel types. In an effort to facilitate criticality analysis for these various fuel types, they were categorized into eight characteristic fuel groups with emphasis on fuel matrix composition. Out of each fuel group, a representative fuel type was chosen for analysis as a bounding case within that fuel group. Generally, burnup data, fissile enrichments, and total fuel and fissile mass govern the selection of the representative or candidate fuel within that group.

The Shippingport LWBR' fuels incorporate more of the conventional materials (zirconium cladding/heavy metal oxides) and fabrication details (rods and spacers) that make them comparable to a typical commercial fuel assembly. The LWBR seed/blanket configuration tested a light-water breeder concept with Th-232/U-233 binary fuel matrix. Reactor design used several assembly configurations at different locations within the same core. The seed assemblies contain the greatest fissile mass per (displaced) unit volume, but the blanket assemblies actually contain more fissile mass in a larger volume; the atom-densities are comparable.
\end{abstract}




\title{
TABLE OF CONTENTS
}

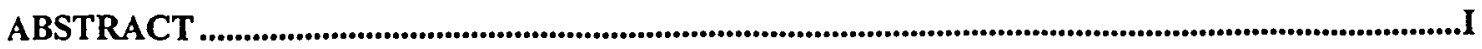

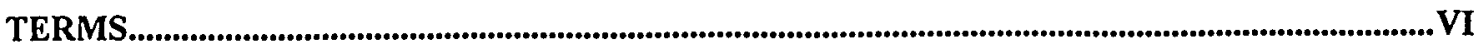

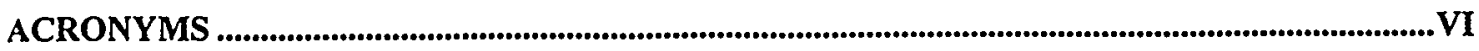

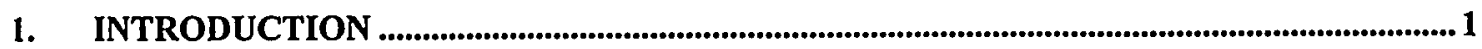

1.1 SHIPPINGPORT LIGHT WATER BREEDER REACTOR, SP LWBR .............................................. 1

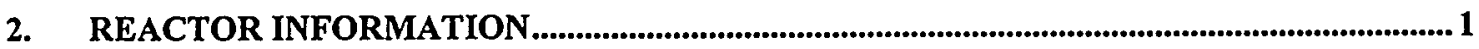

3. DOE SHIPPINGPORT FUEL INFORMATION .......................................................................2

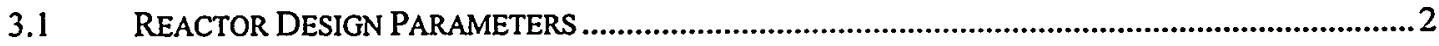

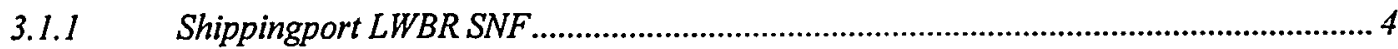

3.1.1.1 Description of SNF from the Seed Region ........................................................................16

3.1.1.1.1 Fuel Pellets from the Seed Region ...................................................................................16

3.1.1.1.2 Fuel Rods from the Seed Region..................................................................................17

3.1.1.1.3 Seed Modules...........................................................................................................19

3.1.1.2 Description of SNF from the Blanket Regions .....................................................................23

3.1.1.2.1 Fuel Pellets from the Blanket Regions .............................................................................24

3.1.1.2.2 Fuel Rods from the Blanket Regions ............................................................................25

3.1.1.2.3 Fuel Assemblies from the Blanket Regions ....................................................................26

3.1.1.3 Description of SNF from the Reflector Region ...................................................................30

3.1.1.3.1 Fuel Pellets from the Reflector Region ...........................................................................30

3.1.1.3.2 Fuel Rods from the Reflector Region.............................................................................30

3.1.1.3.3 Fuel Assemblies from the Reflector Region.....................................................................31

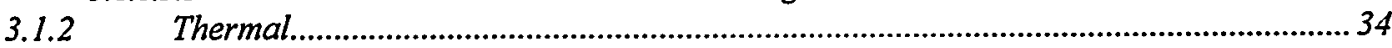

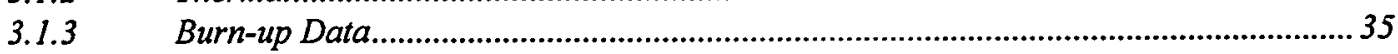

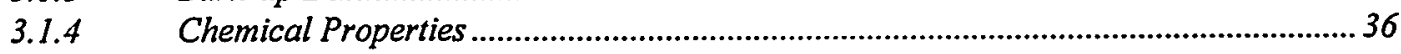

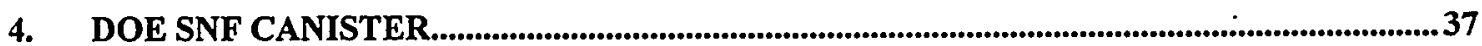

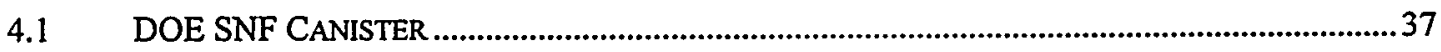

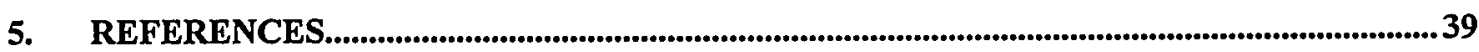

APPENDIX A: SHIPPINGPORT FUEL INVENTORIES..............................................................

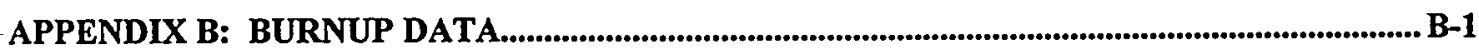




\section{Tables}

TABLE 3-1. ISOTOPIC COMPOSITION OF THE URANIUM USED IN FABRICATING THE FUEL .......................... 4

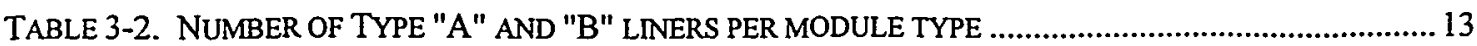

TABLE 3-3. NUMBERS OF FUEL RODS AND ASSEMBLIES IN STORAGE .................................................. 14

TABLE 3-4. SUMMARY OF MASSES FOR INTACT AND PARTIALLY DERODDED ASSEMBLIES FROM ALL CORE

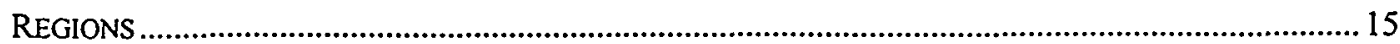

TABLE 3-5. CHARACTERISTICS OF PELLETS IN THE SEED REGION...................................................... 17

TABLE 3-6. AS-BUILT CHARACTERISTICS OF SEED FUEL RODS.............................................................. 18

TABLE 3-7. FURTHER AS-BUILT CHARACTERISTICS OF FUEL RODS IN THE SEED REGION......................... 18

TABLE 3-8. AVERAGE AS-BUILT CLADDING DIMENSIONS FOR ALL CORE REGIONS ................................. 18

TABLE 3-9. PLENUM SPRING DIMENSIONS FOR ALL CORE REGIONS ........................................................ 18

TABLE 3-10. ESTIMATED MASSES OF UNIRRADIATED FUEL ROD COMPONENTS FOR ALL CORE REGIONS 19

TABLE 3-1 1 . A VERAGE AS-BUILT FISSILE LOADING OF ASSEMBLIES FROM ALL CORE REGIONS ............ 19

TABLE 3-12. COMPOSITION OF THE SEED ASSEMBLY WITH MAXIMUM FISSILE LOADING ........................20

TABLE 3-13. CHARACTERISTICS OF PELLETS IN THE STANDARD BLANKET ……....................................24

TABLE 3-14. CHARACTERISTICS OF PELLETS IN THE POWER FLATTENING BLANKET.................................25

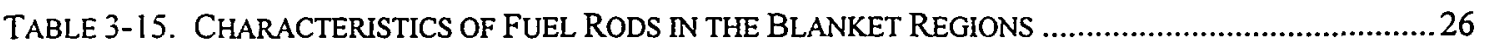

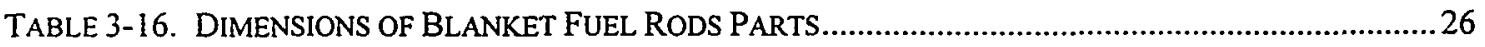

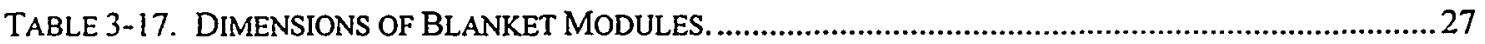

TABLE 3-18. AVERAGE MASSES OF GRID STRUCTURES IN THE BLANKET REGIONS ................................2 27

TABLE 3-19. MAXIMUM NUMBERS OF RODS OF EACH TYPE IN BLANKET AND REFLECTOR MODULES. ... 28

TABLE 3-20. DIMENSIONS OF REFLECTOR FUEL RODS .............................................................................. 30

TABLE 3-21. DIMENSIONS OF REFLECTOR ASSEMBLIES.............................................................................. 31

TABLE 3-22. AXIAL PEAKING FACTORS ESTIMATED FROM PEAK AND AVERAGE BURNUPS .......................35

TABLE 3-23. THERMAL CONDUCTIVITY OF UO $\mathrm{O}_{2}$ AND THORIA FUEL ……...............................................

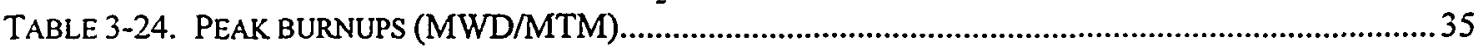

TABLE 3-25. FUEL QUANTITIES ASSUMED FOR THE ORIGEN2 CALCULATIONS …...................................36

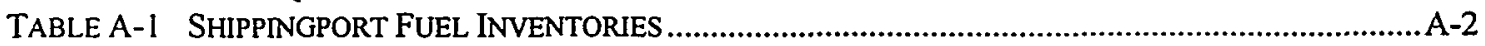

TABLE B-1 PHOTON SPECTRA FOR ACTIVATION PRODUCTS ........................................................... B-2

TABLE B-2 CALCULATED PHOTON SPECTRA FROM ACTINIDES AND THEIR DAUGHTERS IN SEED FUEL B-3

TABLE B-3 CALCULATED PHOTON SPECTRA FROM FISSION PRODUCTS IN SEED FUEL ........................... B-3

TABLE B-4 $\quad \alpha, N$ NEUTRON SOURCES FOR A SHIPPINGPORT LWBR SEED ASSEMBLY * ........................ B-4

TABLE B-5 CALCULATEd SPONTANEOUS FISSION NEUTRON SOURCE FOR SEED FUEL .......................... B-4

TABLE B-6 CALCULATED ISOTOPIC ACTIVITY OF THE SEED FUEL BY YEAR ......................................... B-5

TABLE B-7 THERMAL OUTPUT FOR A SINGLE LWBR SEED ASSEMBLY …........................................ B-9

TABLE B-8 ISOTOPIC ACTIVITY CONCENTRATIONS IN CURIES FOR A SINGLE SEED LWBR ................ B-12

TABLE B-9 ISOTOPIC ACTIVITY CONCENTRATIONS IN CURIES FOR A SINGLE LWBR .......................... B-13

TABLE B-10 - ISOTOPIC ACTIVITY CONCENTRATIONS IN CURIES FOR A SINGLE LWBR ....................... B-14 


\section{FIGURES}

FIGURE 3-1. LWBR CORE IN SHIPPINGPORT REACTOR VESSEL .............................................................

FIGURE 3-2. REACTOR CROSS SECTION FOR ASSEMBLY IDENTIFICATION …..............................................5

FIGURE 3-3. LAYOUT OF FUEL RODS IN A SEED ASSEMBLY ......................................................................

FIGURE 3-4. LAYOUT OF FUEL RODS IN A TYPE I BLANKET ASSEMBLY ...........................................

FIGURE 3-5. LAYOUT OF RODS IN A TYPE II BLANKET ASSEMBLY ..................................................... 8

FIGURE 3-6. LAYOUT OF RODS IN A TYPE III BLANKET ASSEMBLY ............................................................9

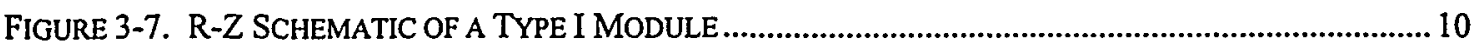

FIGURE 3-8. R-Z SCHEMATIC OF POWER FLATTENING SIDES OF TYPE II AND TYPE III BLANKET MODULES

.

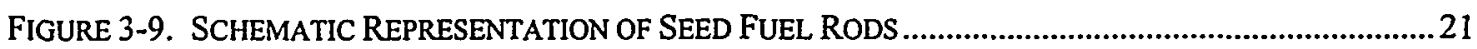

FIGURE 3-10. CROSS SECTIONAL DIMENSIONS IN INCHES OF THE FUEL ASSEMBLIES ................................22

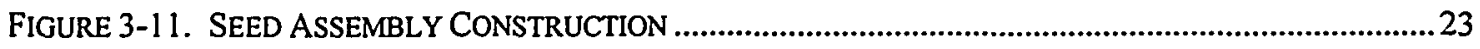

FIGURE 3-12. SCHEMATIC REPRESENTATION OF FUEL RODS FROM THE BLANKET REGIONS ....................29

FIGURE 3-13. SCHEMATIC REPRESENTATION OF REFLECTOR FUEL RODS................................................... 32

FIGURE 3-14. LAYOUT OF RODS IN A TYPE IV REFLECTOR ASSEMBLY ....................................................

FIGURE 3-15. LAYOUT OF RODS IN A TYPE V REFLECTOR ASSEMBLY .....................................................34

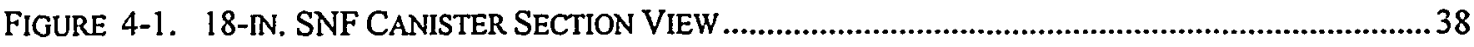

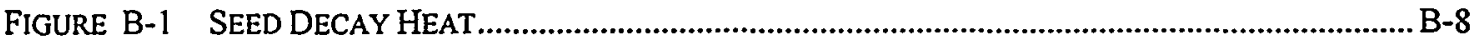


ASSIGNMENT PAGE

\section{SHIPPINGPORT LWBR (Th/U Oxide) FUEL CHARACTERISTICS FOR DISPOSAL CRITICALITY ANALYSIS}

DOCUMENT IDENTIFICATION NUMBER:

DOCUMENT COPY NUMBER:

DOCUMENT HOLDER:

NAME OR POSITION

\section{DOCUMENT CONDITION STATEMENT}

This document is subject to formal change control, audit, and recall; therefore, it should be carefully maintained and kept readily available. The holder identified above is responsible for maintaining this document in an up-to-date conditioning by incorporating subsequent revisions as they become available. This document is property of DOE-EM. On request, reassignment that ends the need for the document, or termination of employment with the DOE-EM, this document must be returned to the NSNF Document Control Coordinator at the following address:

NSNF Document Control Coordinator Lockheed Martin Idaho Technologies Company

P. O. Box 1625

Idaho Falls, ID 83415-3140

Phone: (208) 526-6837

Fax: (208)-526-3730 


\section{Terms}

blanket - core assemblies that contain fertile material to capture excess or escaping neutrons and converting to fissile material

burnup - is a measure of the amount of fissile material consumed before the fuel element is removed from the reactor

fertile - material, that after neutron capture(s) and decay, becomes fissile

fissile $\quad-$ materials which will undergo fission with neutrons of any energy

fissile loading - the amount of fissionable material per unit volume within a fuel pin, assembly, or reactor core

liner - a stainless steel canister used for interim storage of LWBR assemblies; not expected to be a part of the disposal package

seed fuel - the active portion of the nuclear reactor core associated with the bulk of neutrons being generated to sustain criticality

Zircaloy-4 - an improved zirconium alloy (ASTM grade R60805) with a low nickel composition which avoids hydriding and loss of ductility [Ref. 1, p. 324]

\section{Acronyms}

BOL beginning-of-life

ECF_ Expended Core Facility (@ INEEL)

EOL end-of-life

DOE Department of Energy

ICPP Idaho Chemical Processing Plant .

INEEL Idaho National Engineering and Environmental Laboratory

INTEC Idaho Nuclear Technology and Engineering Center (formerly ICPP)

LWBR light water breeder reactor 


\section{Acronyms (cont'd)}

MTHM metric ton heavy metal

MWd/MTHM megawatt-days/metric ton heavy metal

PIE post-irradiation examination

PWR pressurized water reactor

SNF spent nuclear fuel

TBV to be verified

WP waste package 


\section{INTRODUCTION}

\subsection{Shippingport Light Water Breeder Reactor, SP LWBR}

The Shippingport Light Water Breeder Reactor (LWBR) was a small water cooled, U-233/Th-232 cycle breeder reactor developed by the Pittsburgh Naval Reactors to improve utilization of the nation's nuclear fuel resources in light water reactors. The LWBR was operated at Shippingport Atomic Power Station (APS), which was a Department of Energy (DOE) (formerly Atomic Energy Commission)-owned reactor plant.

After final shutdown, the 39 core assemblies of the LWBR were shipped to the Expended Core Facility (ECF) at Naval Reactors Facility at the Idaho National Engineering and Environmental Laboratory (INEEL). At ECF, 12 of the 39 assemblies were dismantled and about 1000 of more than 17,000 rods were removed from the modules for proof-of-breeding and fuel performance testing. Some of the removed rods were kept at ECE, some were sent to Argonne National Laboratory-West (ANL-W) in Idaho and some to ANL-East in Chicago for a variety of physical, chemical and radiological examinations. All rods and rod sections remaining after the examinations were shipped back to ECF, where modules and loose rods were repackaged in liners for dry storage. In a series of shipments, the liners were transported from ECF to Idaho Nuclear Technology Engineering Center (INTEC), formerly the Idaho Chemical Processing Plant (ICPP). The 47 liners containing the fully-rodded and partiallyderodded core modules, the loose rods, and the rod scraps, are now stored in underground dry wells at INTEC.

\section{REACTOR INFORMATION}

The Shippingport LWBR core was operated successfully from September 1977 to October 1, 1982 at the Shippingport APS. At full power, the thermal power output of the reactor was $236.6 \mathrm{MW}$ [Ref. 2, p. 5]. The core operated for 29,047 Effective Full Power Hours (EFPH) over the five-year period of operation [Ref. 2, p. 27].

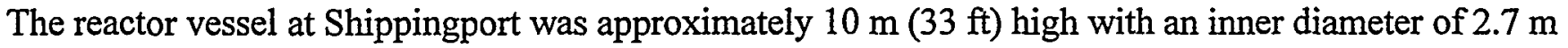
$(9 \mathrm{ft}$ ) and a nominal wall thickness of $22.5 \mathrm{~cm}(8-7 / 8 \mathrm{in})$ [Ref. 3, p. 2]. Within the vessel was a core barrel, a long cylinder that locates fuel assemblies within the vessel. The core barrel was supported in the vessel by a large doughnut-shaped weldment, called the support flange, that rests on top of the vessel. The support flange also served as the entrance point of various types of core instrumentation and safety injection piping. The support flange was clamped in position by a $127 \mathrm{~cm}(50$-inch) thick steel closure head using $15 \mathrm{~cm}$ (6-inch) diameter studs, which were installed in mating bolting flanges of the closure head and reactor vessel [Ref. 3, p. 2]. 


\section{DOE SHIPPINGPORT FUEL INFORMATION}

\subsection{Reactor Design Parameters}

The LWBR was designed as a pressurized, light-water moderated and cooled thermal reactor that utilized the thorium/uranium-233 fuel cycle.

The LWBR core design provided a good simulation of a large LWBR core environment in the interior of the core, and permitted net breeding in the entire core [Ref. 4, p. 15]. Nuclear design of the LWBR core utilized a seed-blanket concept similar to that successfully applied to the first two pressurized water reactor (PWR) cores operated at Shippingport, but with reactivity control provided by core geometry changes (movable fuel) instead of poison rods [Ref. 5, p. 4]. Figure 3-1 shows a plan cross section of the LWBR core installed in the Shippingport pressurized water reactor vessel.

The LWBR core was designed to minimize parasitic neutron absorption in core and structural materials. Among the core design features, which contributed to improved neutron economy in the LWBR, were:

1. Use of movable fuel assemblies to control core reactivity, rather than conventional poison control rods, soluble poison, or burnable poison.

2. Use of peripheral radial and axial thoria reflector blanket regions to reduce neutron leakage from the core.

3. Use of Zircaloy with a low hafnium content for fuel rod cladding and for all structures in the active fuel region except the fuel rod support grids

4. Use of stainless steel (AM-350) rather than Inconel for fuel rod support grids [Ref. 6, p. 3].

The central portion of the core consisted of 12 movable-fuel seed assemblies each surrounded by a stationary blanket assembly [Figure 3-2, from Ref. 7, Figure II-1]. Reactivity in this seed-blanket reactor was controlled by raising and lowering the central movable seeds, a concept that eliminated the need for control poisons [Ref. 8, p. 3]. The $\mathrm{UO}_{2}$-rich seed assemblies generated neutrons, and the fertile fuel in the blanket/reflector assemblies absorbed excess neutrons while producing some fissile material and additional fissions. The fuel and blanket assembly design was optimized to maximize neutron production and minimize neutron loss [Ref. 8, p.8]. The power-flattening regions (see Figure 3-2) actually contained more U-233 mass than the standard blanket regions. Use of this highly loaded power-flattening blanket region produced a relatively uniform power distribution within the interior of the core. Radial and axial zoning of fuel loadings are shown in Figures 3-3 through 3-8. 


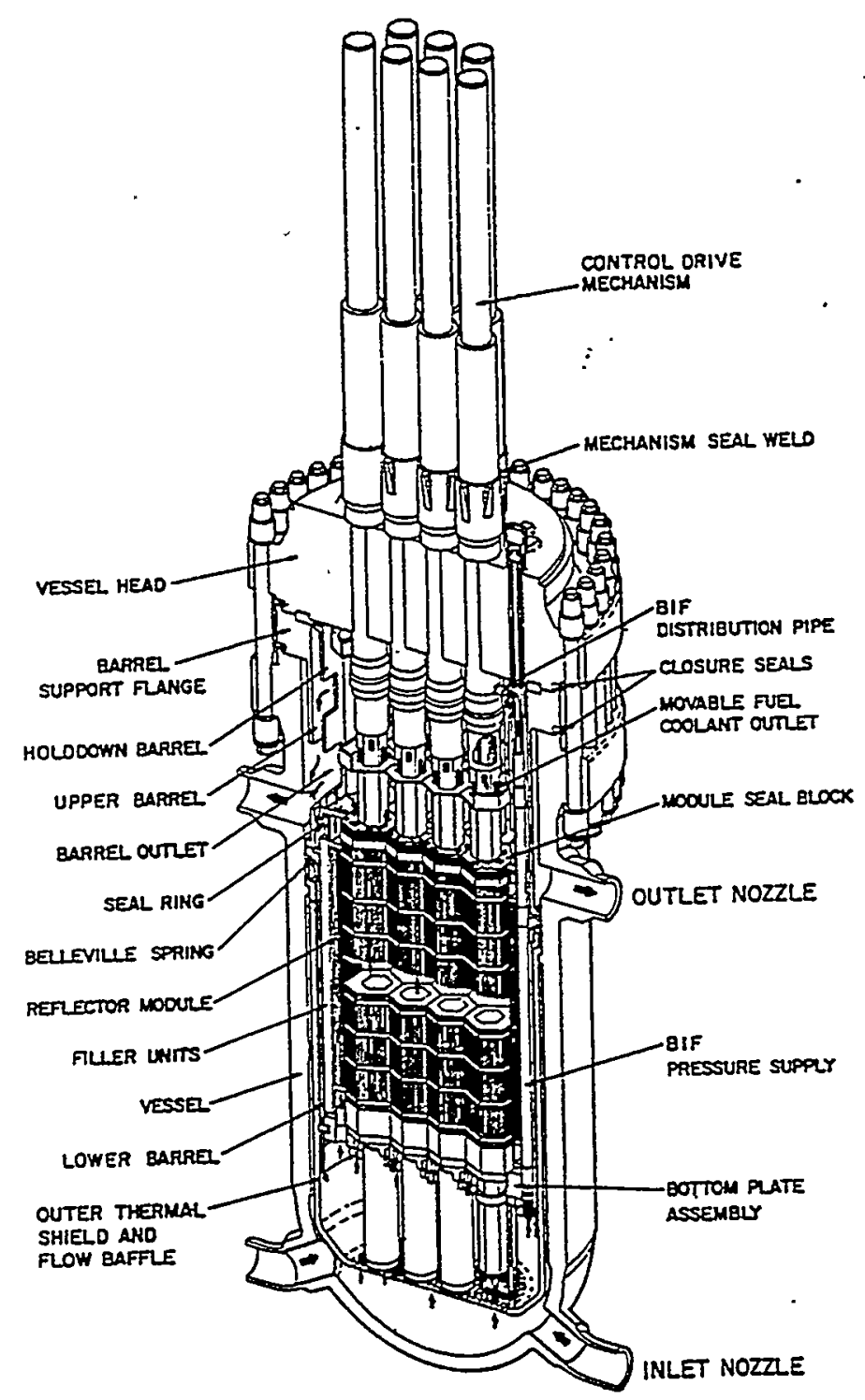

FIGURE 3.1. LWBR CORE IN SHIPPINGPORT REACTOR VESSEL

(WAPD-TM-1208) 


\subsubsection{Shippingport LWBR SNF}

The LWBR core was fueled with fertile Th-232 and fissile U-233, the relative concentrations of which varied axially and radially across the core to improve neutron economy. The uranium that was used in fabricating the fuel was very highly enriched in U-233, but some isotopic impurities were present (Table 3-1). These isotopics represent 'nominal design' values, and other reported/calculated $U$ isotopic values may vary slightly due to blending differences in various batches of fissile material. The design included vertical fuel rods on a triangular pitch with the space between taken up by circulating cooling water. The fuel rods featured cladding tubes loaded with cylindrical ceramic fuel pellets of thoria $\left(\mathrm{ThO}_{2}\right)$ or a mixture of thoria and $\mathrm{UO}_{2}$. Rods were sealed and backfilled with helium at one atmosphere during welding [Ref. 5, p. 70].

The LWBR core contained about 17,290 rods in 39 core assemblies [Ref. 9, p. I-1]. There were 15 types of rods used in the LWBR core to achieve the designed axial and radial zoning. The different rod types required different pellet geometries, so several types of fuel pellets were manufactured. Pellets varied in size, shape, and enrichment. Zircaloy-4 with a low hafnium content was used for the cladding tubes and all other structures (ducting, blanket support posts) in the fuel region, except the grids, which were made of AM-350 stainless steel [Ref. 10, p. 8]. The fuel and fuel components suffered minimal damage during operation. Extensive destructive and non-destructive examinations after shutdown confirmed that the fuel was in good condition with minimal deformation of the cladding and minimal cracking of fuel pellets. Fuel assembly packaging in existing liners, shipping controls, and existing dry-storage have all contributed to fuel 'stability' and virtual elimination of any further interim damage or degradation.

Table 3-1. Isotopic Composition of the Uranium Used in Fabricating the Fuel [from Ref. 6, Table II-2, p. 11]

\begin{tabular}{|c|r|}
\hline Isotope & \multicolumn{1}{|c|}{$\begin{array}{c}\text { Weight } \\
\text { Percent }\end{array}$} \\
\hline U-232 & $<0.001$ \\
\hline U-233 & 98.23 \\
\hline U-234 & 1.29 \\
\hline U-235 & 0.09 \\
\hline U-236 & 0.02 \\
\hline U-238 & 0.37 \\
\hline
\end{tabular}

Core reactivity control was achieved by moving the 12 seed assemblies up and down within the stationary blanket assemblies using individual control drive mechanisms. To shut the reactor down, the bottoms of the seed assemblies were lowered $152-\mathrm{cm}(60$-in) below the bottoms of the blanket assemblies. To start up the reactor, the seed assemblies were raised, thus bringing the fissile uraniumbearing parts of the fuel closer together (Figure 3-9), [Ref. 7, Figure II-3]. 


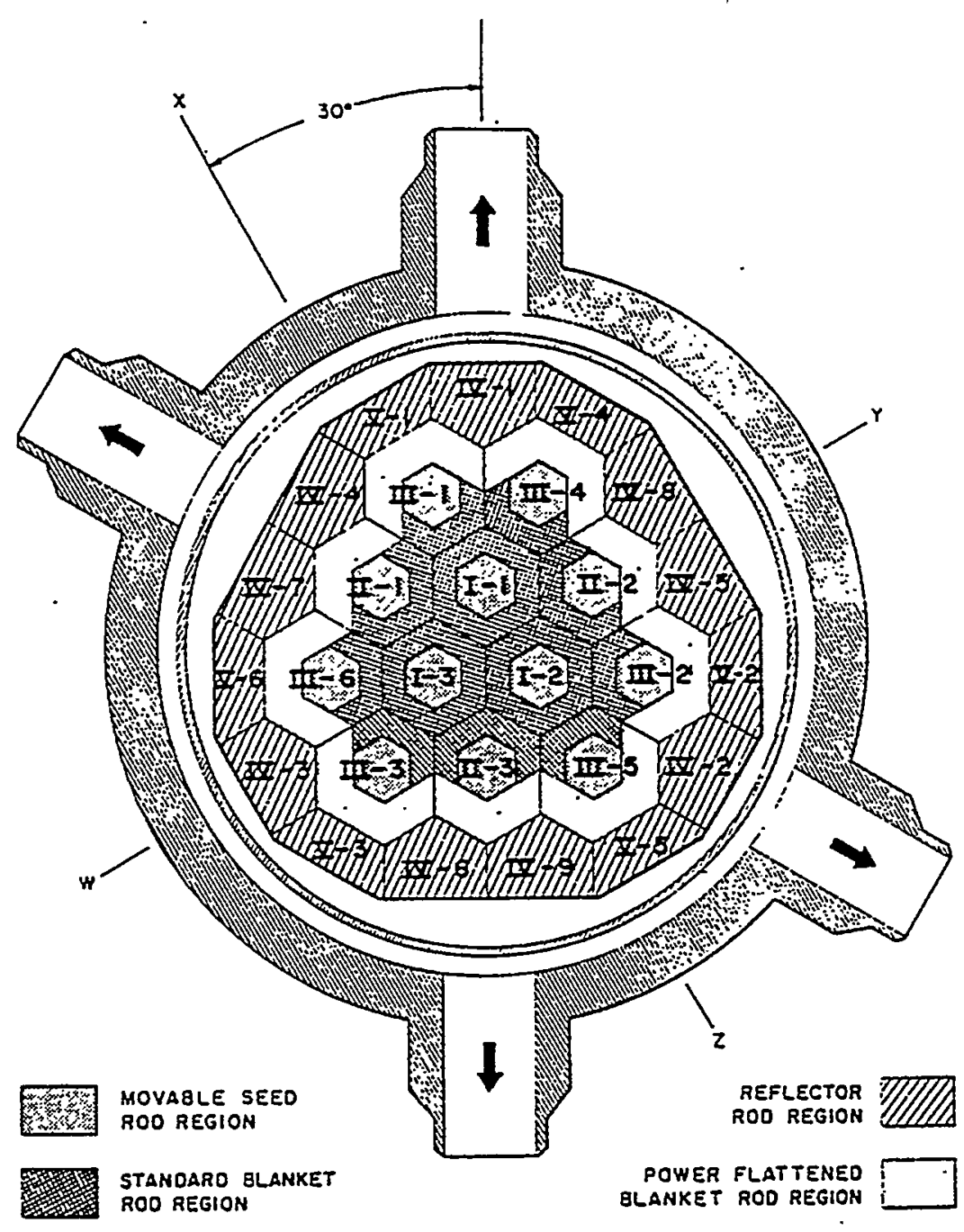

FIGURE 3-2. REACTOR CROSS SECTION FOR ASSEMBLY IDENTIFICATION [Ref. 7, p. 8] 


\begin{tabular}{|c|c|c|c|c|c|c|c|}
\hline & Rod Type' & $\begin{array}{l}\text { Sinary Stack } \\
\text { Length }\end{array}$ & $\begin{array}{l}\text { Enrichment } \\
\text { (U-fissile wt as) }\end{array}$ & $\begin{array}{l}\text { Theoretical } \\
\text { Density }\left(g^{\prime} \mathrm{cm}^{3}\right)^{2}\end{array}$ & $\begin{array}{c}\text { Mass Initial } \\
\text { Fissile (g)/Root }\end{array}$ & $\begin{array}{l}\text { Number of } \\
\text { Rodsfcore }\end{array}$ & $\begin{array}{l}\text { Hlass Initial } \\
\text { Fissile (g)Core }\end{array}$ \\
\hline & 05,06 & $84^{*}$ & 5.995 & 10042 & 34.57 & 3,972 & 137.312 \\
\hline$\sqrt{x^{2}+y^{2}+x^{2}}$ & of & $\pi$ & 4.327 & 10.035 & 2352 & 792 & 18.945 \\
\hline & 03 & $5 \tilde{0}$ & 4.327 & 10.035 & 19.14 & 864 & 16,537 \\
\hline \multirow[t]{2}{*}{$n=n+1+x$} & $01,02,07,08$ & $42^{\circ}$ & 4.327 & 10.035 & 14.33 & 1,800 & 25,794 \\
\hline & & & & & & 7,4 & 198,586 \\
\hline
\end{tabular}

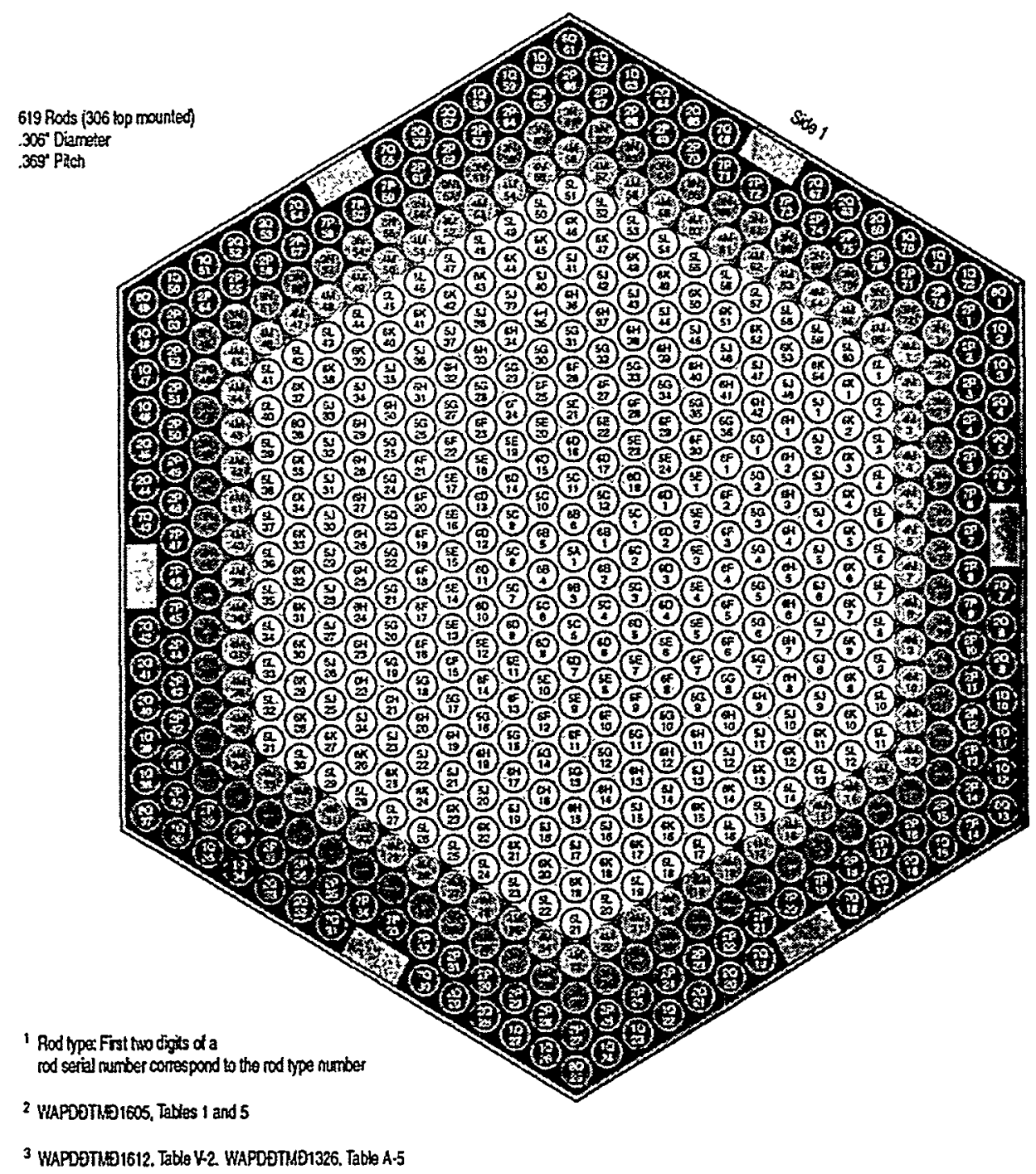

Figure 3-3. LAyout of Fuel Rods In a SEEd ASSEMBLY

[Ref. 14, P. 12] 


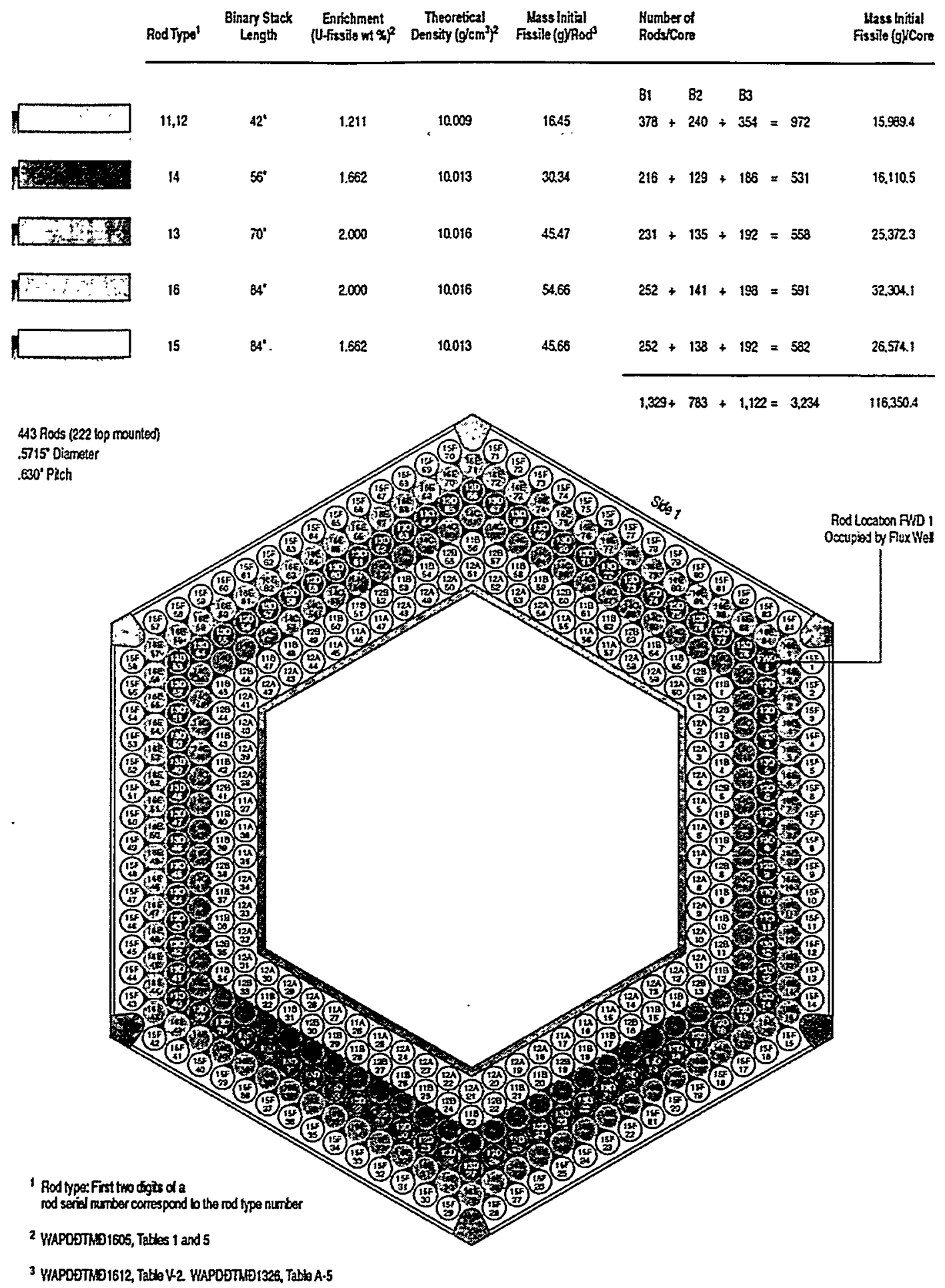

mowese

FiguRE 3-4. LAYOUT OF FUEL RODS IN A TYPE I BLANKET ASSEMBLY

[Ref. 14, p13] 


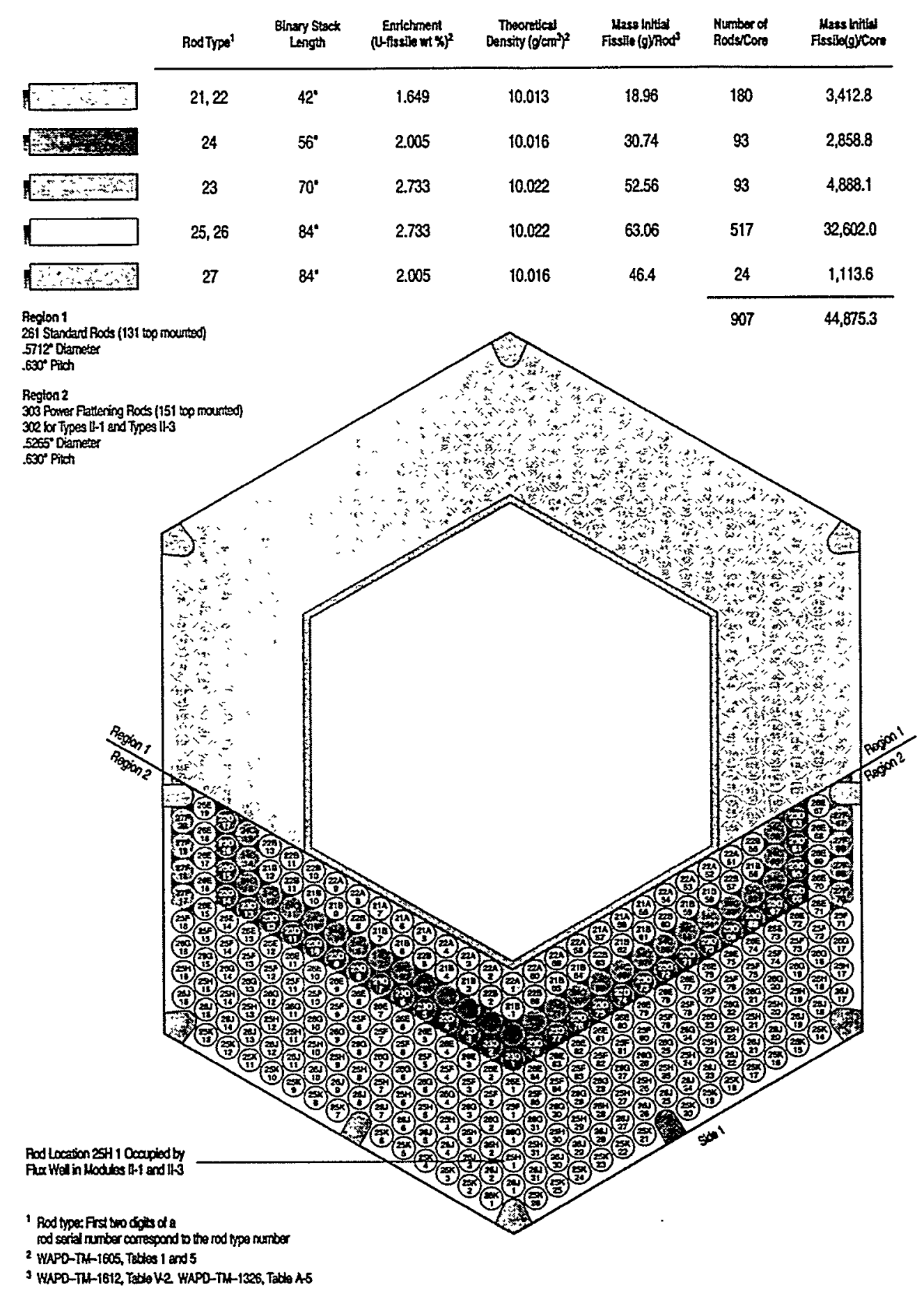

FIGURE 3-5. LAYOUT OF RODS IN A TYPE II BLANKET ASSEMBLY [Ref. 14, p15] 


\begin{tabular}{|c|c|c|c|c|c|c|c|}
\hline & RodType' & $\begin{array}{l}\text { Binery Stack } \\
\text { Length }\end{array}$ & 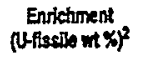 & $\begin{array}{c}\text { Theoretical } \\
\text { Density }\left(g / \mathrm{sm}^{2}\right)^{2}\end{array}$ & $\begin{array}{c}\text { Mass intitad } \\
\text { Fissice (g)firoos }\end{array}$ & $\begin{array}{l}\text { Rumber of } \\
\text { Rodscicors }\end{array}$ & 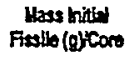 \\
\hline s & 21.22 & $42^{\circ}$ & 1.649 & 10.013 & 18.98 & 488 & 9,2146 \\
\hline Wh & 24 & $56^{\circ}$ & 2005 & 10.016 & 30.74 & 258 & $7,930.9$ \\
\hline$\because \because \cdots 3$ & 23 & $70^{\circ}$ & 2733 & 10.028 & 5256 & 254 & $13,875.8$ \\
\hline L & 25,26 & $84^{\circ}$ & 2733 & 10002 & 63.06 & 1,618 & $102,001.1$ \\
\hline $4: 8 \div$ & 27 & $84^{*}$ & 2005 & 10.018 & 46.4 & 48 & 2,272 \\
\hline & & & & & & 2,674 & 135.279 .6 \\
\hline
\end{tabular}

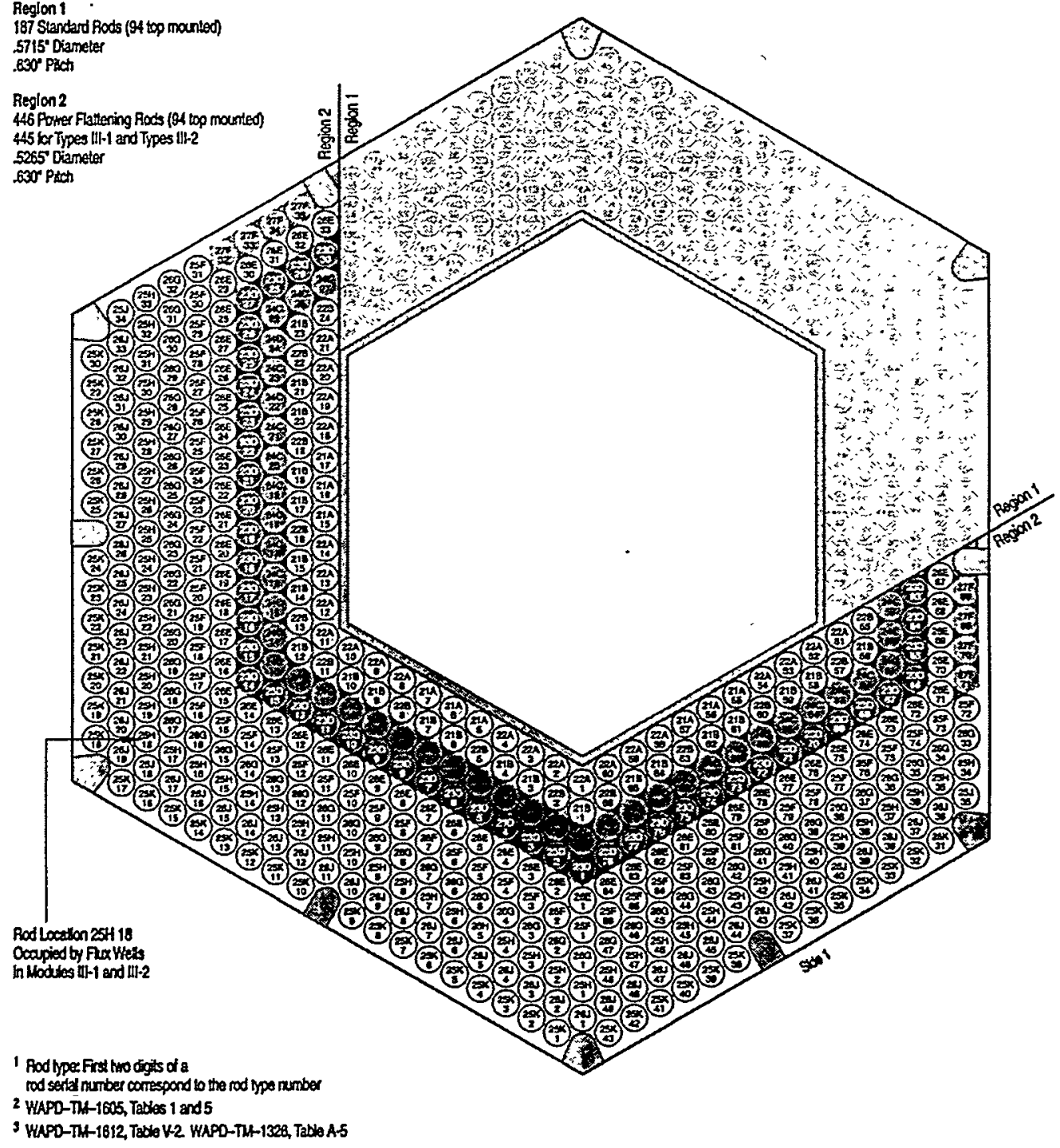

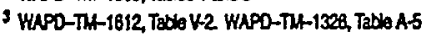

FIGURE 3-6. LAYOUT OF RODS IN A TYPE III BLANKET ASSEMBLY

[Ref. 14, p16] 


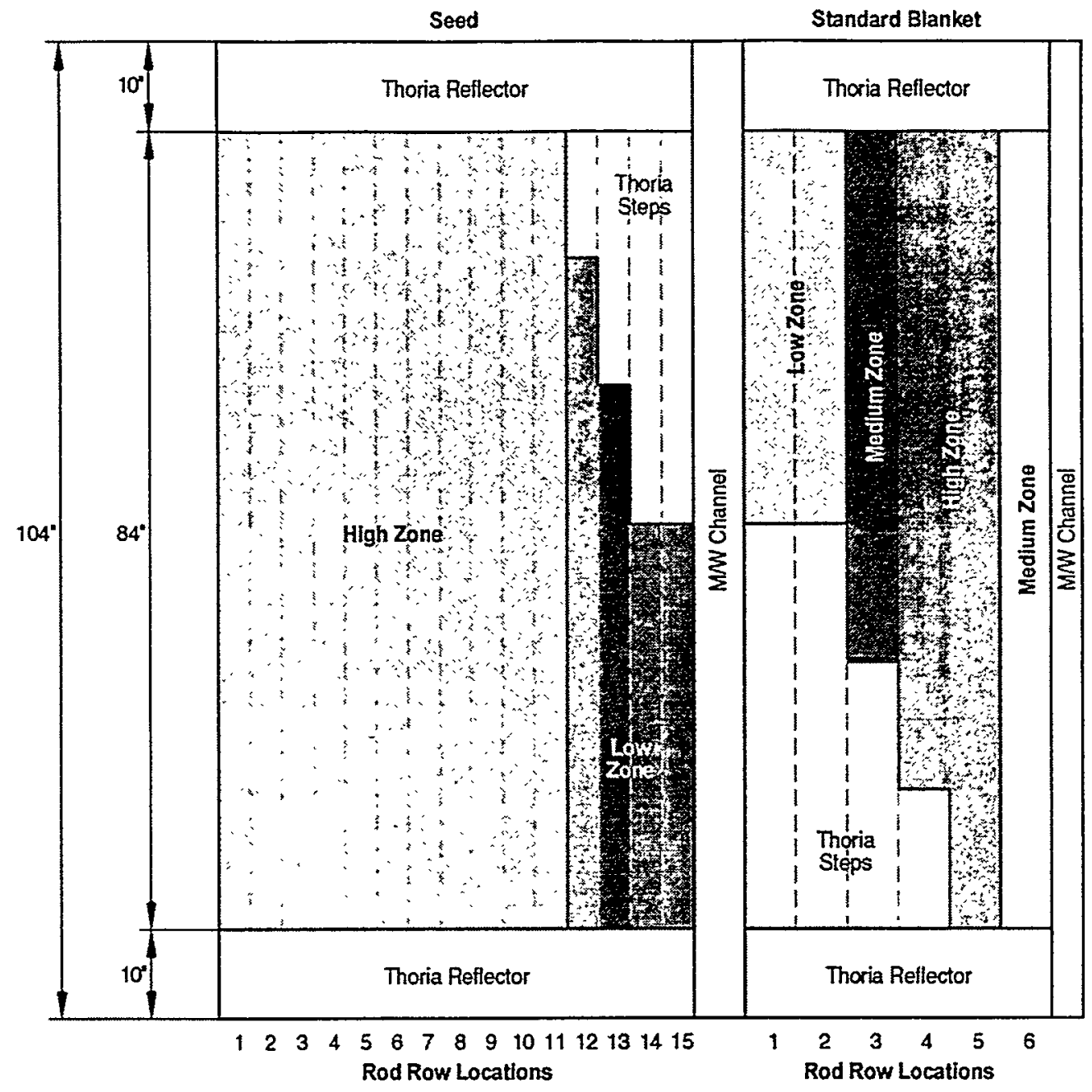

FiguRE 3-7. R-Z SCHEMATIC OF A TYPE I MODULE

[Ref. 14, p. 11] 


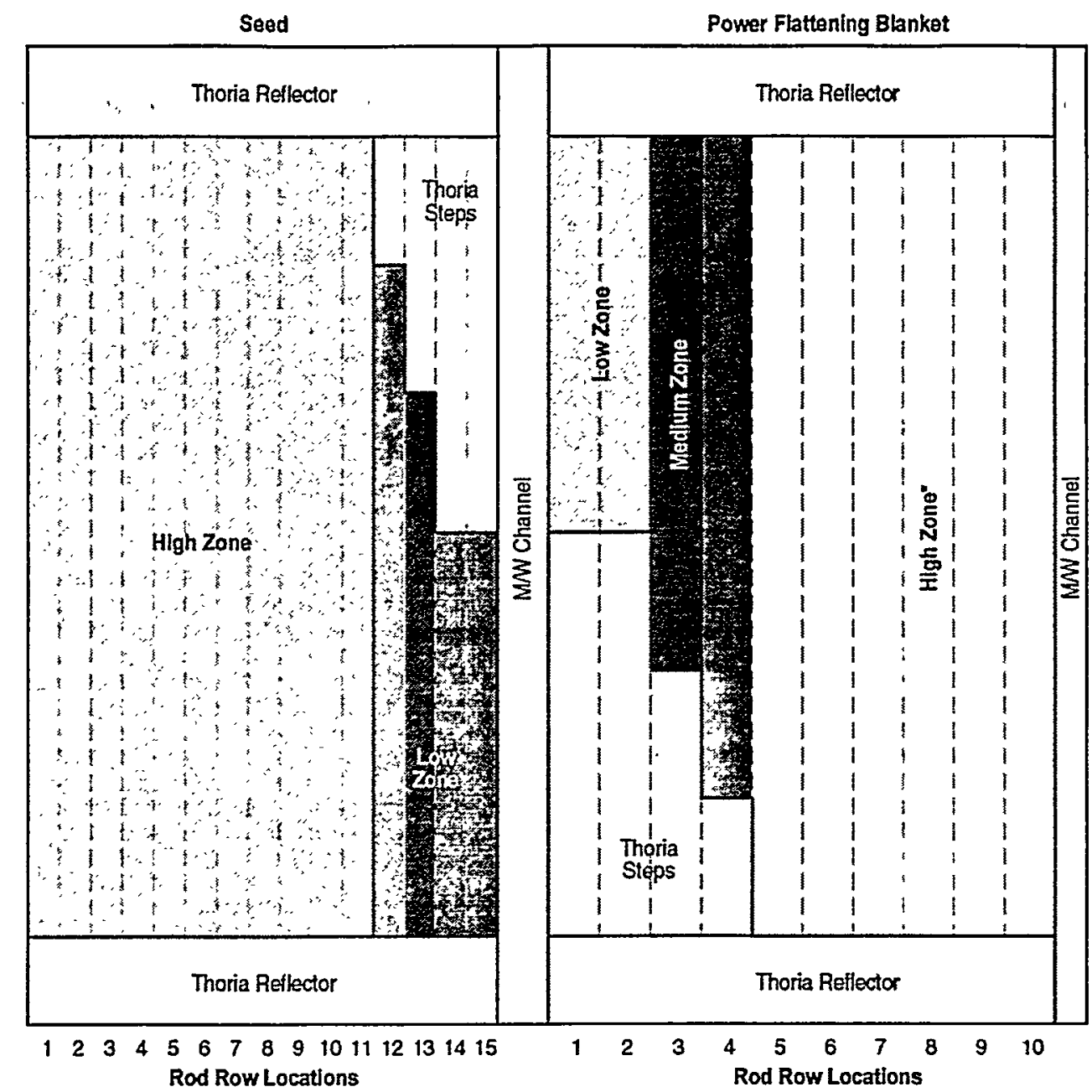

- Except for ejght Medium zone rods per module in row six (4 on esch side, along interface between modules).

FIGURE 3-8. R-Z SCHEMATIC OF POWER FLATTENING SIDES OF TYPE II AND TYPE III BLANKET MODULES [Ref. 14, p.14] 
After final shutdown, the 39 assemblies were shipped to the Expended Core Facility (ECF) at Naval Reactors Facility at the Idaho National Engineering and Environmental Laboratory (INEEL). At ECF, 12 of the 39 assemblies were partially dismantled and about 1,000 spent fuel rods were removed underwater from the assemblies for proof-of-breeding and fuel-performance testing [Ref. 11, pp. 27 and 37]. Some of the removed rods were kept at ECF; the rest were sent to Argonne National LaboratoryWest (ANL-W) in Idaho or ANL-East in Chicago for a variety of physical, chemical, and radiological examinations. All rods and rod sections remaining after the examinations were shipped back to ECF, where assemblies and loose rods were repackaged in liners for dry storage. In a series of shipments, the liners were transported from ECF to Idaho Nuclear Technology Engineering Center (INTEC), formerly the Idaho Chemical Processing Plant (ICPP). The 47 liners (39 modules, 7 containers of intact fuel rods, and 1 container of cut fuel rods) are stored in underground dry wells at the CPP-749 dry fuel storage facility in upright right circular liners with an outside diameter of 647.70-mm (25.5-in.) and length of 4008.12-mm (157.8-in.) [Ref. 11, p. 3-1].

The Fuel Receipt Criteria describe the 47 liners stored in CPP-749. The liners consisted of:

1. 27 "Type A" liners, which contain intact LWBR assemblies (i.e., assemblies from which no rods have been removed). Type $A$ liner interiors are configured to fit seed, standard and power flattening blanket, and reflector assemblies.

2. 12 "Type B" liners, which contain partially derodded assemblies. Derodding required sawing off the tops and bottoms of the assemblies.

3. 7 "Type C" liners, which contain intact spent fuel rods that have been removed from the assemblies that now occupy the Type B liners plus some unirradiated rods that were used for calibration of instruments during post-irradiation testing.

4. 1 "scrap can" liner, which contains sections and pieces of unirradiated rods and irradiated rods that had been cut up or punctured for testing purposes, as well as unirradiated rods that were used for calibration. There are at least 22 containers within the scrap can. Many of the rods in the scrap can have been run through a variety of tests, which may have altered their physical, chemical, or radiological properties. Some 260 to 275 test rods similar to the LWBR fuel rods are included in the scrap can liner.

The number of Type A and Type B liners for each module type are provided in Table 3-2. Number of rods are listed in Table 3-3. 
Table 3-2. Number of Type "A" and "B" liners per module type [Ref. 12, p.121)].

\begin{tabular}{|l|c|c|}
\hline & $\begin{array}{l}\text { Number of Type "A" Liners } \\
\text { (fully rodded module) }\end{array}$ & $\begin{array}{l}\text { Number of Type "B" Liners } \\
\text { (partially derodded module) }\end{array}$ \\
\hline Seed & 8 & 4 \\
\hline Type I Blanket* & 2 & 1 \\
\hline Type II Blanket* & 2 & 1 \\
\hline Type III Blanket* & 4 & 2 \\
\hline Type IV Reflector* & 6 & 3 \\
\hline Type V Reflector* & 5 & 1 \\
\hline
\end{tabular}

* See Figure 3-2 for layout/arrangement of the various assemblies in the core.

Fully-rodded blanket assemblies have had mounting hardware removed from the tops and bottoms; intact seed and reflector assemblies have had hardware removed from the tops only. The tops and bottoms of some assemblies were sawn off to free up fuel rods for removal. Stabilization clamps were required to equip the partially derodded assemblies for subsequent handling and storage [Ref. 12, Appendix A; Ref. 13, Figure 28, p. 61]. The stabilization clamps consisted of end caps to hold the rods . in place and full-length tie rods to hold the top and bottom end caps in place. Lugs to secure the tie rods to the end caps protruded from each face of the hexagonal seed assemblies. Records of weights of the stored assemblies reveal that the partially derodded assemblies with stabilization clamps weigh hundreds of pounds more than the intact ones. [Ref. 14, Table 6-3]

In addition to the 39 Type $A$ and $B$ liners listed above, there are seven Type $C$ liners and a liner containing scrapped rods. The scrapped rods include some that were generated during development of the LWBR rod design and remnant pieces from LWBR PIE tests. 
Table 3-3. Numbers of Fuel Rods and Assemblies in Storage

[Ref. 14, Table 6-1].

\begin{tabular}{|c|c|c|c|c|c|c|c|c|c|c|}
\hline \multirow{2}{*}{$\begin{array}{l}\text { Module } \\
\text { ID }\end{array}$} & \multirow{2}{*}{$\begin{array}{l}\text { Fuel Piece } \\
\text { Serial \# }\end{array}$} & \multirow[t]{2}{*}{ Liner\# } & \multirow{2}{*}{$\begin{array}{l}\text { Liner } \\
\text { Types }\end{array}$} & \multirow{2}{*}{$\begin{array}{l}\text { \#Rods } \\
\text { Initially }\end{array}$} & \multirow{2}{*}{$\begin{array}{l}\text { \#Rods in } \\
\text { "A" liner }\end{array}$} & \multirow{2}{*}{$\begin{array}{l}\text { \#Rods in } \\
\text { "C" liner }\end{array}$} & \multirow{2}{*}{$\begin{array}{l}\text { \# P08 } \\
\text { Rods }^{6}\end{array}$} & \multicolumn{2}{|c|}{ \# DE Samples ${ }^{7}$} & \multirow{2}{*}{$\begin{array}{l}\text { \#Should be } \\
\text { in "B" liners } \\
A-(C+E+F)\end{array}$} \\
\hline & & & & & & & & ANL-W & ANL-E & \\
\hline$S-1-1$ & L-BB01-04 & 15601 & B & 619 & & 42 & 33 & 4 & 5 & 568 \\
\hline$S-1-2$ & L-BB01-05 & 15602 & A & 619 & 619 & & & & & \\
\hline$S-1-3$ & L-BB01-06 & 15603 & A & 619 & 619 & & & & & \\
\hline S-2-1 & L-BB01-09 & 15604 & A & 619 & 619 & & & & & \\
\hline S-2-2 & L-BB01-10 & 15605 & A & 619 & 619 & & & & & \\
\hline$S-2-3$ & L-BB01-13 & 15606 & B & 619 & & 128 & 34 & & & 491 \\
\hline S-3-1 & L-BB01-07 & 15607 & B & 619 & & 43 & 34 & & & 576 \\
\hline S-3-2 & L-BB01-08 & 15608 & B & 619 & & 39 & 33 & & & 580 \\
\hline$S-3-3$ & L-BB01-12 & 15609 & A & 619 & 619 & & & & & \\
\hline S-3-4 & L-BB01-11 & 15610 & A & 619 & 619 & & & & & \\
\hline$S-3-5$ & L-BB01-14 & 15611 & A & 619 & 619 & & & & & \\
\hline$S-3-6$ & L-BB01-16 & 15612 & A & 619 & 619 & & & & & \\
\hline B-1-1 & L-GR01-01 & 15613 & $A$ & 442 & 442 & & & & & \\
\hline B-1-2 & L-GR01-02 & 15614 & A & 442 & 442 & . & & & & \\
\hline$B-1-3$ & L-GU51-01 & 15615 & B & 443 & & 45 & 36 & 3 & 4 & 391 \\
\hline B-2-1 & L-GS01-01 & 15616 & A & 563 & 563 & & & & & \\
\hline B-2-2 & L-GS22-01 ${ }^{1}$ & 15617 & $B$ & 564 & & 80 & 65 & 4 & & 480 \\
\hline$B-2-3$ & L-GS01-02 & 15618 & A & 563 & 563 & & & & & \\
\hline B-3-1 & L-GT01-01 & 15619 & $A$ & 632 & 632 & & & & & \\
\hline B-3-2 & L-GW52-01 & 15620 & $\mathrm{~B}$ & 632 & & 391 & 72 & & & 241 \\
\hline B-3-3 & L-GT01-03 & 15621 & A & 633 & 633 & & & & & \\
\hline$B-3-4$ & L-GT01-04 & 15622 & A & 633 & 633 & & & & & \\
\hline B-3-5 & L-GT01-05 & 15623 & A & 633 & 633 & & & & & \\
\hline B-3-6 & L-GT22-03 & 15624 & $B$ & 633 & & 78 & 75 & & 6 & 549 \\
\hline$R-4-1$ & L-RA01-06 & 15625 & A & 228 & 228 & & & & & \\
\hline$R-4-2$ & L-RA01-02 & 15626 & A & 228 & 228 & & & & & \\
\hline$R-4-3$ & L-RA01-10 & 15627 & B & 228 & & 30 & 27 & 1 & 2 & 195 \\
\hline$R-4-4$ & L-RA01-09 & 15628 & B & 228 & & 76 & 29 & & & 152 \\
\hline$R-4-5$ & L-RA01-07 & 15629 & A & 228 & 228 & & & & & \\
\hline$R-4-6$ & L-RA0.1-04 & 15630 & A & 228 & 228 & & & & & \\
\hline$R-4-7$ & L-RA01-05 & 15631 & A & 227 & 227 & & & & & \\
\hline$R-4-8$ & L-RA01-08 & 15632 & A & 228 & 228 & & & & & \\
\hline$R-4-9$ & L-RA01-03 & 15633 & B & 228 & & 57 & 28 & & & 171 \\
\hline$R-5-1$ & L-RB01-07 & 15634 & A & 166 & 166 & & & & & \\
\hline R-5-2 & L-RB01-04 & 15635 & A & 166 & 166 & & & & & \\
\hline$R-5-3$ & L-RB01-06 & 15636 & A & 166 & 166 & & & & & \\
\hline$R-5-4$ & L-RB01-08 & 15637 & B & 166 & & 37 & 34 & & & 129 \\
\hline$R-5-5$ & LRB01-03 $^{2}$ & 15638 & $A$ & 166 & 166 & & & & & \\
\hline \multirow[t]{2}{*}{$R-5-6$} & L-RB01-05 & 15639 & $A$ & 166 & 166 & & & & & \\
\hline & & & Total & 17288 & 11690 & 1046 & 500 & 12 & 17 & 4523 \\
\hline
\end{tabular}


Table 3-3. (cont'd)

\begin{tabular}{|c|c|c|c|c|c|c|c|c|c|}
\hline $\begin{array}{l}\text { Module } \\
\text { ID }\end{array}$ & $\begin{array}{l}\text { Fuel Piece } \\
\text { Serial \# }\end{array}$ & Liner \# & $\begin{array}{l}\text { Liner } \\
\text { Type3 }\end{array}$ & $\begin{array}{l}\text { \#Rods } \\
\text { Initially }\end{array}$ & $\begin{array}{l}\text { \#Rods } \\
\text { in " } A \text { " } \\
\text { liner }\end{array}$ & $\begin{array}{l}\text { \#Rods } \\
\text { in "C" } \\
\text { liner" }\end{array}$ & $\begin{array}{l}\text { \# P08 } \\
\text { Rods }\end{array}$ & \# DE Samples ${ }^{7}$ & $\begin{array}{l}\text { \#Should be in } \\
\text { " } B \text { "liners } A- \\
(C+E+F)\end{array}$ \\
\hline
\end{tabular}

$\begin{array}{llccc}\text { FR-B-1 } & \text { Blanket } & 15682 & \text { C } & 175 \\ \text { FR-B2 } & \text { Blanket } & 15684 & \text { C } & 144 \\ \text { FR-B3 } & \text { Blanket } & 15685 & \text { C } & 243 \\ \text { FR-B4 } & \text { Blanket } & 15687 & \text { C } & 62 \\ \text { FR-R1 } & \text { Reflector } & 15681 & \text { C } & 127 \\ \text { FR-R2 } & \text { Reflector } & 15683 & \text { C } & 80 \\ \text { FR-S1 } & \text { Seed } & 15686 & \mathrm{C} & 270 \\ & \text { 624sections } & 15718 & & 1101\end{array}$

${ }^{1}$ The technician actually stated that the serial number was L-G522-01 (mistaking the $S$ for a 5)

${ }^{2}$ The videotape $w /$ audio is the only documentation of the serial numbers; videotape in is SNF records @ INTEC (CPP-666).

Serial number does not appear on the shipping forms.

${ }^{3}$ Reference: Bolton, Christensen and Hallinan (1989). Final Safety Analysis Report. March1989. WIN-107-4.7A, Rev. 1.

${ }^{4}$ Reference: WAPD-TM-1326 Table A-17 for seed and blanket WAPD-TM-1 605 for reflector

One flux thimble in each of the following modules: 81-1, 81-2, 82-1, 82-3, R4-7.

${ }^{5}$ Part $B$ of Fuel Receipt Criteria lists the serial numbers of each rod in Type $C$ liners.

${ }^{6}$ Reference: WAPD-TM-1612 (Sep 1987) Figures V-2 through V-13. Note: number of rods

shown in figures differs from the number of rods accounted for in Table $V-i$ of same report.

${ }^{7}$ Number of rods destructively evaluated. ANL-W performed DE on 12 rods. ANL-E+A32 performed DE on 17 rods.

Table 3-4. Summary of Masses for Intact and Partially Derodded Assemblies from all Core Regions [Ref. 14, Table 6-3].

\begin{tabular}{|l|c|c|c|}
\hline \multirow{2}{*}{$\begin{array}{c}\text { Core } \\
\text { Region }\end{array}$} & \multirow{2}{*}{$\begin{array}{c}\text { Assembly } \\
\text { Type }\end{array}$} & $\begin{array}{c}\text { Intact } \\
\text { Assemblies }\end{array}$ & $\begin{array}{c}\text { Partially Derodded } \\
\text { Assemblies }\end{array}$ \\
\hline Seed & All & $750.2(1654)$ & $913.1(2013)$ \\
\hline Blanket & I & $1910.5(4212)$ & $2140.0(4718)$ \\
\hline Blanket & II & $2218.1(4890)$ & $2453.9(5410)$ \\
\hline Blanket & III & $2728.4(6015)^{\circ}$ & $2634.9(5809)$ \\
\hline Reflector & IV & $2237.6(4933)$ & $2358.7(5200)^{\circ}$ \\
\hline Reflector & V & $1827.1(4028)$ & $1906.9(4204)$ \\
\hline
\end{tabular}

"This value only appears only once. The two other listed weights of intact assemblies of this type are $2405.4 \mathrm{~kg}(5303 \mathrm{lb})$.

One of the partially derodded Type IV reflector assemblies has a listed weight

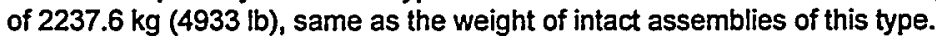
'Partially derodded assemblies have 'installed' fixtures that increase the weight of the individual assemblies. 


\subsubsection{Description of SNF from the Seed Region}

Two different enrichments of the same binary $\left(\mathrm{UO}_{2}-\mathrm{ThO}_{2}\right)$ matrix were used in seed rods. Axial and radial zoning of the fissile and fertile material were optimized for breeding. Axial zoning of the seed is shown in Figure 3-7, depicting the varying enrichments of the 619 rods [Ref. 14, Table 3-1] in each of the seed modules. Radial zoning of the fissile material of the seed is shown in Figure 3-3. Each seed was a movable assembly contained within a blanket assembly (Figure 3-1).

The 12 Seed assemblies together initially contained $198.59 \mathrm{~kg}$ of fissile material, with $61.28 \mathrm{~kg}$ ( $w t \%=4.337$; use as 'most conservative' fissile load) [Ref. 14, p. 23, Table 3-4] in rods of the lower fissile concentration (low zone) and $137.31 \mathrm{~kg}$ (wt\% $=5.202$; use as 'most conservative' fissile load) [Ref. 14, p. 23, Table 3-4] in rods of the higher fissile concentration (high zone).

\subsection{Fuel Pellets from the Seed Region}

Seed pellets were right circular cylinders, with chamfers (bevels) on both ends to ease loading into tubing, facilitate movement of the pellet stack in the tubing during power operation, and reduce pellet chipping during fabrication, rod handling, and power operation. The seed pellets had dished ends to reduce axial expansion of the stack. Fuel pellets in the seed region were smaller in diameter than pellets elsewhere in the core. Two types of binary pellets were used in the seed region (Table 3-5). The shorter binary pellets had a lower fissile concentration than the longer binary pellets. Thoria pellets, used near the top and bottom of the fuel stack, were shorter. A spring-bearing thoria pellet with only one dished end was used at the top of each fuel (pin) stack.

During fabrication, the pellets were sintered to a large fraction of their theoretical densities to ensure dimensional stability. The void fraction listed in Table 3-5 and elsewhere is defined as the fraction of the volume of a right circular cylindrical pellet of the nominal dimensions that is missing due to end dishes, chamfers, and pellet chips. 
Table 3-5. Characteristics of Pellets in the Seed Region [Ref. 14, p. 33; Ref. 5, Table 4 (except as noted)]

\begin{tabular}{|c|c|c|c|}
\hline \multirow[b]{2}{*}{ Property (units) } & \multicolumn{3}{|c|}{ Seed Region Enrichment Zone } \\
\hline & $\begin{array}{l}\text { High (5.202 wt\% } \\
\text { U-fissile enriched) }\end{array}$ & $\begin{array}{l}\text { Low (4.337 wt \% } \\
\text { U-fissile enriched) }\end{array}$ & $\mathrm{ThO}_{2}$ \\
\hline Diameter $^{\mathrm{a}}[\mathrm{mm} \text { (in) }]^{\prime}$ & $6.4008(0.2520)$ & $6.4008(0.2520)$ & $6.49224(0.2556)$ \\
\hline Diameter $^{b}$ [mm (in)] & $\begin{array}{c}6.4008 \pm .0127 \\
(0.252 \pm 0.0005)\end{array}$ & $\begin{array}{c}6.4008 \pm .0127 \\
(0.252 \pm 0.0005)\end{array}$ & $\begin{array}{c}6.4897 \pm .0127 \\
(0.2555 \pm .0005)\end{array}$ \\
\hline Length $^{a}[\mathrm{~mm} \text { (in) }]^{T}$ & $15.621(0.615)$ & $11.2776(0.444)$ & $13.462(0.530)$ \\
\hline Length $^{b}[\mathrm{~mm}$ (in)] & $\begin{array}{l}15.621 \pm .508 \\
(0.615 \pm .020)\end{array}$ & $\begin{array}{l}11.303 \pm .508 \\
(0.445 \pm .020)\end{array}$ & $\begin{array}{l}13.462 \pm .508 \\
(0.530 \pm .020)\end{array}$ \\
\hline $\begin{array}{l}\text { Taper or Chamfer Depth } \\
{[\mathrm{mm} \text { (in)] }}\end{array}$ & $\begin{array}{c}0.381 \pm 0.127 \\
(0.015 \pm 0.005)\end{array}$ & $\begin{array}{c}0.381 \pm 0.127 \\
(0.015 \pm 0.005)\end{array}$ & $\begin{array}{c}0.381 \pm 0.127 \\
(0.015 \pm 0.005)\end{array}$ \\
\hline $\begin{array}{l}\text { Taper or Chamfer Length } \\
\text { [mm (in)] }^{3}\end{array}$ & $\begin{array}{c}0.381 \pm 0.127 \\
(0.015 \pm 0.005)\end{array}$ & $\begin{array}{c}0.381 \pm 0.127 \\
(0.015 \pm 0.005)\end{array}$ & $\begin{array}{c}0.381 \pm 0.127 \\
(0.015 \pm 0.005)\end{array}$ \\
\hline $\begin{array}{l}\text { End Dish Spherical Radius } \\
\text { [mm (in)] }^{\circ}\end{array}$ & $9.144(0.360)$ & $9.144(0.360)$ & $7.5692(0.298)$ \\
\hline $\begin{array}{l}\text { End Shoulder Width } \\
\text { [mm (in)] }\end{array}$ & $\begin{array}{c}1.1684 \pm 0.20 \\
(0.046 \pm 0.008)\end{array}$ & $\begin{array}{c}1.1684 \pm 0.20 \\
(0.046 \pm 0.008)\end{array}$ & $\begin{array}{c}1.397 \pm 0.254 \\
(0.055 \pm 0.010)\end{array}$ \\
\hline $\begin{array}{l}\text { End Face Dish Depth } \\
\text { [mm (in)] }\end{array}$ & $\begin{array}{l}0.2286 \pm 0.0762 \\
(0.009 \pm 0.003)\end{array}$ & $\begin{array}{l}0.2286 \pm 0.0762 \\
(0.009 \pm 0.003)\end{array}$ & $\begin{array}{l}0.2286 \pm 0.0762 \\
(0.009 \pm 0.003)\end{array}$ \\
\hline $\begin{array}{l}\text { Void Fraction }{ }^{2} \text { (of chamfers, dishes, and } \\
\text { chip defects) }\end{array}$ & 0.01172 & 0.01704 & 0.01253 \\
\hline Percent Theoretical Density & 97.554 & 97.712 & 98.013 \\
\hline Theoretical Density $\left(\mathrm{g} / \mathrm{cm}^{3}\right)^{3}$ & 10.042 & 10.035 & 9.999 \\
\hline
\end{tabular}

${ }^{2}$ Average as built.

${ }^{\mathrm{b}}$ Design specification.

1. Ref. 14, Table 3-4; use as 'most consenvative' fissile loading

2. Ref. 2, Table 2

3. Ref. 5, p. 20 (Table 4)

\subsection{Fuel Rods from the Seed Region}

There were eight types of seed rods. Dimensions of the eight types are shown in Figure 3-9. Rods with odd type numbers were fixed to the bottom of the assembly, while even numbered rods were fixed at the top. The diameter of the mounting stems is not precisely known but historical documents imply that it does not exceed 5.7658-mm (0.227-in.) [Ref. 13, Fig. 5 and Ref. 9, Note 1 of Figures II-4, II-5, and II6]. The seamless cladding tubes were welded at both ends to solid end plugs of Zircaloy-4 [End-plug material is identified in Ref. 9, Table 5, p. 21]. Cladding dimensions are given in Table 3-8. The cladding tubes in the seed region were freestanding; that is, they were designed to withstand operating pressures and temperatures without collapsing onto the pellet stack. However, irradiation of the rods caused a reduction in diameter of 0.03 to $0.06-\mathrm{mm}$ (1.2 to 2.5 -mils) [Ref. 2, p. 119]. Within the tube and above the pellet stack there was a $254 \pm 2.54-\mathrm{mm}(10.0 \pm 0.1-\mathrm{in}$.) plenum at the top of the fuel stack to accommodate fission gases [Ref. 2, p. 50 (Fig. 13)]. The plenum housed an Inconel X-750 [Ref. 2, p. 21, Table 5] wire compression spring (Table 3-9). The approximate weights of unirradiated fuel rod components for all core regions are given in Table 3-10. 
Table 3-6. As-Built Characteristics of Seed Fuel Rods.

[Ref. 2, Fig. 3 (except as noted)]

\begin{tabular}{|c|c|c|c|c|c|}
\hline $\begin{array}{c}\text { Fuel } \\
\text { Rod } \\
\text { Type }\end{array}$ & $\begin{array}{c}\text { Number } \\
\text { per } \\
\text { Assem } \\
- \text { bly }^{\mathrm{a}}\end{array}$ & $\begin{array}{c}\text { Overall Length } \\
\text { [mm (in)] }\end{array}$ & $\begin{array}{c}\text { Fength of } \\
\text { Fixed-end } \\
\text { Plug } \\
\text { [mm (in)] }\end{array}$ & $\begin{array}{c}\text { Length of } \\
\text { Mounting } \\
\text { Stem } \\
\text { [mm (in)] }\end{array}$ & $\begin{array}{c}\text { Length of } \\
\text { Free-end } \\
\text { Plug } \\
\text { [mm (in)] }\end{array}$ \\
\hline 01 & 30 & $3023.108(119.02)$ & $52.578(2.07)$ & $60.96(2.40)$ & $19.05(0.75)$ \\
\hline 02 & 84 & $3023.108(119.02)$ & $44.958(1.77)$ & $60.96(2.40)$ & $26.67(1.05)$ \\
\hline 03 & 72 & $3026.156(119.14)$ & $52.578(2.07)$ & $64.008(2.52)$ & $19.05(0.75)$ \\
\hline 04 & 66 & $3026.156(119.14)$ & $44.958(1.77)$ & $64.008(2.52)$ & $26.67(1.05)$ \\
\hline 05 & 181 & $3029.458(119.27)$ & $52.578(2.07)$ & $67.31(2.65)$ & $19.05(0.75)$ \\
\hline 06 & 150 & $3029.458(119.27)$ & $44.958(1.77)$ & $67.31(2.65)$ & $26.67(1.05)$ \\
\hline 07 & 30 & $3006.598(118.37)$ & $52.578(2.07)$ & $44.45(1.75)$ & $19.05(0.75)$ \\
\hline 08 & 6 & $3006.598(118.37)$ & $44.958(1.77)$ & $44.45(1.75)$ & $26.67(1.05)$ \\
\hline
\end{tabular}

${ }^{2}$ Ref. 6, Fig. II-4

Table 3-7. Further As-Built Characteristics of Fuel Rods in the Seed Region

[Ref. 14, pgs 23-24]

\begin{tabular}{|l|c|c|c|}
\hline Rod Type & $\begin{array}{c}\text { Initial fissile } \\
\text { mass loading } \\
\text { (g/rod) }\end{array}$ & $\begin{array}{c}\text { Fissile Concentration of } \\
\text { the Binary Stack } \\
\text { (wt\% fissile) }\end{array}$ & $\begin{array}{c}\text { Length of } \\
\text { Binary Stack } \\
\text { [mm (in)] }\end{array}$ \\
\hline $01,02,07,08$ & 14.33 & 4.337 & $1066.8(42)$ \\
\hline 03 & 19.14 & 4.337 & $1422.4(56)$ \\
\hline 04 & 23.92 & 4.337 & $1778(70)$ \\
\hline 05,06 & 34.57 & 5.202 & $2133.6(84)$ \\
\hline
\end{tabular}

Weight percent fissile $(\mathrm{U}-233+\mathrm{U}-235) /\left(\mathrm{ThO}_{2}+\mathrm{UO}_{2}\right)$. Historical documents give conflicting values. The largest reported as-built values are listed here. The conflicting values, 4.327 and 5.195 , are less than $0.3 \%$ less.

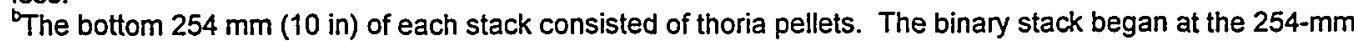
level. Because there were no binary shim pellets, the length of the binary stack may differ from rod to rod by up to one pellet length. Thoria pellets made up the rest of the stack above the binary stack. Total pellet stack length was $2635.25 \mathrm{~mm}$ (103.75 in).

Table 3-8. Average As-Built Cladding Dimensions for all Core Regions [Ref. 14, p.8]

\begin{tabular}{|l|c|c|}
\hline Core Region & $\begin{array}{c}\text { Outside Diameter } \\
{[\mathrm{mm} \text { (in)] }}\end{array}$ & $\begin{array}{c}\text { Thickness } \\
{[\mathrm{mm} \text { (in)] }}\end{array}$ \\
\hline Seed & $7.78002(0.3063)$ & $0.563118(0.02217)$ \\
\hline Standard Blanket & $14.52118(0.5717)$ & $0.713232(0.02808)$ \\
\hline Power Flattening Blanket & $13.39596(0.5274)$ & $0.671068(0.02642)$ \\
\hline Reflector & $21.14042(0.8323)$ & $1.06426(0.0419)$ \\
\hline
\end{tabular}

Table 3-9. Plenum Spring Dimensions for all Core Regions

[Spring dimensions are from Ref. 2, pp. 123-124, Tables 41 \& 42]

\begin{tabular}{|l|c|c|c|}
\hline \multicolumn{1}{|c|}{ Core Region } & $\begin{array}{c}\text { Number } \\
\text { of Coils }\end{array}$ & $\begin{array}{c}\text { Wire Diameter } \\
{[\mathrm{mm} \text { (in)] }}\end{array}$ & $\begin{array}{c}\text { Spring Diameter } \\
{[\mathrm{mm} \text { (in)] }}\end{array}$ \\
\hline Seed & 190 & $1.0795(0.0425)$ & $5.2578(0.207)$ \\
\hline Standard Blanket & 125 & $1.81102(0.0713)$ & $9.1694(0.361)$ \\
\hline Power Flattening Blanket & 135 & $1.66624(0.0656)$ & $8.4328(0.332)$ \\
\hline Reflector & 33 & $2.7686(0.109)$ & $13.3858(0.527)$ \\
\hline
\end{tabular}


Table 3-10. Estimated Masses of Unirradiated Fuel Rod Components for all Core Regions [company internal document, "Information package from Bettis to ANL LWBR-CE-POB", Table III-F.]

\begin{tabular}{|l|c|c|c|c|}
\hline \multirow{2}{*}{ Core Region } & \multicolumn{4}{|c|}{ Mass per Rod (kg) } \\
\cline { 2 - 5 } & $\begin{array}{c}\text { Fuel } \\
\text { Pellets }\end{array}$ & $\begin{array}{c}\text { Cladding } \\
\text { and End } \\
\text { Caps }\end{array}$ & $\begin{array}{c}\text { Internal } \\
\text { Hardware }\end{array}$ & Total \\
\hline Seed & 0.83 & 0.27 & 0.02 & 1.12 \\
\hline Standard Blanket & 3.38 & 0.69 & 0.14 & 4.21 \\
\hline Power Flattening Blanket & 2.85 & 0.59 & 0.12 & 3.56 \\
\hline Reflector & 6.94 & 1.47 & 0.12 & 8.53 \\
\hline
\end{tabular}

\subsection{Seed Modules}

There were twelve nominally identical seed modules. Key dimensions of the cross sections of the various types of fuel modules are given in Figure 3-11. Figure 3-3 depicts the radial zoning of the seed modules. The fuel rod in the center of a seed module occupies the first "row". Each successive hexagonal layer of rods wrapping around the central fuel rod forms another consecutively numbered row. Higher-enriched fuel occupied the central eleven rows of the seed assemblies, where the binary stack length was at its maximum. Lower-enriched fuel occupied the remaining four outer rows, which contained decreasing amounts of U-fissile with distance from the center due to shorter binary stack lengths.

Base plates of Inconel 600 alloy held the fuel rods in position axially [Ref. 12, p. 3]. Approximately half of the fuel rods were secured to the top base plate and the others were secured to the bottom base plate. The base plates were 38.1-mm (1.5-in.) thick and were perforated as shown in Figure 3-12 to accept the rod mounting stems and to allow the flow of cooling water [Ref. 12, p. 3 \& Fig. 1]. Average as-built fissile masses in assemblies from all core regions are given in Table 3-11. The seed assembly with the maximum fissile loading contained the BOL quantities of thorium and isotopes of uranium as shown in Table 3-12.

Table 3-11. Average As-Built Fissile Loading of Assemblies from All Core Regions [Ref. 14, p 43]

\begin{tabular}{|c|c|c|c|}
\hline \multirow[b]{2}{*}{ Core Region } & \multicolumn{3}{|c|}{$\begin{array}{l}\text { Average As-Built Fissile Loading }^{\mathrm{a}} \\
(\mathrm{kg})\end{array}$} \\
\hline & Type I & Type II & Type III \\
\hline Seed & 16.53 & 16.55 & 16.56 \\
\hline Blanket & 16.18 & 25.00 & 29.85 \\
\hline
\end{tabular}


Table 3-12. Composition of the Seed Assembly with Maximum Fissile Loading [Ref. 14, Table III-1, p. 21 (maximum composite of all seed assemblies)]

\begin{tabular}{|c|c|}
\hline Nuclide & $\begin{array}{c}\text { Mass } \\
(\mathbf{g})\end{array}$ \\
\hline${ }^{322} \mathrm{Th}$ & $434.09 \mathrm{kgs}$ \\
\hline${ }^{232} \mathrm{U}$ & 0.12 \\
\hline${ }^{233} \mathrm{U}$ & 16568.70 \\
\hline${ }^{234} \mathrm{U}$ & 215.20 \\
\hline${ }^{235} \mathrm{U}$ & 11.49 \\
\hline${ }^{236} \mathrm{U}$ & 2.49 \\
\hline${ }^{238} \mathrm{U}$ & 45.85 \\
\hline${ }^{230} \mathrm{U}+{ }^{235} \mathrm{U}$ & 16580.19 \\
\hline
\end{tabular}

A nominal 9.36244-mm (0.3686-in) center-to-center spacing between fuel rods was maintained along the length of each seed assembly by nine stainless steel (AM-350) grids. The uppermost grid was entirely above the fuel, and half of the lowermost grid was below the fuel. Leaving out the portions of the grids above and below pellet stacks, the grids displaced $2.130 \mathrm{~cm}^{3}\left(0.130 \mathrm{in}^{3}\right)$ of cooling water for each fuel rod in the seed assemblies. Grids in the seed region weighed, on average, $1542 \mathrm{~g}$ each grid, while the assembly with the most massive grids had an average grid mass of $1557 \mathrm{~g}$. [Ref. 6, Table A14]

The outer support shell of the seed assemblies was a 2.032-mm (0.080-in) thick hexagonal shell of Zircaloy-4 [Ref. 14, p. 39]. The length of the support shell may be taken to be 3302-mm (130.00-in.), though this length includes that of the bottom cover plate. The distance between the inner surfaces of the top and bottom base plates was 3009.9-mm (118.500-in.). The distance between the bottom of the assembly and the inner surface of the bottom base plate was greater than 111.76-mm (4.4-in.) and less than 254-mm (10-in.); halfway between the bounds is a reasonable approximation [Westinghouse Bettis Atomic Power Laboratory Drawing. LWBR TR-19.4. "Product Dwg Seed Fuel Assembly." July 19, 1998. 927J464]. For top- and bottom-mounted fuel rods, the distance to the bottom of the pellet stack from the inner surface of the bottom base plate is $52.578 \mathrm{~mm}$ (2.07-in.) as shown in Fig. 3-9. Therefore, the total distance between the bottom of the fuel assembly and the bottom of the fuel stack is approximately $235 \mathrm{~mm}$. The maximum corner-to-corner width of the seed assemblies shown in Figure 3-10 was 281.432-mm (11.08-in) [Ref. 14, p. 39].

Hardware removed from the seed assembly tops included the support shaft, the uppermost hexagonal portion of the assembly, the cover plate, and the top base plate bolts (Figure 3-11). The removal of mounting hardware from the assemblies necessitated the attachment of shipping plates at the tops so that the assemblies could be picked up [Ref. 15, Figures $2,10, \& 16]$. The shipping plates on the seed assemblies consist of 50.8-mm (2.0-in) thick rings of Type 304 stainless steel with inner diameter 155.956-mm (6.140-in.) and outer diameter 244.5512-mm (9.628-in.). There are a number of holes and recessions in the shipping plates. Of the many holes and recessions, 9 holes bear mentioning: 6 holes 14.224-mm (0.560-in.) in diameter and 3 holes 25.4-mm (1.00-in.) in diameter. Records of the total 


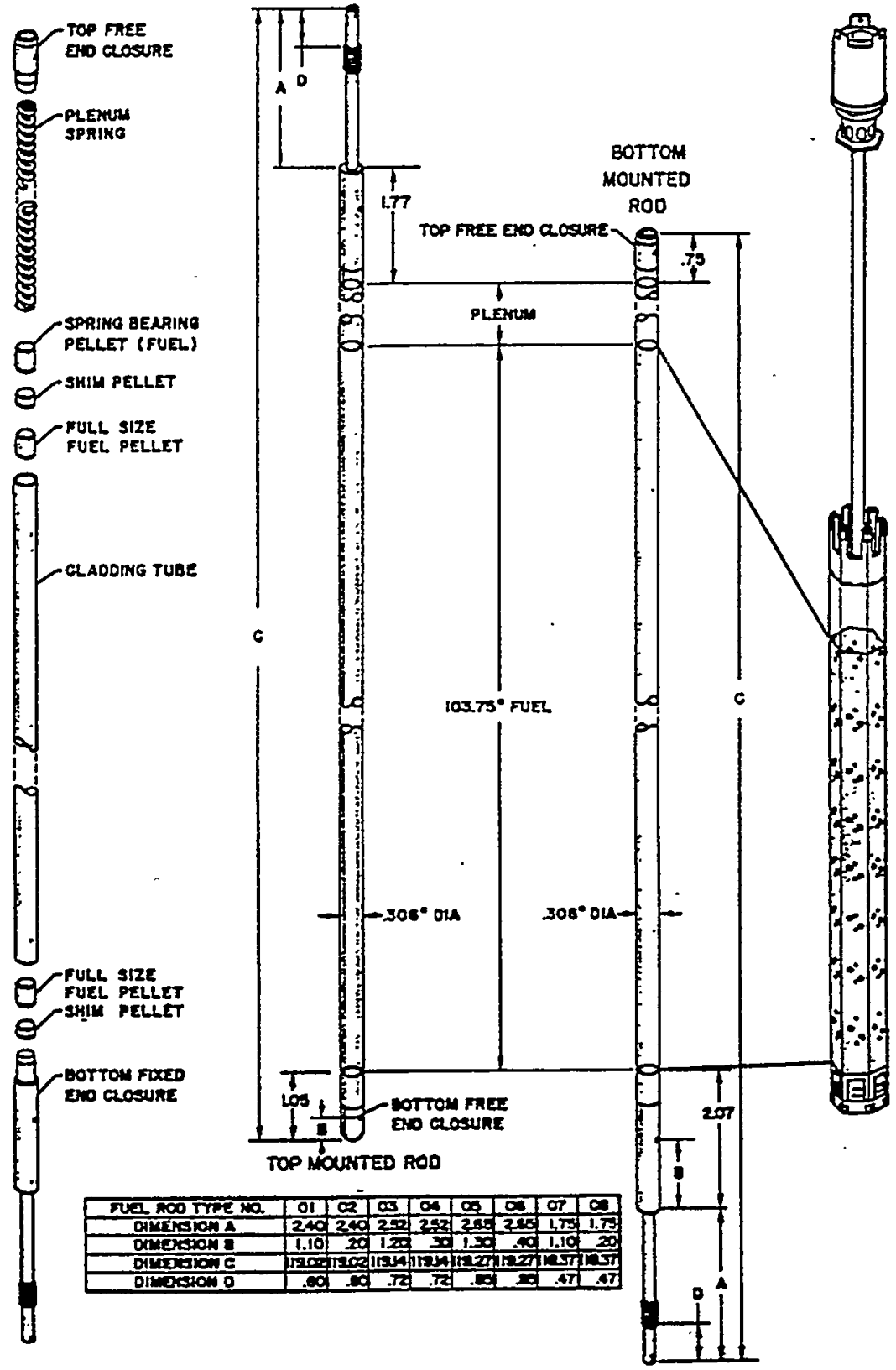

Figure 3-9. SCHEMATIC REPRESENTATION OF SEED Fuel RodS [Ref. 14, Fig. 3-9] 


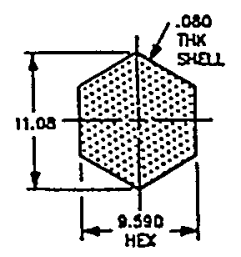

SEED

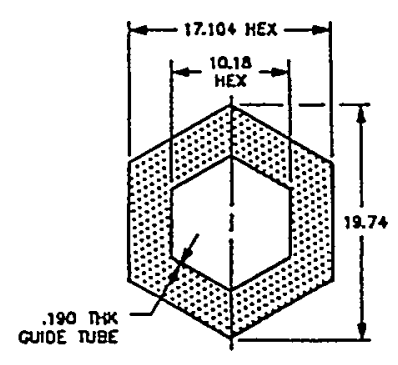

QLANKET

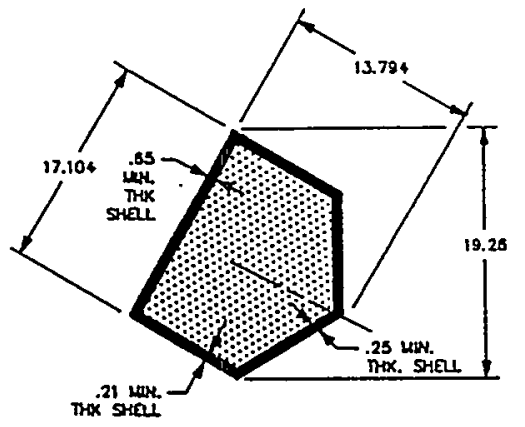

REFLECTOR
TYPE II

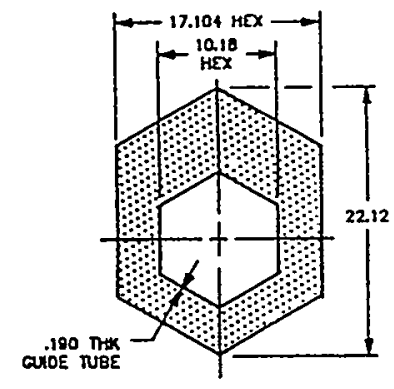

BLANKET
MPE II

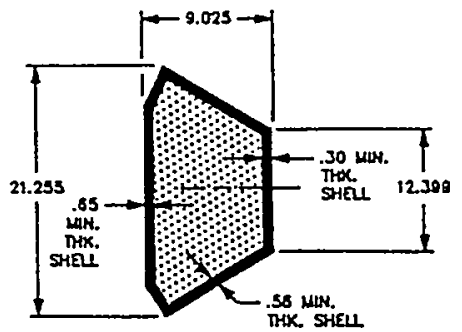

REFLECTOR TYPE I

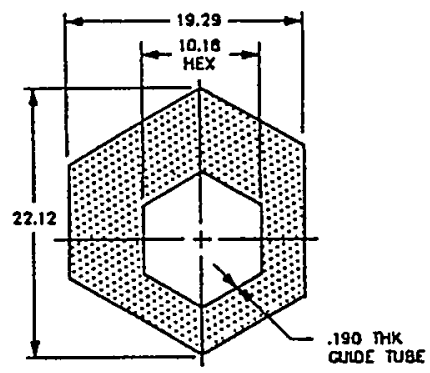

BLANKET
TYPE III

Figure 3-10. Cross Sectional Dimensions IN INCHES OF THE Fuel ASSEMBLIES [Ref. 14, p. 39]

weights of intact assemblies in storage are available (Table 3-4). The intact assemblies, including attached shipping plates, are between 3302-mm (130-in.) and 3327.4-mm (131-in.) long, allowing for the 25.4-mm (1-in.) maximum extent that the studs and nuts for attaching the shipping plates were allowed to protrude beyond the Zircaloy-4 support shell [Ref. 15, pp. 18-20 and Westinghouse Bettis Atomic Power Laboratory Drawing. LWBR TR-19.4. "Product Dwg Seed Fuel Assembly." July 19, 1998. 927J464]. 


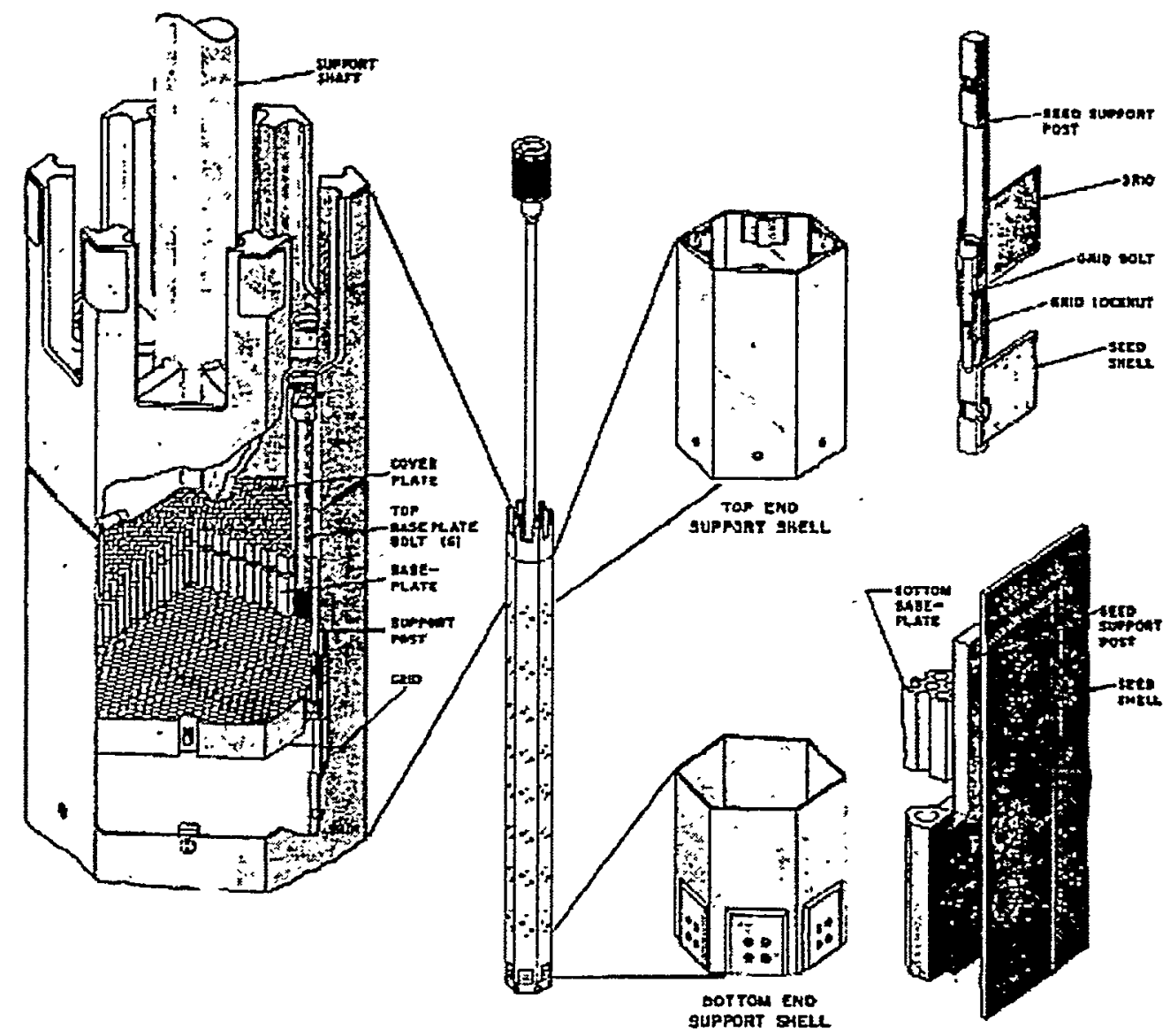

Figure 3-11. SEEd AsSEMBly CONSTRUCTION

[Ref. 12, p. 4]

\subsubsection{Description of SNF from the Blanket Regions}

Three different binary mixtures were used to fabricate the fuel in the Standard Blanket Region (1.214, 1.668 , and $2.005 \mathrm{wt} \%$ fissile) [Ref. 6, Table II-2], and three different binary mixtures were used to fabricate the fuel in the Power-Flattening Blanket Region (1.654, 2.009, and $2.739 \mathrm{wt} \%$ fissile) [Ref. 6, Table II-2], resulting in six enrichments of binary blanket pellets. As in the Seed Region, the tops and bottoms of the fuel rods were stacked with $\mathrm{ThO}_{2}$ pellets, and between the two fertile end stacks was a variable length binary $\mathrm{ThO}_{2}-\mathrm{UO}_{2}$ stack. The axial zoning for the Type I blanket modules and the standard blanket sides of the Type II and Type III blanket modules is shown in Figure 3-7, and in Figure 3-8 for the power-flattening sides of the Type II and Type III modules. 


\subsection{Fuel Pellets from the Blanket Regions}

There were four types of fuel pellets manufactured for the standard blanket rods, and four types manufactured for the power-flattening blanket rods. A distinction is made here between a chamfer, which extends roughly the same distance axially and radially, and a taper, which extends much farther along the axial direction. The binary pellets were right circular cylinders that were tapered and dished on both ends to discourage ridging of cladding due to pellet hour-glassing and to reduce axial expansion of the fuel (pin) stack. The thoria pellets were chamfered and dished on both ends. Pellets in the blanket regions were roughly twice as large in diameter as the seed pellets (Table 3-13 and Table 3-14). Short shim pellets of thoria were used near the top and bottom of the fuel stack to make up the desired stack length. A spring-bearing thoria pellet with only one dished end was used at the top of the fuel stack [Ref. 14, p.34].

Table 3-13. Characteristics of Pellets in the Standard Blanket [Ref. 14, p. 33 (except as noted)]

\begin{tabular}{|c|c|c|c|c|}
\hline \multirow[b]{2}{*}{ Property (units) } & \multicolumn{4}{|c|}{ Standard Blanket Region Enrichment Zone } \\
\hline & $\begin{array}{l}\text { High (2.005 } \\
{\text { wt } \%)^{1}}^{1}\end{array}$ & $\begin{array}{c}\text { Medium (1.668 } \\
\text { wt \%) }\end{array}$ & $\begin{array}{c}\text { Low (1.214 } \\
{\text { wt\% } \%)^{1}}\end{array}$ & Thoria \\
\hline Diameter $^{\mathrm{a}}[\mathrm{mm} \text { (in) }]^{1}$ & $12.9667(0.5105)$ & $12.9667(0.5105)$ & $12.9667(0.5105)$ & $12.9667(0.5105)$ \\
\hline Diameter $^{\mathrm{b}}[\mathrm{mm}$ (in)] & $\begin{array}{l}12.9667 \pm .0127 \\
(0.5105 \pm .0005)\end{array}$ & $\begin{array}{l}12.9667 \pm .0127 \\
(0.5105 \pm .0005)\end{array}$ & $\begin{array}{l}12.9667 \pm .0127 \\
(0.5105 \pm .0005)\end{array}$ & $\begin{array}{l}12.9667 \pm .0127 \\
(0.5105 \pm .0005)\end{array}$ \\
\hline Length $^{a}[\mathrm{~mm} \text { (in) }]^{\top}$ & $19.939(0.785)$ & $22.0472(0.868)$ & $13.487(0.531)$ & $15.6464(0.616)$ \\
\hline Length $^{\mathrm{b}}[\mathrm{mm}(\mathrm{in})]$ & $\begin{array}{l}19.939 \pm .508 \\
(0.785 \pm .020)\end{array}$ & $\begin{array}{l}22.098 \pm .508 \\
(0.870 \pm .020)\end{array}$ & $\begin{array}{l}13.462 \pm .508 \\
(0.530 \pm .020)\end{array}$ & $\begin{array}{l}15.621 \pm .508 \\
(0.615 \pm .020)\end{array}$ \\
\hline $\begin{array}{l}\text { Taper or Chamfer Depth } \\
\text { [mm (in)] }{ }^{3}\end{array}$ & $\begin{array}{c}0.0762 \pm 0.0508 \\
(0.003 \pm 0.002)\end{array}$ & $\begin{array}{l}0.0762 \pm 0.0508 \\
(0.003 \pm 0.002)\end{array}$ & $\begin{array}{l}0.0762 \pm 0.0508 \\
(0.003 \pm 0.002)\end{array}$ & $\begin{array}{l}0.1524 \pm 0.1016 \\
(0.006 \pm 0.004)\end{array}$ \\
\hline $\begin{array}{l}\text { Taper or Chamfer Length } \\
{[\mathrm{mm}(\mathrm{in})]^{3}}\end{array}$ & $\begin{array}{c}3.81 \pm 1.27 \\
(0.150 \pm 0.050)\end{array}$ & $\begin{array}{c}3.81 \pm 1.27 \\
(0.150 \pm 0.050)\end{array}$ & $\begin{array}{c}3.81 \pm 1.27 \\
(0.150 \pm 0.050)\end{array}$ & $\begin{array}{c}0.1524 \pm 0.1016 \\
(0.006 \pm 0.004)\end{array}$ \\
\hline $\begin{array}{l}\text { End Dish Spherical Radius }{ }^{-} \\
\text {[mm (in)] }^{2}\end{array}$ & $\begin{array}{l}36.5506 \\
(1.439)\end{array}$ & $\begin{array}{l}36.5506 \\
(1.439) \\
\end{array}$ & $\begin{array}{l}36.5506 \\
(1.439) \\
\end{array}$ & $\begin{array}{l}36.5506 \\
(1.439) \\
\end{array}$ \\
\hline $\begin{array}{l}\text { End Shoulder Width } \\
\text { [mm (in)] }\end{array}$ & $\begin{array}{c}1.397 \pm 0.381 \\
(0.055 \pm 0.015)\end{array}$ & $\begin{array}{c}1.397 \pm 0.381 \\
(0.055 \pm 0.015)\end{array}$ & $\begin{array}{c}1.397 \pm 0.381 \\
(0.055 \pm 0.015)\end{array}$ & $\begin{array}{c}1.397 \pm 0.381 \\
(0.055 \pm 0.015) \\
\end{array}$ \\
\hline $\begin{array}{l}\text { End Face Dish Depth } \\
\text { [mm (in)] }\end{array}$ & $\begin{array}{l}0.3556 \pm 0.1016 \\
(0.014 \pm 0.004)\end{array}$ & $\begin{array}{l}0.3556 \pm 0.1016 \\
(0.014 \pm 0.004)\end{array}$ & $\begin{array}{l}0.3556 \pm 0.1016 \\
(0.014 \pm 0.004)\end{array}$ & $\begin{array}{c}0.3556 \pm 0.1016 \\
(0.014 \pm 0.004)\end{array}$ \\
\hline $\begin{array}{l}\text { Void Fraction } \text { (of chamfers, dishes, } \\
\text { and chip defects) }\end{array}$ & 0.01600 & 0.01335 & 0.02494 & 0.01399 \\
\hline Percent Theoretical Density ${ }^{\text {as }}$ & 98.115 & 98.224 & 98.608 & 97.796 \\
\hline Theoretical Density $\left(\mathrm{g} / \mathrm{cm}^{3}\right)^{3}$ & 10.016 & 10.013 & 10.009 & 9.999 \\
\hline
\end{tabular}

${ }^{a}$ Average as built.

Design specification.

1. Ref. 14, Table 3-4; use as 'most conservative' fissile loading

2. Ref. 2, Table 2

3. Ref. 5, p. 20 (Table 4) 
Table 3-14. Characteristics of Pellets in the Power Flattening Blanket [Ref. 14, p. 33 (except as noted)]

\begin{tabular}{|c|c|c|c|c|}
\hline \multirow[b]{2}{*}{ Property (units) } & \multicolumn{4}{|c|}{ Power-Flattening Blanket Region Enrichment Zone } \\
\hline & High $(2.739 w t \%)^{1}$ & $\begin{array}{l}\text { Medium }(2.009 \\
\text { wt } \%)^{1}\end{array}$ & $\begin{array}{c}\text { Low (1.654 } \\
\text { wt\%) }\end{array}$ & Thoria \\
\hline Diameter ${ }^{\sigma}\left[\mathrm{mm}\right.$ (in)] ${ }^{T}$ & $11.9278(0.4696)$ & $11.9253(0.4695)$ & $11.9253(0.4695)$ & $11.9278(0.4696)$ \\
\hline Diameter $^{b}$ [mm (in)] & $\begin{array}{l}11.9253 \pm .0127 \\
(0.4695 \pm .0005)\end{array}$ & $\begin{array}{l}11.9253 \pm .0127 \\
(0.4695 \pm .0005)\end{array}$ & $\begin{array}{l}11.9253 \pm .0127 \\
(0.4695 \pm .0005)\end{array}$ & $\begin{array}{l}11.9253 \pm .0127 \\
(0.4695 \pm .0005)\end{array}$ \\
\hline Length $^{\mathrm{a}}[\mathrm{mm}$ (in)] & $17.8054(0.701)$ & $19.9644(0.786)$ & $22.098(0.870)$ & $11.3538(0.447)$ \\
\hline Length $^{\mathrm{b}}[\mathrm{mm}$ (in)] & $\begin{array}{c}17.78 \pm .508 \\
(0.700 \pm .020)\end{array}$ & $\begin{array}{l}19.939 \pm .508 \\
(0.785 \pm .020)\end{array}$ & $\begin{array}{l}22.098 \pm .508 \\
(0.870 \pm .020)\end{array}$ & $\begin{array}{l}11.303 \pm .508 \\
(0.445 \pm .020)\end{array}$ \\
\hline $\begin{array}{l}\text { Taper or Chamfer Depth } \\
\text { [mm (in)] }\end{array}$ & $\begin{array}{l}0.06096 \pm .03556 \\
(0.0024 \pm 0.0014)\end{array}$ & $\begin{array}{l}0.06096 \pm .03556 \\
(0.0024 \pm 0.0014)\end{array}$ & $\begin{array}{l}0.06096 \pm .03556 \\
(0.0024 \pm 0.0014)\end{array}$ & $\begin{array}{l}0.1524 \pm 0.1016 \\
(0.006 \pm 0.004)\end{array}$ \\
\hline $\begin{array}{l}\text { Taper or Chamfer Length } \\
{\left[\mathrm{mm} \text { (in)] }{ }^{3}\right.}\end{array}$ & $\begin{array}{c}3.81 \pm 1.27 \\
(0.150 \pm 0.050)\end{array}$ & $\begin{array}{c}3.81 \pm 1.27 \\
(0.150 \pm 0.050)\end{array}$ & $\begin{array}{c}3.81 \pm 1.27 \\
(0.150 \pm 0.050)\end{array}$ & $\begin{array}{l}0.1524 \pm 0.1016 \\
(0.006 \pm 0.004)\end{array}$ \\
\hline $\begin{array}{l}\text { End Dish Spherical Radius }{ }^{\circ} \\
{[\mathrm{mm} \text { (in)] }}\end{array}$ & $\begin{array}{l}29.4894 \\
(1.161)\end{array}$ & $\begin{array}{l}29.4894 \\
(1.161)\end{array}$ & $\begin{array}{l}29.4894 \\
(1.161)\end{array}$ & $\begin{array}{l}29.4894 \\
(1.160)\end{array}$ \\
\hline $\begin{array}{l}\text { End Shoulder Width } \\
\text { [mm (in)] }\end{array}$ & $\begin{array}{c}1.397 \pm 0.381 \\
(0.055 \pm 0.015)\end{array}$ & $\begin{array}{c}1.397 \pm 0.381 \\
(0.055 \pm 0.015)\end{array}$ & $\begin{array}{c}1.397 \pm 0.381 \\
(0.055 \pm 0.015)\end{array}$ & $\begin{array}{c}1.397 \pm 0.254 \\
(0.055 \pm 0.010)\end{array}$ \\
\hline $\begin{array}{l}\text { End Face Dish Depth } \\
\text { [mm (in)] }\end{array}$ & $\begin{array}{c}0.3556 \pm 0.1016 \\
(0.014 \pm 0.004) \\
\end{array}$ & $\begin{array}{l}0.3556 \pm 0.1016 \\
(0.014 \pm 0.004)\end{array}$ & $\begin{array}{l}0.3556 \pm 0.1016 \\
(0.014 \pm 0.004)\end{array}$ & $\begin{array}{c}0.3556 \pm 0.1016 \\
(0.014 \pm 0.004)\end{array}$ \\
\hline $\begin{array}{l}\text { Void Fraction }{ }^{a} \text { (of chamfers, } \\
\text { dishes, and chip defects) }\end{array}$ & 0.01578 & 0.01753 & 0.01998 & 0.01966 \\
\hline $\begin{array}{l}\text { Percent Theoretical } \\
\text { Density }\end{array}$ & 97.906 & 98.041 & 98.034 & 98.057 \\
\hline $\begin{array}{l}\text { Theoretical Density } \\
\left(\mathrm{g} / \mathrm{cm}^{3}\right)^{3}\end{array}$ & 10.022 & 10.016 & 10.013 & 9.999 \\
\hline
\end{tabular}

Average as built.

Design specification.

1. Ref. 14 , Table $3-4$; use as 'most conservative' fissile loading

2. Ref. 2, Table 2

3. Ref. 5, p. 20 (Table 4)

\subsection{Fuel Rods from the Blanket Regions}

There were 13 types of blanket rods (Figure 3-12). The first digit of the rod type number indicates whether a rod is a standard blanket rod (Types 11 through 16) or a power flattening blanket rod (Types 21 through 27). Rods with even type numbers were fixed to the tops of the assemblies; odd numbered rods were fixed to the bottoms of the assemblies. As-built characteristics of the Blanket Region fuel rods are given in Tables 3-14 \& 3-15. The diameter of the mounting stems is not precisely known but historical documents imply that it does not exceed the value given in Table 3-16 [Ref. 12, Fig. 5 and Ref. 9, Note 1 of Figures II-4, II-5, and II-6). The seamless cladding tubes were welded at both ends to solid end plugs of Zircaloy-4 (Table 3-16). Cladding inner and outer diameters are given in Table 3-8. The cladding tubes in the blanket regions were not freestanding; that is, they were not designed to withstand operating pressures and temperatures without collapsing on the pellet stack. Within the tube and above the pellet stack there was a plenum at the top of the fuel stack to accommodate gaseous fission product. The plenum housed an Inconel X-750 wire compression spring (Table 3-9) and a support sleeve of seamless Type 348 stainless steel tubing [support-sleeve material is identified in Ref. 2, Table 5, p. 21]. The spring discouraged the formation of gaps between pellets while the support sleeve prevented collapse of the cladding against the compression spring. 
Table 3-15. Characteristics of Fuel Rods in the Blanket Regions [Ref. 14, pgs. 13, 15, \&30 (except as noted)]

\begin{tabular}{|c|c|c|c|c|c|}
\hline $\begin{array}{l}\text { Rod } \\
\text { Type }\end{array}$ & $\begin{array}{l}\text { Overall } \\
\text { Length } \\
\text { [mm (in)] }\end{array}$ & $\begin{array}{l}\text { Length of } \\
\text { Mounting } \\
\text { Stem } \\
\text { [mm (in)] }\end{array}$ & $\begin{array}{l}\text { Length of } \\
\text { Binary } \\
\text { Stack } \\
\text { [mm (in) }]^{1}\end{array}$ & $\begin{array}{c}\text { Fissile } \\
\text { Concentration } \\
\text { of Binary } \\
\text { Stack } \\
\text { (wt\% fissile) }\end{array}$ & $\begin{array}{c}\text { Initial Fissile } \\
\text { Mass } \\
\text { Loading } \\
\text { (g/rod) }\end{array}$ \\
\hline 11 & $3096.26(121.9)$ & $107.442(4.23)$ & $1066.8(42)$ & 1.214 & 16.45 \\
\hline 12 & $3096.26(121.9)$ & $107.442(4.23)$ & $1066.8(42)$ & 1.214 & 16.45 \\
\hline 13 & $3098.8(122.0)$ & $110.49(4.35)$ & $1778(70)$ & 2.005 & 45.47 \\
\hline 14 & $3098.8(122.0)$ & $110.49(4.35)$ & $1422.4(56)$ & 1.668 & 30.34 \\
\hline 15 & $3101.34(122.1)$ & $113.538(4.47)$ & $2133.6(84)$ & 1.668 & 45.66 \\
\hline 16 & $3101.34(122.1)$ & $.113 .538(4.47)$ & $2133.6(84)$ & 2.005 & 54.66 \\
\hline 21 & $3096.26(121.9)$ & $107.442(4.23)$ & $1066.8(42)$ & 1.654 & 18.96 \\
\hline 22 & $3096.26(121.9)$ & $107.442(4.23)$ & $1066.8(42)$ & 1.654 & 18.96 \\
\hline 23 & $3098.8(122.0)$ & $110.49(4.35)$ & $1778(70)$ & 2.739 & 52.56 \\
\hline 24 & $3098.8(122.0)$ & $110.49(4.35)$ & $1422.4(56)$ & 2.009 & 30.74 \\
\hline 25 & $3101.34(122.1)$ & $113.538(4.47)$ & $2133.6(84)$ & 2.739 & 63.06 \\
\hline$\frac{25}{26}$ & $3101.34(122.1)$ & $113.538(4.47)$ & $2133.6(84)$ & 2.009 & 46.40 \\
\hline 27 & $3106.42(122.3)$ & $116.84(4.60)$ & $2133.6(84)$ & 2.739 & 63.06 \\
\hline
\end{tabular}

${ }^{a}$ Historical documents give conflicting values. The largest reported as-built values are listed here. The conflicting values are less than $0.4 \%$ less.

1. Ref. 2 , Table 5

Table 3-16. Dimensions of Blanket Fuel Rods Parts [Ref. 9, Fig. II-5]

\begin{tabular}{|l|c|c|}
\hline \multicolumn{1}{|c|}{ Dimension [mm (in)] } & Bottom Mounted Rods & Top Mounted Rods \\
\hline Length of Plenum $^{2}$ & $251.46 \pm 1.397(9.9 \pm .055)$ & $251.46 \pm 1.397(9.9 \pm .055)$ \\
\hline Diameter of Mounting Stem & $<8.763(0.345)$ & $<8.763(0.345)$ \\
\hline Length of fixed-end plug & $67.31(2.65)$ & $33.02(1.30)$ \\
\hline Length of free-end plug & $34.29(1.350)$ & $41.91^{\circ}(1.650)$ \\
\hline Length of pellet stack & $2633.726(103.69)$ & $2660.396(104.74)$ \\
\hline
\end{tabular}

Includes hemispherical end.

1. Ref.2, Fig. 4

2. Ref. 14, p. 25

\subsection{Fuel Assemblies from the Blanket Regions}

There were 12 blanket modules, one surrounding each seed module. Blanket modules were categorized as Types I, II or III, depending on their shapes as viewed from above (Figure 3-2). Type I Blanket assemblies contain only Standard Blanket rods (Fig. 3-4), while Types II and III contain separate regions of Standard and Power Flattening Blanket Rods (Figure 3-5 and Figure 3-6). Key dimensions of the horizontal cross sections are given in Figure 3-10 and Table 3-17. Stabilization clamps on partially derodded assemblies alter the dimensions to some extent. [Ref. 12, Figs. A5-1, A5-2, and A5-3]

The as-built fissile concentration varied radially and axially within each assembly. The movable seed assemblies fit into $4.826-\mathrm{mm}(0.190$-in) thick Zircaloy-4 guide tubes that constituted the inner surfaces of the blanket assemblies. The interior distance between parallel interior faces of the blanket guide tubes was 258.572-mm (10.18-in). The blanket assemblies had 8 grids, the average masses of which are given in Table 3-18. The numbers of fuel rods per blanket assembly are given in Table 3-19. [Ref. 2, Fig. A1-2] 
Table 3-17. Dimensions of Blanket Modules.

(see Figure 3-11)

\begin{tabular}{|l|r|r|}
\hline \multirow{2}{*}{ Description (Refer to Figure 3-10) } & \multicolumn{2}{|c|}{ Value } \\
\cline { 2 - 3 } & \multicolumn{1}{|c|}{ Millimeters } & \multicolumn{1}{|c|}{ Inches } \\
\hline Type I & & \\
\hline Maximum corner-to-corner dimension & 501.396 & 19.74 \\
\hline Distance between interior faces of guide tube & 258.572 & 10.18 \\
\hline Thickness of the guide tube & 4.826 & 0.190 \\
\hline Type II & & \\
\hline Maximum corner-to-corner dimension & 561.848 & 22.12 \\
\hline Smaller exterior distance between parallel faces & 434.4416 & 17.104 \\
\hline Larger exterior distance between parallel faces & 489.996 & 19.29 \\
\hline Distance between interior faces of guide tube & 258.572 & 10.18 \\
\hline Thickness of the guide tube & 4.826 & 0.190 \\
\hline Type III & & \\
\hline Maximum corner-to-corner dimension & 561.848 & 22.12 \\
\hline Exterior distance between parallel faces & 489.996 & 19.29 \\
\hline Distance between interior faces of guide tube & 258.572 & 10.18 \\
\hline Thickness of the guide tube & 4.826 & 0.190 \\
\hline
\end{tabular}

Table 3-18. Average Masses of Grid Structures in the Blanket Regions [Ref. 14, Table 3-3]

\begin{tabular}{|c|c|c|c|c|}
\hline \multirow{2}{*}{$\begin{array}{c}\text { Assembly } \\
\text { Type }\end{array}$} & \multicolumn{4}{|c|}{ Masses of Grids (g/grid) } \\
\cline { 2 - 5 } & Standard Blanket & \multicolumn{2}{c|}{ Power-Flattening Blanket } \\
\hline Core Average & $\begin{array}{c}\text { Maximum } \\
\text { Assembly } \\
\text { Average }\end{array}$ & $\begin{array}{c}\text { Maximum } \\
\text { Assembly } \\
\text { Average }\end{array}$ \\
\hline II & 2232 & 2239 & Not Applicable & Not Applicable \\
\hline III & 1312 & 1314 & 1524 & 1525 \\
\hline
\end{tabular}


Table 3-19. Maximum Numbers of Rods of Each Type in Blanket and Reflector Modules. [Ref. 2, Figs. A1-2, Al-3, A1-4; Ref. 16, Fig, V-10 \& V-13]

\begin{tabular}{|c|c|c|c|c|c|}
\hline \multirow{2}{*}{$\begin{array}{l}\text { Rod } \\
\text { Type }\end{array}$} & \multicolumn{5}{|c|}{ Assembly Type ${ }^{a}$} \\
\hline & T & II & III & IV & $\mathbf{V}$ \\
\hline 11 & 60 & 39 & 29 & 0 & $\overline{0}$ \\
\hline 12 & 66 & 41 & 30 & 0 & 0 \\
\hline 13 & 78 & 45 & 32 & $\overline{0}$ & 0 \\
\hline 14 & 72 & 43 & 31 & 0 & 0 \\
\hline 15 & 84 & 46 & 32 & 0 & 0 \\
\hline 16 & 84 & 47 & 33 & 0 & 0 \\
\hline 21 & 0 & 21 & 31 & 0 & 0 \\
\hline 22 & 0 & 25 & 36 & $\overline{0}$ & $\overline{0}$ \\
\hline 23 & 0 & 33 & 46 & 0 & 0 \\
\hline 24 & 0 & 29 & 41 & $\overline{0}$ & 0 \\
\hline 25 & 0 & 179 & 276 & $\overline{0}$ & $\overline{0}$ \\
\hline 26 & 0 & 8 & 8 & $\overline{0}$ & 0 \\
\hline 27 & $\overline{0}$ & 8 & 8 & 0 & 0 \\
\hline 31 & 0 & $\overline{0}$ & 0 & 115 & 82 \\
\hline 32 & 0 & 0 & 0 & 113 & 84 \\
\hline Any & 444 & 564 & 633 & 228 & 166 \\
\hline
\end{tabular}




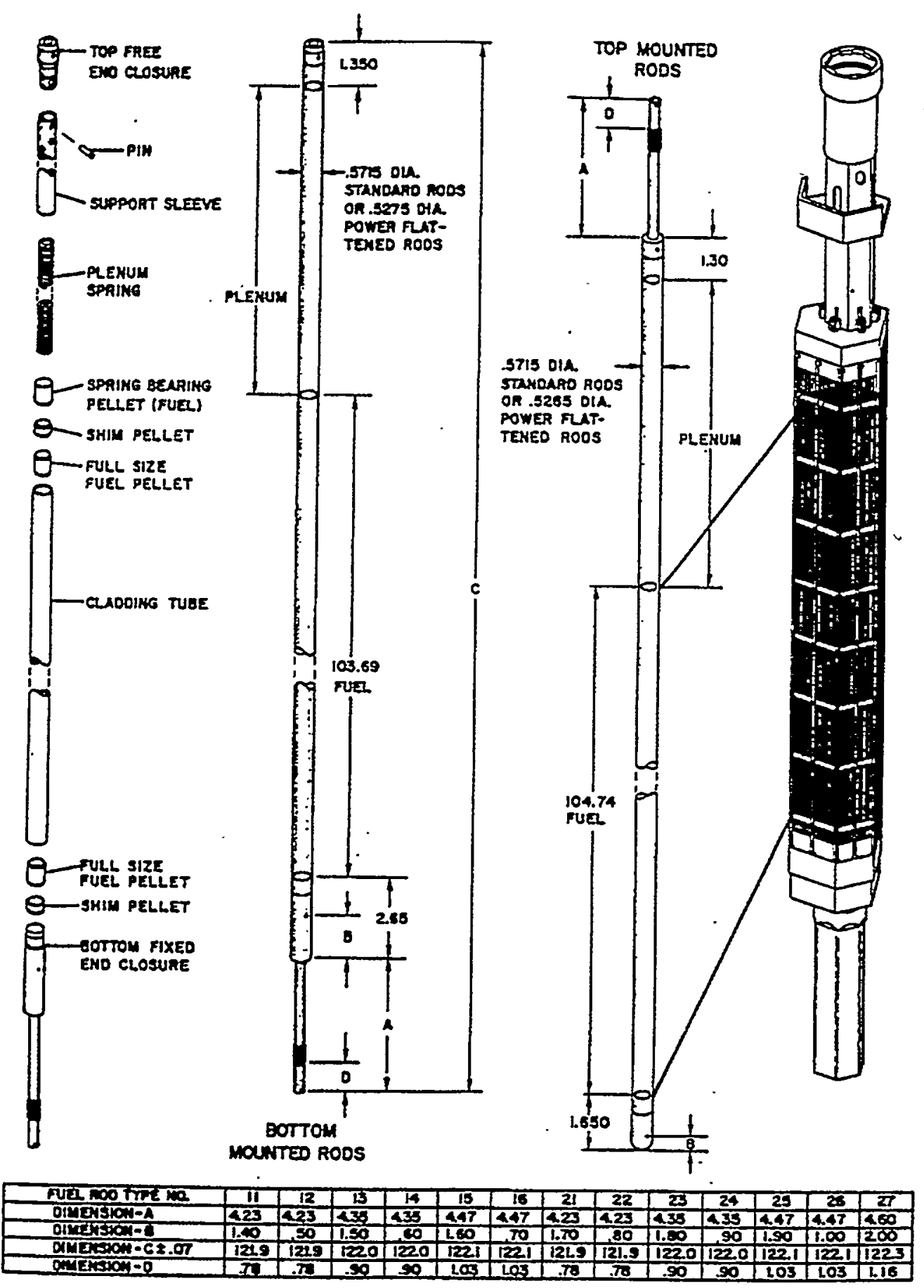

Figure 3-12. SCHEMATIC REPRESENTATION OF FUEL RODS FROM THE BLANKET REgIONS [Ref. 14, p. 30] 


\subsubsection{Description of SNF from the Reflector Region}

The Reflector Region was initially free of fissile material. There were two types of reflector modules (Type IV and V) based on their shapes (Figure 3-2).

\subsection{Fuel Pellets from the Reflector Region}

All pellets in reflector rods were thoria (no binary pellets). Pellets were right circular cylinders with square edges and they had dished ends to reduce axial expansion of the fuel stack. Reflector pellets were larger than pellets elsewhere in the core, with average as-built length $18.8214-\mathrm{mm}(0.741$-in) and diameter $18.83918-\mathrm{mm}(0.7417-\mathrm{in})$. The design specified a spherical radius of curvature of the end dishes of 80.0608-mm (3.152-in) and an end-dish depth of $0.3556 \pm 0.1016-\mathrm{mm}(0.014 \pm 0.004-\mathrm{in})$. The theoretical density of thoria is $9.999 \mathrm{~g} / \mathrm{cm}^{3}$. The sintering process achieved an as-built density of 97.282 percent of theoretical density. The fraction of the volume of the otherwise right cylindrical pellets that is missing because of tapers, dished ends, and chip defects, that is, the as-built void fraction, is 0.01317 . [Ref 14, p. 42]

\subsection{Fuel Rods from the Reflector Region}

Reflector rods were of two types: 31 and 32 (Figure 3-13). Both types initially contained only thoria pellets. Each reflector rod had a plenum at the top of the fuel stack, which housed an Inconel X-750 wire compression spring (Table 3-9) and a support sleeve of seamless Type 348 stainless steel tubing. The spring discouraged the formation of gaps between pellets while the support sleeve prevented collapse of the cladding against the compression spring. The length of the pellet stack was different for top- and bottom-mounted rods (Table 3-20) Top-mounted rods had hemispherical free-end plugs of Zircaloy-4 (Table 3-20). Bottom-mounted rods had square free-end plugs of Zircaloy-4 (Table 3-20). The diameter of the mounting stems is not precisely known, but historical documents imply that it does not exceed the value given in Table 3-20 [Ref.13, Fig. 5 and Ref. 9, note 1 of Figures II-4, II-5, and II6]. Inner and outer diameters of the Zircaloy-4 cladding are given in Table 3-8.

Table 3-20. Dimensions of Reflector Fuel Rods [Overall length, length of mounting stem, and lengths of end plugs are from Ref. 9].

\begin{tabular}{|l|c|c|}
\hline \multicolumn{1}{|c|}{ Dimension [mm (in)] } & Bottom Mounted Rods (Type 31) & Top Mounted Rods (Type 32) \\
\hline Overall Length & $2813.558(110.77)$ & $2813.558(110.77)$ \\
\hline Length of Fuel Stack & $2563.876(100.94)$ & $2614.676(102.94)$ \\
\hline Length of Plenum & $100.457 \pm 1.016(3.955 \pm 0.040)$ & $100.457 \pm 1.016(3.955 \pm 0.040)$ \\
\hline Length of Mounting Stem & $75.692(2.98)$ & $75.692(2.98)$ \\
\hline Diameter of Mounting Stem & $<8.763(0.345)$ & $<8.763(0.345)$ \\
\hline Length of fixed-end plug & $95.25(3.75)$ & $53.975(2.125)$ \\
\hline Length of free-end plug & $53.975(2.125)$ & $44.45^{\circ}(1.75)$ \\
\hline
\end{tabular}




\subsection{Fuel Assemblies from the Reflector Region}

There were 15 reflector assemblies. Reflector assemblies are categorized into Types IV and V, depending on their shapes as viewed from above (Figures 3-2, 3-14 and 3-15). The numbering of assemblies by Arabic numerals within each type gives each assembly a unique identifier. Key dimensions of the horizontal cross sections are given in Figure 3-11 and Table 3-21. Stabilization clamps on partially derodded assemblies alter the dimensions to some extent. The numbers of rods of each type in reflector assemblies are given in Table 3-18. Assemblies in the reflector region had six grids composed of AM-350 stainless steel. The volume of the grid metal in the fuel lattice was 6.915 $\mathrm{cm}^{3}\left(0.422 \mathrm{in}^{3}\right)$ per fuel rod, which accounts for 80 percent of the total grid volume in the reflector assemblies. [Ref. 6, Table II-1]

Table 3-21. Dimensions of Reflector Assemblies

[Ref. 12, Fig. 24]

\begin{tabular}{|c|r|r|}
\hline \multirow{2}{*}{ Description } & \multicolumn{2}{|c|}{ Value } \\
\cline { 2 - 3 } & Millimeters & \multicolumn{1}{|c|}{ Inches } \\
\hline Type IV Assembly (metaphorically considered as a house) & & \\
\hline "Foundation" width & 434.4416 & 17.104 \\
\hline "Rooftop" to "foundation" dimension & 350.3676 & 13.794 \\
\hline Maximum corner-to-corner dimension & 489.204 & 19.26 \\
\hline "Foundation" thickness & 16.51 & 0.65 \\
\hline "Wall" thickness & 5.334 & 0.21 \\
\hline "Roof" thickness & 6.35 & 0.25 \\
\hline Type V Assembly (considered as a trapezoid on its base) & & \\
\hline "Base" width (maximum corner-to-corner dimension) & 539.877 & 21.255 \\
\hline "Height" & 229.235 & 9.025 \\
\hline "Top" width & 314.9346 & 12.399 \\
\hline "Base" thickness & 16.51 & 0.65 \\
\hline "Sides" thickness & 14.224 & 0.56 \\
\hline "Top" thickness & 4.62 & 0.30 \\
\hline
\end{tabular}




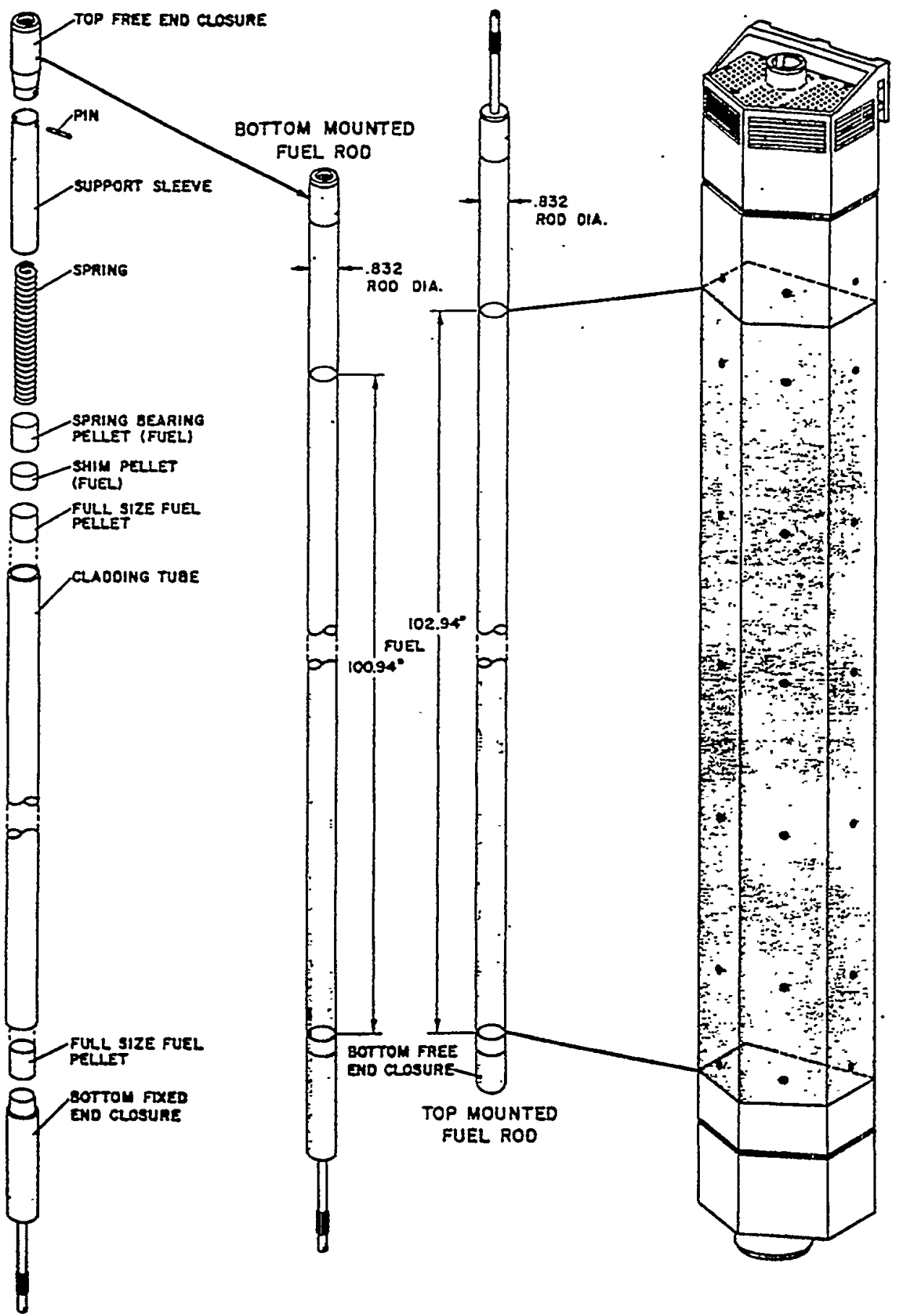

FigURE 3-13. SCHEMATIC REPRESENTATION OF REFLECTOR FUEL RODS [Ref. 2, Fig. 5] 


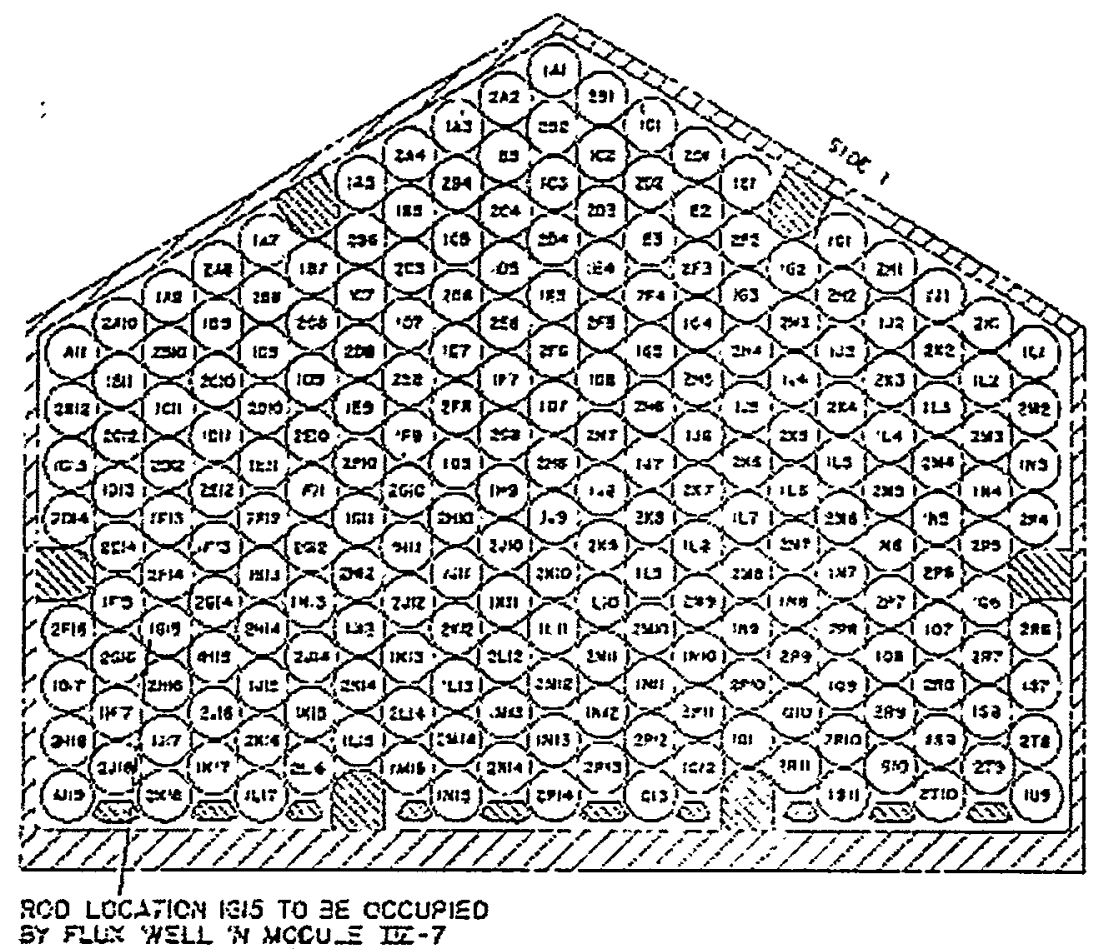

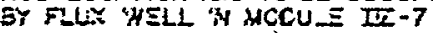

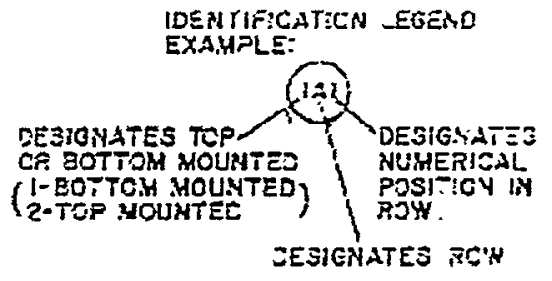

a2s RODS (II FCP HCUNTED)

832 Did.

sae pitcit

Figure 3-14. LAYOUT OF RODS IN A TYPE IV REFLECTOR ASSEMBLY

[Ref. 14, p. 17] 

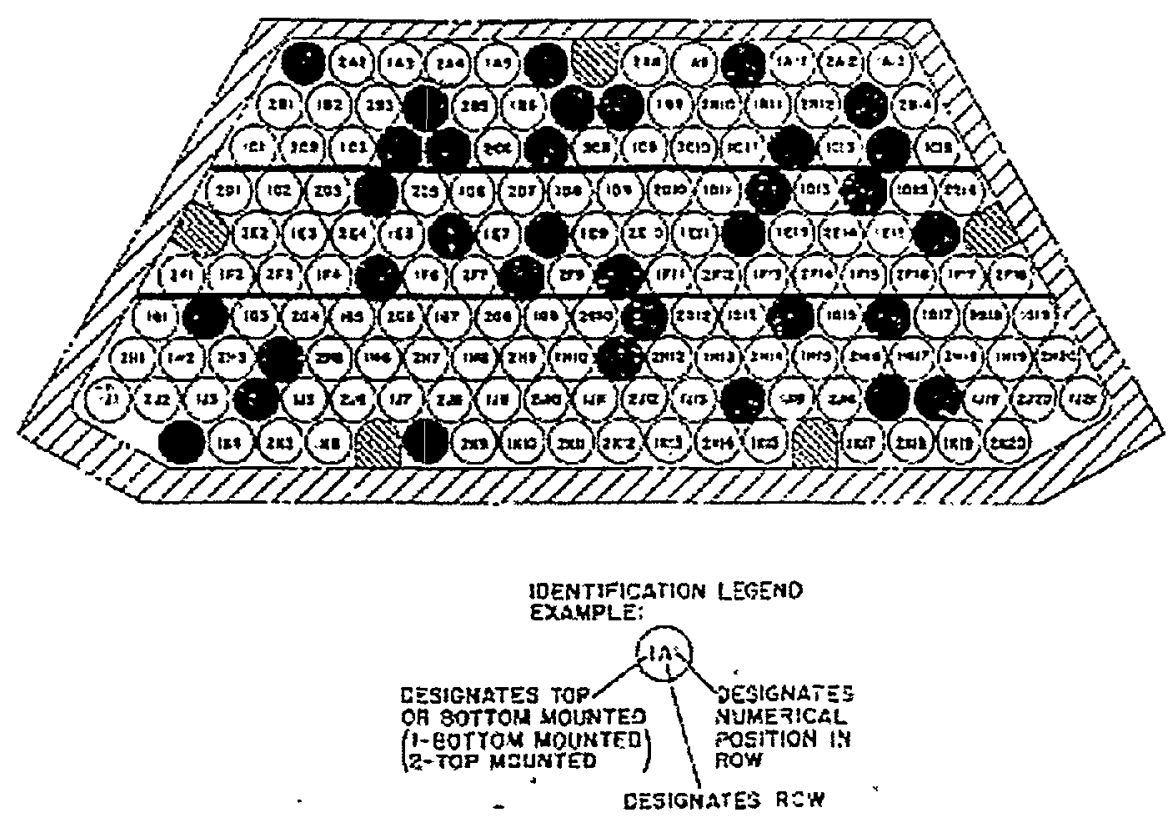

Figure 3-15. LAyOUT OF RodS IN A TYPE V REFLECTOR ASSEMBLy

[Ref. 14, p. 18]

\subsubsection{Thermal}

Decay heat for intact assemblies can be estimated from predicted decay heat curves that were developed for the Shippingport LWBR. The decay heat curves represent the decay heat generation rates as a function of cooling time for the hottest intact seed, blanket, and reflector assemblies. As documented in Olson, et al. (1999), the maximum estimated heat generation rates for the various assemblies in 1992 (ten years after shutdown) are: [Ref. 14, p. 131]

Seed Assemblies (assuming 619 rods):

Blanket Assemblies (assuming 564 rods):

Reflector Assemblies (assuming 228 rods):
$630 \mathrm{~W}(2,150 \mathrm{BTU} / \mathrm{hr})$

$527 \mathrm{~W}(1,800 \mathrm{BTU} / \mathrm{hr})$

$175 \mathrm{~W}(600 \mathrm{BTU} / \mathrm{hr})$.

Further information on decay-heat from LWBR fuel comes from simulations performed with ORIGEN2, a computer program from the Radiation Safety Information Computational Center, which is associated with Oak Ridge National Laboratory. ORIGEN2 has been used to simulate the burn-up and decay of Shippingport LWBR Seed assembly. [Ref. 19] The thermal power due to radioactive decay (Table B-7) can be derived from the isotopic activities (Table B-6). The simulated extent of burn-up was 10,269.14 MWd per seed assembly. The assumed initial fissile loading of the simulated seed assembly was $16,892.84 \mathrm{~g}$, which is approximately $2 \%$ greater than the average initial fissile loading reported in Table 3-11. These ORIGEN calculations indicate a slight decrease in heat generation per seed assembly (extrapolated to $\sim 500 \mathrm{~W} /$ assembly in 1992 from Figure B-1 vs. $630 \mathrm{~W}$ reported above).

Estimates of axial thermal peaking factors can be derived from average and peak burnup data for individual fuel rods (Table 3-22). Estimates of the thermal conductivity of the two components $\left(\mathrm{UO}_{2}\right.$ 
and $\mathrm{ThO}_{2}$ ) of the unirradiated fuel at elevated temperatures as a function of temperature [Ref. 5, Table 7] are presented in Table 3-23.

Table 3-22. Axial Peaking Factors Estimated from Peak and Average Burnups [Ref. 5, p. 13]

\begin{tabular}{|l|r|r|c|}
\hline \multicolumn{1}{|c|}{ Core Region } & $\begin{array}{c}\text { Peak Burnup } \\
\text { (MWd/MTHM) }\end{array}$ & $\begin{array}{c}\text { Maximum Rod } \\
\text { Average Burnup } \\
\text { (MWd/MTHM) }\end{array}$ & $\begin{array}{c}\text { Estimated } \\
\text { Axial Peaking } \\
\text { Factor }\end{array}$ \\
\hline Seed & 53,400 & 29,800 & 1.79 \\
\hline Standard Blanket & 23,200 & 13,200 & 1.76 \\
\hline Power Flattening Blanket & 25,200 & 14,700 & 1.71 \\
\hline Reflector & 4,500 & 2,200 & 2.05 \\
\hline
\end{tabular}

Table 3-23. Thermal Conductivity of $\mathrm{UO}_{2}$ and Thoria Fuel [Ref. 5, p. 30]

\begin{tabular}{|c|c|c|}
\hline \multirow{2}{*}{$\begin{array}{c}\text { Temperature } \\
\left.\text { ( }{ }^{\circ} \mathrm{F}\right)\end{array}$} & $\begin{array}{c}\text { Thermal Conductivity } \\
\left(\mathrm{Btu} / \mathrm{hr} / \mathrm{ft}^{\circ}{ }^{\circ} \mathrm{F}\right)\end{array}$ \\
\cline { 2 - 3 } & $\mathrm{UO}_{2}$ & $\mathrm{ThO}_{2}$ \\
\hline 500 & 3.4 & 4.1 \\
\hline 1000 & 2.7 & 3.2 \\
\hline 2000 & 1.8 & 2.1 \\
\hline 3000 & 1.4 & 1.6 \\
\hline 4000 & 1.1 & 1.2 \\
\hline
\end{tabular}

\subsubsection{Burn-up Data}

Peak burnups (estimated and design) are shown in Table 3-24 for the various module types.

Table 3-24. Peak burnups (MWD/MTM)

[from Ref. 5, Table 1].

\begin{tabular}{|l|l|l|l|l|}
\hline Burnup & Seed & $\begin{array}{l}\text { Standard } \\
\text { Blanket }\end{array}$ & $\begin{array}{l}\text { Power Flattening } \\
\text { Blanket }\end{array}$ & Reflector \\
\hline $\begin{array}{l}\text { Best Estimate at } 18,000 \\
\text { EFPH }\end{array}$ & 38,900 & 15,200 & 17,000 & 2,400 \\
\hline $\begin{array}{l}\text { Best Estimate at 29,047 } \\
\text { EFPH }\end{array}$ & 53,400 & 23,200 & 25,200 & 4,500 \\
\hline Design at 18,000 EFPH & 45,300 & 19,000 & 20,500 & 2,800 \\
\hline Design at 29,047 EFPH & 62,500 & 29,600 & 30,800 & 5,600 \\
\hline
\end{tabular}


Table 3-25. Fuel Quantities Assumed for the ORIGEN2 Calculations

\begin{tabular}{|c|c|c|c|c|}
\hline Assembly Type & $\begin{array}{l}\text { Basis of } \\
\text { Comparison }\end{array}$ & $\begin{array}{l}\text { Best Estimate } \\
\text { (Table 3-11) }\end{array}$ & $\begin{array}{l}\text { Assumed for the } \\
\text { ORIGEN2 } \\
\text { Calculation }\end{array}$ & $\begin{array}{l}\text { Percent } \\
\text { Difference }\end{array}$ \\
\hline Seed I & Fissile Loading & 16.53 & 16.89 & 2.2 \\
\hline Blanket II & Fissile Loading & 25.00 & 25.02 & 0.1 \\
\hline Blanket III & Fissile Loading & 29.85 & 29.44 & -1.4 \\
\hline Reflector IV & Thoria Fuel Mass & $1580^{a}$ & $1637^{b}$ & 3.6 \\
\hline \multicolumn{5}{|c|}{$\begin{array}{l}\text { a Calculated as the fuel mass (from Table } 3-10 \text { ) times the number of rods } \\
\text { (from Table } 3-19 \text { ) } \\
b \text { Calculated as the thorium mass plus the thorium mass times twice the ratio of the } \\
\text { atomic weight of oxygen to that of thorium }\end{array}$} \\
\hline
\end{tabular}

\subsubsection{Chemical Properties}

The LWBR core was fueled with fertile Th-232 and fissile U-233, the relative concentrations of which varied axially and radially across the core to promote high neutron economy. The uranium that was used in fabricating the fuel was very highly enriched in U-233, but some isotopic impurities were present (Table 3-1). The design called for vertical fuel rods on a triangular pitch with the space between taken up by circulating cooling water. The fuel rods featured cladding tubes loaded with cylindrical fuel pellets of thoria $\left(\mathrm{ThO}_{2}\right)$ or a binary mixture of thoria and $\mathrm{UO}_{2}$ and backfilled with helium at one atmosphere during welding [Ref. 14, and Ref. 5, p. 70.] The binary fuel is a solid solution fabricated from the two oxides in powder form. Processing of the well-mixed powder preparation achieved a nearly homogeneous structure owing to diffusion at elevated temperature during sintering [Ref. 18, Section II.C.3, p. II-3.]. Axial variation in fissile material concentration was achieved by loading individual fuel rods such that part of the length bore a binary mixture of fissile and fertile material and the rest bore only fertile material. Radial variation was achieved by the arrangement of fuel rods that differed in their axial loading and by using binary pellets of different binary mixtures, depending on the radial location of the rod. Zircaloy- 4 with hafnium content less than $40 \mathrm{ppm}$ was used for the cladding tubes and all other structures in the fuel region, except the grids, which were made of AM-350 stainless steel. The fuel and fuel components suffered minimal damage during operation. Extensive destructive and non-destructive examinations after shutdown confirmed that the fuel was in good condition with minimal deformation of the cladding and minimal cracking of fuel pellets. 


\section{DOE SNF Canister}

A standard canister design has been proposed for use in the packaging, transport, and disposal of DOE SNF fuels [Ref. 17]. The canister design (Figure 4.1) includes nominal lengths of either 10- or 15-feet and diameters of 18- or 24-in. Beyond these basic dimensions, fuel-specific internals will be designed for each canister that provides fuel separation and/or a method of fixing neutron poisons within the package.

Current storage of all LWBR fuels precludes use of either standard canister diameter without some type of repackaging. In the case of LWBR fuel assemblies other than the seed assemblies, dimensional constraints may dictate some form of disassembly to utilize even the 24-in. canister.

\subsection{DOE SNF Canister}

The following conceptual design for the DOE SNF canister is taken from Reference 17, pages 4-6, and Appendix A. The canister is a right circular cylinder of stainless steel (Type 316L). This canister must be able to stand vertically when placed on a flat surface after being loaded with the SNF. The dimensions for the DOE SNF canister are a 457.2-mm (18.00-in.) outer diameter with a 9.525-mm $(0.375$-in.) wall thickness. The nominal internal length of the canister is $4117-\mathrm{mm}(162.09$-in.) and the nominal overall length is $4569-\mathrm{mm}$ (179.92-in.). The canister maximum total weight is $2,721 \mathrm{~kg}$. There is a tapered bottom carbon steel impact plate that varies in thickness from 15.24-mm (0.60-in.) at the edge to $50.8-\mathrm{mm}(2.0-\mathrm{in}$.) in the center at the top and bottom boundaries of the canister. Length dimension of seed assemblies dictates use of the 15 - $\mathrm{ft}$ long SNF canisters. 


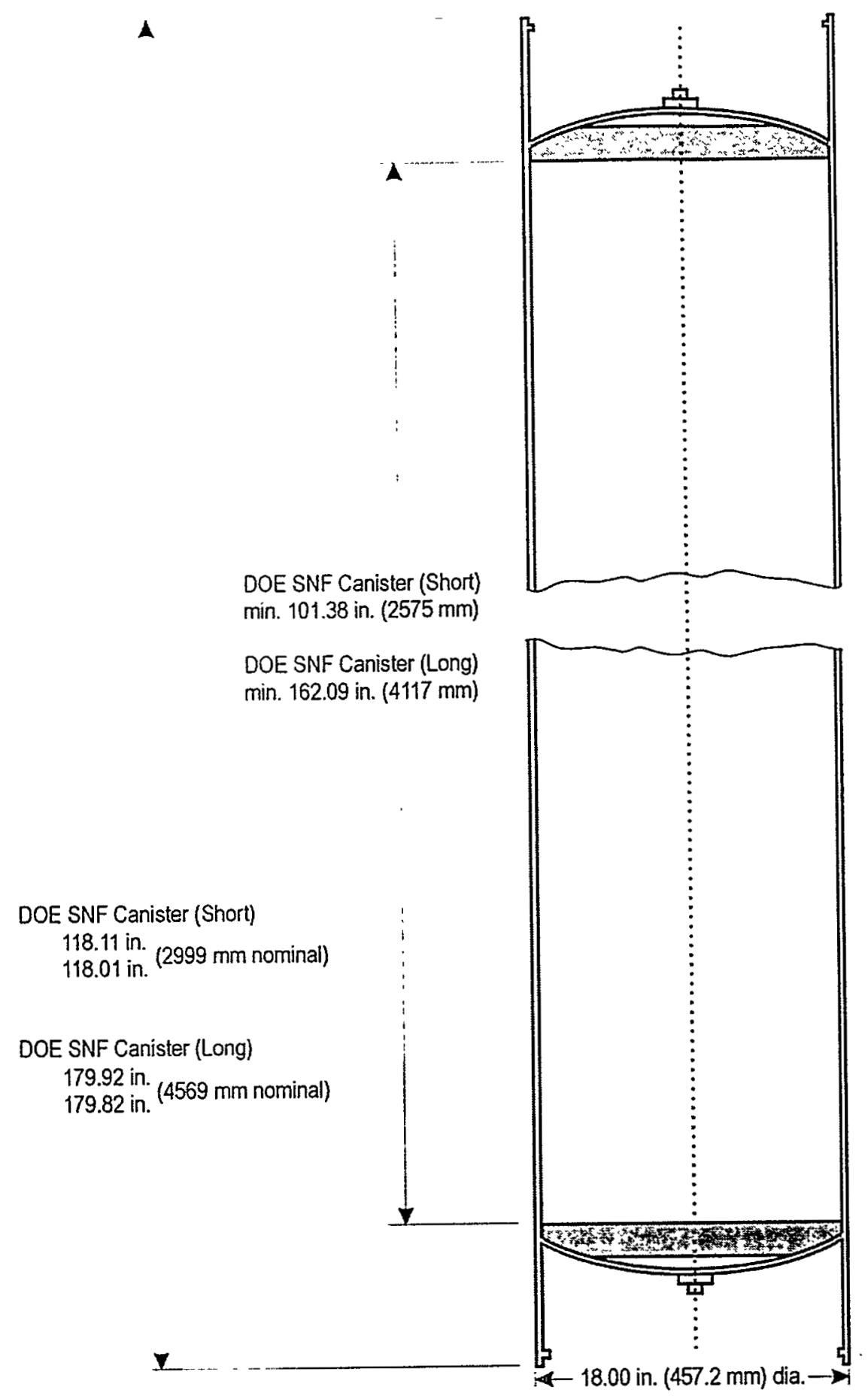

Figure 4-1. 18-in. SNF Canister Section VieW

[Ref. 17] 


\section{References}

1. Benedict, M., Pigford, T.H., and Levi, H. W., 1981, Nuclear Chemical Engineering, $2^{\text {nd }}$ Edition., McGraw-Hill Book Co, New York, N.Y.

2. Bettis, 1987, End-of-Life Nondestructive Examination of Light Water Breeder Reactor Fuel Rods, Gorscak D. A., WAPD-TM-1605

3. Bettis, 1983, The Installation of the LWBR at the Shippingport Atomic Power Station (LWBR Development Program), Massimo R. J., WAPD-TM-1342

4. Bettis, 1987, Water Cooled Breeder Program Summary Report (LWBR Development Program), WAPD-TM-1600

5. Bettis, 1987, Light Water Breeder Reactor Fuel Rod Design and Performance Characteristics (LWBR Development Program), Campbell W. R., WAPD-TM-1387

6. Bettis, 1979, Summary of the Nuclear Design and Performance of the Light Water Breeder Reactor (LWBR), Hecker H. C., WAPD-TM-1326

7. Bettis, 1981, Results of Initial Nuclear Tests on LWBR (LWBR Development Program), Sarber W. K., WAPD-TM-1336

8. Bettis, 1979, Design Features of the Light Water Breeder Reactor (LWBR) Which Improve Fuel Utilization in Light Water Reactors (LWBR Development Program), Hecker H. C., WAPD-TM1409

9. Bettis, 1986, The Fabrication and Loading of Fuel Rods and the Light Water Breeder Reactor (LWBR Development Program), Degeorge V. V., WAPD-TM-1278

10. Bettis, 1987, End-of-Life Destructive Examination of Light Water Breeder Reactor Fuel Rods, Richardson K.D., WAPD-TM-1606

11. Bettis, 1987, Preparation of LWBR Spent Fuel for Shipment to ICPP for Long Term Storage,WAPD-TM-1601

12. Bettis, 1987, Primary Disassembly of Light Water Breeder Reactor Modules for Core Evaluation (LWBR Development Program), Greenberger R. J., WAPD-TM-1608

13. Bettis, 1987, Light Water Breeder Reactor Core Evaluation Operations at the Expended Core Facility (LWBR Development Program), Williams J. T.,WAPD-TM-1611

14. INEEL, 1999, Fuel Summary Report: Shippingport Light Water Breeder Reactor, Olson G. L. et al, INEEL/EXT-98-00799, Idaho Falls, ID 
15. Bettis, 1987, Light Water Breeder Reactor Fuel Module Disassembly at the Shippingport Atomic Power Station (LWBR Development Program), Selsley I. A., WAPD-TM-1552

16. Bettis, 1987, Proof of Breeding in the Light Water Breeder Reactor, Schick Jr. J. R.,WAPD-TM1612

17. INEEL 1998, Preliminary Design Specification for Department of Energy Standardized Spent Nuclear Fuel Canisters, Volume I - Design Specification. DOE/SNF/REP-011, Rev. 3. Idaho Falls, ID, Lockheed Martin Idaho Technologies

18. Bettis, 1976, $\mathrm{ThO}_{2}$ and $\mathrm{ThO}_{2-}{ }^{233} \mathrm{UO}_{2}$ High Density Fuel Pellet Manufacture for the Light Water Breeder Reactor (LWBR Development Program), Belle J., WAPD-TM-1244(L)

19. INEEL, LIMITCO company internal, ORIGEN calculation for LWBR seed assembly, J. W. Sterbentz

20. INEL 1997, Appendix Y - Isotopic Conversion Factors, Radionuclide Mass Inventory, Activity, Decay Heat, and Dose-Rate Parametric Data for TRIGA Spent Nuclear Fuels, INEL-96/0482, Idaho Falls, ID 
总 


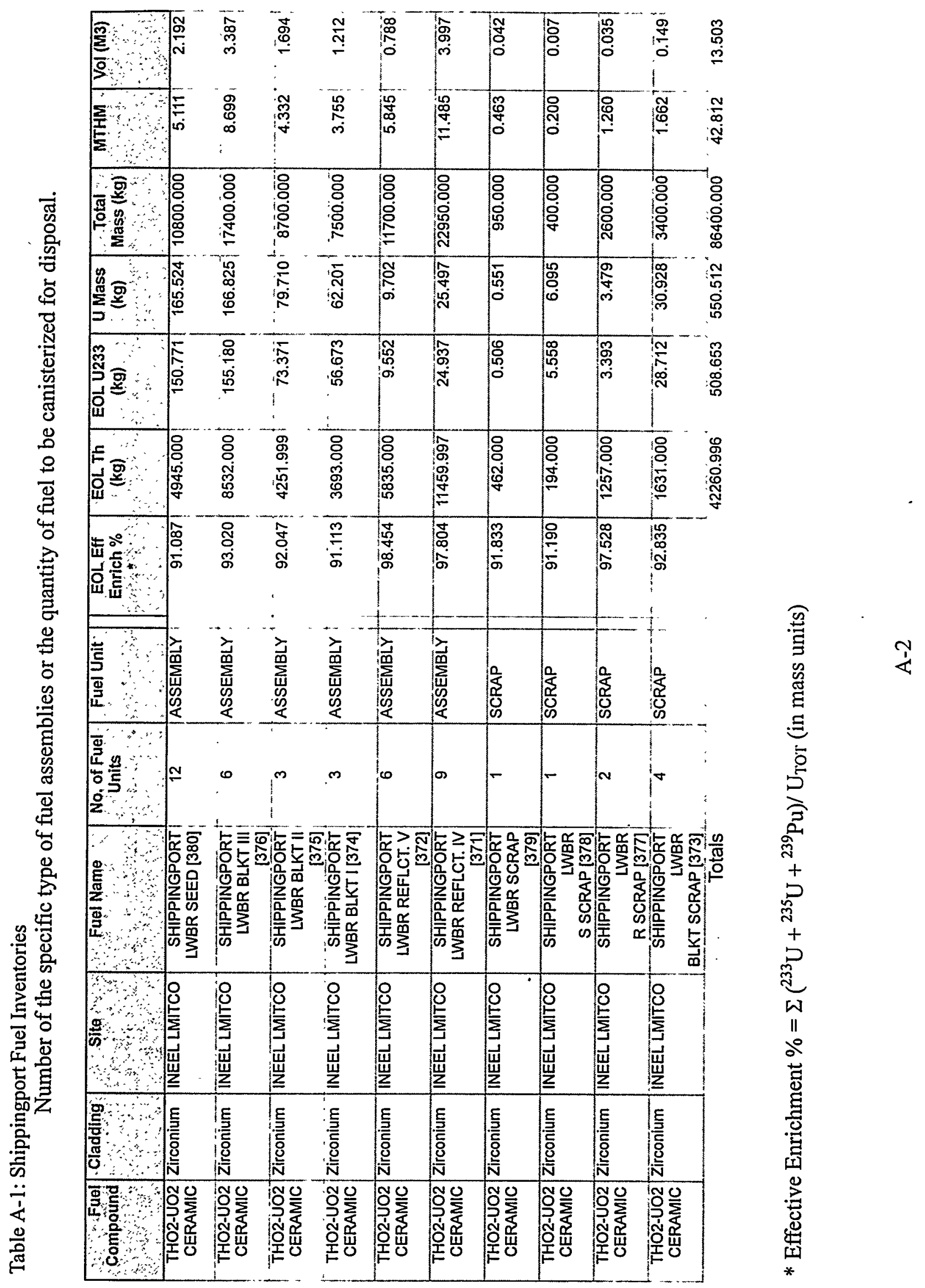




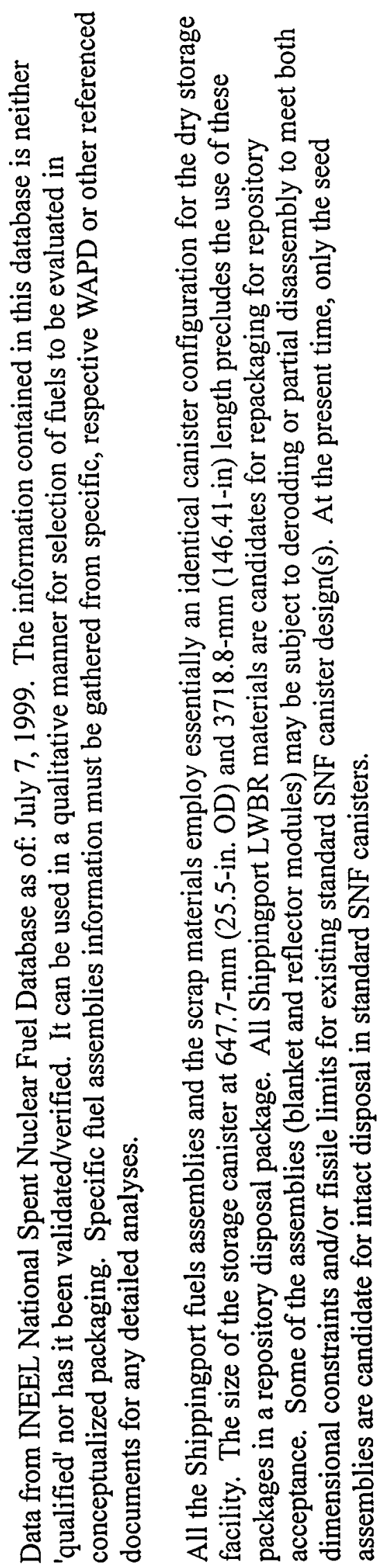


APPENDIX B: Burnup Data

B-1 


\section{Time Since Last Irradiation}

Operation of the Shippingport LWBR reactor configuration covered five years between 1977 and 1982 ,

\section{Shielding Source Terms}

The gamma sources for the Shippingport seed fuel assemblies are given below in Table B-1 through B-3. These values represent the highest source exhibited by any LWBR assembly; refer to Section 3.1.2 for comparative heat generation rates for other types of assemblies. Photon values are for the years listed.

Table B-1 Photon Spectra for Activation Products [Ref. 19]

\begin{tabular}{|c|c|c|c|c|c|c|c|}
\hline \multirow{2}{*}{$\begin{array}{c}\text { Mean } \\
\text { Photon } \\
\text { Energy } \\
\text { (MeV) }\end{array}$} & \multicolumn{7}{|c|}{$\begin{array}{l}\text { Calculated Photon Spectrum }{ }^{a} \text { as of Year } \\
\text { (Photons/sec) }\end{array}$} \\
\hline & 2000 & 2005 & 2010 & 2015 & 2020 & 2025 & 2030 \\
\hline $1.50 \mathrm{E}-02$ & $2.363 E+11$ & $1.208 \mathrm{E}+11$ & $6.521 E+10$ & $3.692 \mathrm{E}+10$ & $2.196 \mathrm{E}+10$ & $1.383 \mathrm{E}+10$ & $9.297 \mathrm{E}+09$ \\
\hline $2.50 \mathrm{E}-02$ & $3.312 \mathrm{E}+11$ & $1.034 \mathrm{E}+11$ & $3.441 E+10$ & $1.262 E+10$ & $5.253 E+09$ & $2.519 \mathrm{E}+09$ & $1.380 E+09$ \\
\hline $3.75 \mathrm{E}-02$ & $1.482 \mathrm{E}+11$ & $6.585 \mathrm{E}+10$ & $3.369 E+10$ & $1.916 E+10$ & $1.165 \mathrm{E}+10$ & $7.374 \mathrm{E}+09$ & $4.779 E+09$ \\
\hline $5.75 \mathrm{E}-02$ & $3.548 \mathrm{E}+10$ & $1.967 \mathrm{E}+10$ & $1.129 \mathrm{E}+10$ & $6.668 \mathrm{E}+09$ & $4.031 E+09$ & $2.492 \mathrm{E}+09$ & $1.574 E+09$ \\
\hline $8.50 \mathrm{E}-02$ & $2.319 \mathrm{E}+10$ & $1.187 E+10$ & $E+09$ & $3.297 E+09$ & $E+09$ & $9.915 \mathrm{E}+08$ & $5.642 \mathrm{E}+08$ \\
\hline $1.25 \mathrm{E}-01$ & $8.814 E+10$ & $5.647 \mathrm{E}+10$ & $3.671 E+10$ & $2.407 E+10$ & $1.586 E+10$ & $1.050 \mathrm{E}+10$ & $E+09$ \\
\hline $2.25 \mathrm{E}-01$ & $4.352 \mathrm{E}+10$ & $1.869 \mathrm{E}+10$ & $9.490 E+09$ & $5.469 \mathrm{E}+09$ & $3.398 \mathrm{E}+09$ & $2.196 \mathrm{E}+09$ & $1.445 \mathrm{E}+09$ \\
\hline $3.75 \mathrm{E}-01$ & $1.623 \mathrm{E}+11$ & $4.747 E+10$ & $1.427 E+10$ & $4.534 \mathrm{E}+09$ & $1.597 E+09$ & $6.575 \mathrm{E}+08$ & $3.222 E+08$ \\
\hline $5.75 \mathrm{E}-01$ & $2.228 E+11$ & $7.054 \mathrm{E}+10$ & $2.472 E+10$ & $1.011 \mathrm{E}+10$ & $4.917 \mathrm{E}+09$ & $2.761 \mathrm{E}+09$ & $1.695 \mathrm{E}+09$ \\
\hline $8.50 \mathrm{E}-01$ & $9.099 \mathrm{E}+10$ & $6.130 \mathrm{E}+10$ & $4.148 \mathrm{E}+10$ & $2.823 E+10$ & $1.938 E+10$ & $1.347 \mathrm{E}+10$ & $9.519 \mathrm{E}+09$ \\
\hline $1.25 E+00$ & 6.15 & 3.20 & $=+12$ & $8.714 E+11$ & & $=+11$ & $E+11$ \\
\hline $1.75 E+00$ & $2.960 \mathrm{E}+09$ & $1.979 E+09$ & $1.322 E+09$ & $8.839 E+08$ & $5.906 \mathrm{E}+08$ & $3.948 \mathrm{E}+08$ & $2.638 E+08$ \\
\hline $2.25 E+00$ & $3.208 \mathrm{E}+07$ & $1.662 E+07$ & $8.612 \mathrm{E}+06$ & $4.462 E+06$ & $2.311 E+06$ & $1.197 \mathrm{E}+06$ & $6.204 \mathrm{E}+05$ \\
\hline $2.75 E+00$ & $9.928 \mathrm{E}+04$ & $5.144 E+04$ & $2.665 E+04$ & $1.381 \mathrm{E}+04$ & $E+03$ & $3.705 \mathrm{E}+03$ & $1.920 \mathrm{E}+03$ \\
\hline $3.50 E+00$ & $1.628 \mathrm{E}-06$ & $1.468 \mathrm{E}-06$ & $1.323 \mathrm{E}-06$ & $1.193 \mathrm{E}-06$ & 1.07 & $9.704 \mathrm{E}-07$ & $8.755 \mathrm{E}-07$ \\
\hline $5.00 E+00$ & $5.276 \mathrm{E}-09$ & $5.276 \mathrm{E}-09$ & $5.276 \mathrm{E}-09$ & $5.276 \mathrm{E}-09$ & $5.276 \mathrm{E}-09$ & $5.276 \mathrm{E}-09$ & $5.276 \mathrm{E}-09$ \\
\hline $7.00 \mathrm{E}+00$ & $3.423 \mathrm{E}-10$ & $3.423 \mathrm{E}-10$ & $3.423 \mathrm{E}-10$ & $3.423 \mathrm{E}-10$ & $3.423 \mathrm{E}-10$ & $3.423 \mathrm{E}-10$ & $3.423 \mathrm{E}-10$ \\
\hline $1.10 E+01$ & $2.165 \mathrm{E}-11$ & 2.1 & $E-11$ & $2.165 E-11$ & 2.1 & $2.165 \mathrm{E}-11$ & $2.165 E-11$ \\
\hline Sum & $7.537 \mathrm{E}+12$ & $3.781 \mathrm{E}+12$ & $1.948 \mathrm{E}+12$ & $1.023 E+12$ & $5.462 E+11$ & $2.963 \mathrm{E}+11$ & $1.637 E+11$ \\
\hline
\end{tabular}

The basis for the ORIGEN2 simulation is a Seed assembly. The initial fissile loading of the simulated assembly is $16,892.84 \mathrm{~g}$, which is approximately $2 \%$ greater than the actual initial fissile loading. The simulated burnup is $10,269.14 \mathrm{MWd}$ for the assembly. 
Table B-2 Calculated Photon Spectra from Actinides and Their Daughters in Seed Fuel [Ref. 19]

\begin{tabular}{|c|c|c|c|c|c|c|c|}
\hline \multirow{2}{*}{$\begin{array}{c}\text { Mean } \\
\text { Photon } \\
\text { Energy } \\
(\mathrm{MeV})\end{array}$} & \multicolumn{7}{|c|}{$\begin{array}{l}\text { Calculated Photon Spectrum }{ }^{\mathrm{a}} \text { as of Year } \\
\text { (Photon/s) }\end{array}$} \\
\hline & 2000 & 2005 & 2010 & 2015 & 2020 & 2025 & 2030 \\
\hline $1.50 \mathrm{E}-02$ & $1.618 \mathrm{E}+13$ & $1.546 \mathrm{E}+13$ & $1.476 \mathrm{E}+13$ & $1.410 \mathrm{E}+13$ & $1.347 E+13$ & $1.288 \mathrm{E}+13$ & $1.230 \mathrm{E}+13$ \\
\hline $2.50 \mathrm{E}-02$ & $1.273 E+12$ & $1.215 \mathrm{E}+12$ & $1.158 \mathrm{E}+12$ & $1.105 E+12$ & $1.054 \mathrm{E}+12$ & $1.006 E+12$ & $9.597 \mathrm{E}+11$ \\
\hline $3.75 \mathrm{E}-02$ & $1.027 E+12$ & $9.808 \mathrm{E}+11$ & $9.359 \mathrm{E}+11$ & $8.939 E+11$ & $8.538 E+11$ & $8.157 \mathrm{E}+11$ & $7.794 E+11$ \\
\hline $5.75 \mathrm{E}-02$ & $1.210 E+12$ & $1.159 \mathrm{E}+12$ & $1.108 \mathrm{E}+12$ & $1.061 \mathrm{E}+12$ & $1.015 E+12$ & $9.706 \mathrm{E}+11$ & $9.283 E+11$ \\
\hline $8.50 \mathrm{E}-02$ & $7.368 \mathrm{E}+12$ & $7.029 \mathrm{E}+12$ & $6.700 \mathrm{E}+12$ & $6.390 \mathrm{E}+12$ & $6.095 E+12$ & $5.814 E+12$ & $5.546 E+12$ \\
\hline $1.25 \mathrm{E}-01$ & $5.667 E+11$ & $5.412 \mathrm{E}+11$ & $3 E+11$ & $4.929 \mathrm{E}+11$ & $4.706 \mathrm{E}+11$ & $4.494 \mathrm{E}+11$ & $4.291 E+11$ \\
\hline $2.25 \mathrm{E}-01$ & $1.034 E+13$ & $9.856 \mathrm{E}+12$ & $9.390 \mathrm{E}+12$ & $8.953 E+12$ & $8.535 E+12$ & $8.138 \mathrm{E}+12$ & $7.759 \mathrm{E}+12$ \\
\hline 3.75E-01 & $7.490 \mathrm{E}+11$ & $7.169 \mathrm{E}+11$ & $6.855 \mathrm{E}+11$ & $6.560 \mathrm{E}+11$ & $6.279 \mathrm{E}+11$ & $6.010 \mathrm{E}+11$ & $3 \mathrm{E}+11$ \\
\hline $5.75 \mathrm{E}-01$ & $6.864 E+12$ & $6.543 \mathrm{E}+12$ & +12 & $5.938 \mathrm{E}+12$ & $5.659 \mathrm{E}+12$ & $5.394 \mathrm{E}+12$ & $5.140 \mathrm{E}+12$ \\
\hline $8.50 \mathrm{E}-01$ & $3.190 \mathrm{E}+12$ & $3.041 E+12$ & $2.896 \mathrm{E}+12$ & $2.761 \mathrm{E}+12$ & $2.631 \mathrm{E}+12$ & $2.508 \mathrm{E}+12$ & $2.390 E+12$ \\
\hline $1.25 \mathrm{E}+00$ & $1.826 \mathrm{E}+11$ & $1.741 \mathrm{E}+11$ & $1.658 \mathrm{E}+11$ & $1.581 E+11$ & $1.507 \mathrm{E}+11$ & $1.436 \mathrm{E}+11$ & $1.369 \mathrm{E}+11$ \\
\hline $1.75 \mathrm{E}+00$ & $5.913 \mathrm{E}+11$ & +11 & $E+11$ & $5.117 \mathrm{E}+11$ & $4.878 \mathrm{E}+11$ & $4.649 \mathrm{E}+11$ & $4.431 \mathrm{E}+11$ \\
\hline $2.25 E+00$ & 2.96 & $3.567 \mathrm{E}+05$ & $4.197 \mathrm{E}+05$ & $4.855 \mathrm{E}+05$ & $5.540 \mathrm{E}+05$ & $6.251 \mathrm{E}+05$ & $6.988 \mathrm{E}+05$ \\
\hline $2.75 E+00$ & $5.961 \mathrm{E}+12$ & $5.682 \mathrm{E}+12$ & $5.411 \mathrm{E}+12$ & $5.157 \mathrm{E}+12$ & $4.914 E+12$ & $4.683 \mathrm{E}+12$ & $4.463 E+12$ \\
\hline $3.50 E+00$ & $2.432 E+04$ & $2.298 \mathrm{E}+04$ & $2.180 E+04$ & $2.077 E+04$ & $1.986 \mathrm{E}+04$ & $1.907 \mathrm{E}+04$ & +04 \\
\hline $5.00 \mathrm{E}+00$ & $7.566 \mathrm{E}+03$ & $E+03$ & +03 & $6.085 \mathrm{E}+03$ & $5.695 \mathrm{E}+03$ & $5.344 \mathrm{E}+03$ & $5.028 \mathrm{E}+03$ \\
\hline $7.00 E+00$ & 5.81 & $5.310 \mathrm{E}+02$ & $4.866 \mathrm{E}+02$ & $4.480 \mathrm{E}+02$ & $4.141 E+02$ & $3.844 \mathrm{E}+02$ & $3.580 \mathrm{E}+02$ \\
\hline $1.10 \mathrm{E}+01$ & $4.755 \mathrm{E}+01$ & $4.255 \mathrm{E}+01$ & $3.827 \mathrm{E}+01$ & $3.462 E+01$ & $3.147 \mathrm{E}+01$ & $2.876 E+01$ & $2.640 \mathrm{E}+01$ \\
\hline Sum & $5.550 \mathrm{E}+13$ & $5.296 \mathrm{E}+13$ & $5.050 \mathrm{E}+13$ & $4.818 \mathrm{E}+13$ & $4.597 E+13$ & $4.386 \mathrm{E}+13$ & $4.185 \mathrm{E}+13$ \\
\hline
\end{tabular}

The basis for the ORIGEN2 simulation is a Seed assembly. The initial fissile loading of the simulated assembly is $16,892.84 \mathrm{~g}$. which is approximately $2 \%$ greater than the actual initial fissile loading. The simulated burnup is 10,269 MWd for the assembly.

Table B-3 Calculated Photon Spectra from Fission Products in Seed Fuel [Ref. 19]

\begin{tabular}{|c|c|c|c|c|c|c|c|}
\hline \multirow{2}{*}{$\begin{array}{c}\text { Mean } \\
\text { Photon } \\
\text { Energy } \\
(\text { MeV) }\end{array}$} & \multicolumn{7}{|c|}{$\begin{array}{l}\text { Calculated Photon Spectrum }{ }^{\text {a }} \text { from Fission Products as of Year } \\
\text { (Photon/s) }\end{array}$} \\
\hline & 2000 & 2005 & 2010 & 2015 & 2020 & 2025 & 2030 \\
\hline $1.50 \mathrm{E}-02$ & $1.268 E+15$ & $1.123 E+15$ & $9.958 \mathrm{E}+14$ & $8.831 \mathrm{E}+14$ & $7.833 E+14$ & $6.950 \mathrm{E}+14$ & $6.168 \mathrm{E}+14$ \\
\hline $2.50 \mathrm{E}-02$ & $2.650 E+14$ & $2.340 E+14$ & $2.073 E+14$ & $1.838 \mathrm{E}+14$ & $1.630 \mathrm{E}+14$ & $1.446 \mathrm{E}+14$ & $1.284 E+14$ \\
\hline $3.75 \mathrm{E}-02$ & $2.273 E+14$ & $2.006 \mathrm{E}+14$ & $1.774 \mathrm{E}+14$ & $1.572 \mathrm{E}+14$ & $1.393 E+14$ & $1.236 \mathrm{E}+14$ & $1.097 \mathrm{E}+14$ \\
\hline $5.75 \mathrm{E}-02$ & $2.467 E+14$ & $2.185 E+14$ & $1.936 E+14$ & $1.717 E+14$ & $1.522 E+14$ & $1.351 \mathrm{E}+14$ & $1.199 \mathrm{E}+14$ \\
\hline $8.50 \mathrm{E}-02$ & $1.495 E+14$ & $1.322 \mathrm{E}+14$ & $1.170 \mathrm{E}+14$ & $1.037 \mathrm{E}+14$ & $9.200 \mathrm{E}+13$ & $8.162 E+13$ & $7.243 \mathrm{E}+13$ \\
\hline $1.25 \mathrm{E}-01$ & $1.020 \mathrm{E}+14$ & $8.913 E+13$ & $7.820 \mathrm{E}+13$ & $6.882 E+13$ & $6.069 \mathrm{E}+13$ & $5.362 \mathrm{E}+13$ & $4.743 E+13$ \\
\hline $2.25 \mathrm{E}-01$ & $1.291 \mathrm{E}+14$ & $1.143 E+14$ & $1.012 E+14$ & $8.970 E+13$ & $7.953 E+13$ & $7.054 E+13$ & $6.258 \mathrm{E}+13$ \\
\hline $3.75 \mathrm{E}-01$ & $5.661 E+13$ & $4.979 E+13$ & $4.405 E+13$ & $3.906 E+13$ & $3.465 E+13$ & $3.075 \mathrm{E}+13$ & $2.729 \mathrm{E}+13$ \\
\hline $5.75 \mathrm{E}-01$ & $8.539 E+14$ & $7.568 \mathrm{E}+14$ & $6.732 E+14$ & $5.994 \mathrm{E}+14$ & $5.338 \mathrm{E}+14$ & $4.754 \mathrm{E}+14$ & $4.235 \mathrm{E}+14$ \\
\hline $8.50 \mathrm{E}-01$ & $1.828 E+13$ & $E+13$ & $1.001 E+13$ & $8.202 E+12$ & $6.859 \mathrm{E}+12$ & $5.814 \mathrm{E}+12$ & $4.979 E+12$ \\
\hline $1.25 \mathrm{E}+00$ & $1.010 E+13$ & $7.310 \mathrm{E}+12$ & $5.450 \mathrm{E}+12$ & $4.156 \mathrm{E}+12$ & $3.236 \mathrm{E}+12$ & $2.570 \mathrm{E}+12$ & $2.079 E+12$ \\
\hline $1.75 \mathrm{E}+00$ & $4.397 E+11$ & $3.450 \mathrm{E}+11$ & $2.759 E+11$ & $2.247 E+11$ & $1.859 \mathrm{E}+11$ & $1.560 \mathrm{E}+11$ & $1.324 \mathrm{E}+11$ \\
\hline $2.25 E+00$ & $3.738 \mathrm{E}+07$ & $2.293 E+07$ & $=07$ & $1.791 \mathrm{E}+07$ & $1.590 \mathrm{E}+07$ & $1.412 \mathrm{E}+07$ & $1.253 E+07$ \\
\hline $2.75 \mathrm{E}+00$ & $5.356 \mathrm{E}+05$ & $1.706 \mathrm{E}+04$ & $5.466 \mathrm{E}+02$ & $1.754 \mathrm{E}+01$ & $5.626 \mathrm{E}-01$ & $1.818 \mathrm{E}-02$ & $6.824 \mathrm{E}-04$ \\
\hline $3.50 \mathrm{E}+00$ & $6.904 E+04$ & $2.219 E+03$ & $7.131 \mathrm{E}+01$ & $2.292 \mathrm{E}+00$ & $7.358 \mathrm{E}-02$ & $2.437 \mathrm{E}-03$ & 1.507E-04 \\
\hline $5.00 \mathrm{E}+00$ & $2.226 \mathrm{E}-05$ & $2.227 \mathrm{E}-05$ & $2.227 \mathrm{E}-05$ & $2.227 \mathrm{E}-05$ & $2.227 \mathrm{E}-05$ & $2.227 \mathrm{E}-05$ & $2.227 \mathrm{E}-05$ \\
\hline $7.00 \mathrm{E}+00$ & $1.444 \mathrm{E}-06$ & $1.445 \mathrm{E}-06$ & $1.445 \mathrm{E}-06$ & $1.445 \mathrm{E}-06$ & $1.445 \mathrm{E}-06$ & $1.445 \mathrm{E}-06$ & $1.445 \mathrm{E}-06$ \\
\hline $1.10 \mathrm{E}+01$ & $9.134 \mathrm{E}-08$ & $9.138 \mathrm{E}-08$ & $9.139 \mathrm{E}-08$ & $9.139 \mathrm{E}-08$ & $9.139 \mathrm{E}-08$ & $9.139 \mathrm{E}-08$ & $9.139 \mathrm{E}-08$ \\
\hline Sum & $3.327 \mathrm{E}+15$ & $2.939 \mathrm{E}+15$ & $2.604 \mathrm{E}+15$ & $2.309 E+15$ & $2.049 \mathrm{E}+15$ & $1.819 \mathrm{E}+15$ & $1.615 \mathrm{E}+15$ \\
\hline
\end{tabular}

'The basis for the ORIGEN2 simulation is a Seed assembly. The initial fissile loading of the simulated assembly is $16,892.84 \mathrm{~g}$, which is approximately $2 \%$ greater than the actual initial fissile loading. The simulated burnup is $10,269.14$ MWd for the assembly. 
Table B-4 $\alpha, N$ Neutron Sources for a Shippingport LWBR Seed Assembly * [Ref. 19]

\begin{tabular}{|c|c|c|c|c|c|c|c|}
\hline \multirow{3}{*}{ Nuclide } & \multicolumn{7}{|c|}{$(\alpha, \mathbf{n}) \begin{array}{c}\text { Neutron Source } \\
\text { (Neutron/s) }\end{array}$} \\
\cline { 2 - 8 } & 2000 & 2005 & 2010 & 2015 & 2020 & 2025 & 2030 \\
\hline${ }^{212} \mathrm{Bi}$ & $5.911 \mathrm{E}+07$ & $5.634 \mathrm{E}+07$ & $5.366 \mathrm{E}+07$ & $5.114 \mathrm{E}+07$ & $4.873 \mathrm{E}+07$ & $4.644 \mathrm{E}+07$ & $4.426 \mathrm{E}+07$ \\
\hline${ }^{212} \mathrm{Po}$ & $5.131 \mathrm{E}+08$ & $4.891 \mathrm{E}+08$ & $4.658 \mathrm{E}+08$ & $4.439 \mathrm{E}+08$ & $4.231 \mathrm{E}+08$ & $4.032 \mathrm{E}+08$ & $3.842 \mathrm{E}+08$ \\
\hline${ }^{213} \mathrm{Po}$ & $2.337 \mathrm{E}+05$ & $2.865 \mathrm{E}+05$ & $3.394 \mathrm{E}+05$ & $3.922 \mathrm{E}+05$ & $4.451 \mathrm{E}+05$ & $4.978 \mathrm{E}+05$ & $5.506 \mathrm{E}+05$ \\
\hline${ }^{210} \mathrm{Po}$ & $2.152 \mathrm{E}+07$ & $2.052 \mathrm{E}+07$ & $1.954 \mathrm{E}+07$ & $1.862 \mathrm{E}+07$ & $1.775 \mathrm{E}+07$ & $1.691 \mathrm{E}+07$ & $1.612 \mathrm{E}+07$ \\
\hline${ }^{220} \mathrm{Rn}$ & $7.493 \mathrm{E}+06$ & $7.143 \mathrm{E}+06$ & $6.802 \mathrm{E}+06$ & $6.483 \mathrm{E}+06$ & $6.178 \mathrm{E}+06$ & $5.888 \mathrm{E}+06$ & $5.611 \mathrm{E}+06$ \\
\hline${ }^{2{ }^{24} \mathrm{Ra}}$ & $1.822 \mathrm{E}+06$ & $1.736 \mathrm{E}+06$ & $1.654 \mathrm{E}+06$ & $1.576 \mathrm{E}+06$ & $1.502 \mathrm{E}+06$ & $1.431 \mathrm{E}+06$ & $1.364 \mathrm{E}+06$ \\
\hline${ }^{228} \mathrm{Th}$ & $9.236 \mathrm{E}+05$ & $8.811 \mathrm{E}+05$ & $8.398 \mathrm{E}+05$ & $8.004 \mathrm{E}+05$ & $7.628 \mathrm{E}+05$ & $7.269 \mathrm{E}+05$ & $6.928 \mathrm{E}+05$ \\
\hline${ }^{232} \mathrm{U}$ & $6.948 \mathrm{E}+05$ & $6.621 \mathrm{E}+05$ & $6.310 \mathrm{E}+05$ & $6.014 \mathrm{E}+05$ & $5.731 \mathrm{E}+05$ & $5.462 \mathrm{E}+05$ & $5.205 \mathrm{E}+05$ \\
\hline Sum & $6.052 \mathrm{E}+08$ & $5.770 \mathrm{E}+08$ & $5.496 \mathrm{E}+08$ & $5.239 \mathrm{E}+08$ & $4.994 \mathrm{E}+08$ & $4.760 \mathrm{E}+08$ & $4.537 \mathrm{E}+08$ \\
\hline
\end{tabular}

"The basis for the ORIGEN2 simulation is a Seed assembly. The initial fissile loading of the simulated assembly is $16,892.84 \mathrm{~g}$, which is approximately $2 \%$ greater than the actual initial fissile loading. The simulated burnup is 10,269.14 MWd for the assembly.

Table B-5 Calculated Spontaneous Fission Neutron Source for Seed Fuel [Ref. 19]

\begin{tabular}{|c|c|c|c|c|c|c|c|}
\hline \multirow{2}{*}{ Nuclide } & \multicolumn{7}{|c|}{$\begin{array}{c}\text { Spontaneous Fission Neutron Source }{ }^{\mathrm{a}} \text { as of Year } \\
\text { (Neutron/s) }\end{array}$} \\
\cline { 2 - 8 } & 2000 & 2005 & 2010 & 2015 & 2020 & 2025 & 2030 \\
\hline${ }^{232} \mathrm{U}$ & $2.327 \mathrm{E}+01$ & $2.218 \mathrm{E}+01$ & $2.114 \mathrm{E}+01$ & $2.015 \mathrm{E}+01$ & $1.920 \mathrm{E}+01$ & $1.830 \mathrm{E}+01$ & $1.744 \mathrm{E}+01$ \\
\hline${ }^{238} \mathrm{Pu}$ & $7.763 \mathrm{E}+02$ & $7.464 \mathrm{E}+02$ & $7.175 \mathrm{E}+02$ & $6.898 \mathrm{E}+02$ & $6.632 \mathrm{E}+02$ & $6.376 \mathrm{E}+02$ & $6.130 \mathrm{E}+02$ \\
\hline${ }^{240} \mathrm{Pu}$ & $6.623 \mathrm{E}+02$ & $6.625 \mathrm{E}+02$ & $6.626 \mathrm{E}+02$ & $6.626 \mathrm{E}+02$ & $6.626 \mathrm{E}+02$ & $6.625 \mathrm{E}+02$ & $6.623 \mathrm{E}+02$ \\
\hline${ }^{242} \mathrm{Pu}$ & $1.846 \mathrm{E}+02$ & $1.847 \mathrm{E}+02$ & $1.847 \mathrm{E}+02$ & $1.847 \mathrm{E}+02$ & $1.847 \mathrm{E}+02$ & $1.847 \mathrm{E}+02$ & $1.847 \mathrm{E}+02$ \\
\hline${ }^{242} \mathrm{Cm}$ & $8.835 \mathrm{E}+01$ & $8.638 \mathrm{E}+01$ & $8.429 \mathrm{E}+01$ & $8.239 \mathrm{E}+01$ & $8.054 \mathrm{E}+01$ & $7.872 \mathrm{E}+01$ & $7.695 \mathrm{E}+01$ \\
\hline${ }^{244} \mathrm{Cm}$ & $3.883 \mathrm{E}+04$ & $3.207 \mathrm{E}+04$ & $2.648 \mathrm{E}+04$ & $2.187 \mathrm{E}+04$ & $1.806 \mathrm{E}+04$ & $1.491 \mathrm{E}+04$ & $1.232 \mathrm{E}+04$ \\
\hline${ }^{246} \mathrm{Cm}$ & $1.371 \mathrm{E}+02$ & $1.370 \mathrm{E}+02$ & $1.369 \mathrm{E}+02$ & $1.368 \mathrm{E}+02$ & $1.367 \mathrm{E}+02$ & $1.366 \mathrm{E}+02$ & $1.365 \mathrm{E}+02$ \\
\hline Sum & $4.072 \mathrm{E}+04$ & $3.392 \mathrm{E}+04$ & $2.830 \mathrm{E}+04$ & $2.366 \mathrm{E}+04$ & $1.982 \mathrm{E}+04$ & $1.665 \mathrm{E}+04$ & $1.402 \mathrm{E}+04$ \\
\hline
\end{tabular}

"The basis for the ORIGEN2 simulation is a Seed assembly. The initial fissile loading of the simulated assembly is $16,892.84 \mathrm{~g}$, which is approximately $2 \%$ greater than the actual initial fissile loading. The simulated burnup is $10,269.14 \mathrm{MWd}$ for the assembly.

\section{Decay Heat}

The estimated isotopic activities through the year 2030 of one SNF canister packed with one LWBR seed fuel assembly [Ref. 6, p. 43] are given in Table B-6. The decay heat output is shown in Table B-7 and portrayed graphically in Figure B-1.

Comparative BOL and EOL fissile loadings (nominal per assembly) are shown in Table B-8 for a single seed assembly. BOL values only are also shown for blanket Type II and III configurations in Tables B-9 and B-10 respectively. 
Table B-6 Calculated Isotopic Activity of the Seed Fuel by Year

[Ref. 19]

\begin{tabular}{|c|c|c|c|c|c|c|c|}
\hline \multirow[b]{2}{*}{ Nuclide } & \multicolumn{7}{|c|}{$\begin{array}{l}\text { Isotopic Activity as of Year }{ }^{a} \\
\text { (Ci) }\end{array}$} \\
\hline & 2000 & 2005 & 2010 & 2015 & 2020 & 2025 & 2030 \\
\hline${ }^{3} \mathrm{H}$ & $5.813 \mathrm{E}+01$ & $4.391 \mathrm{E}+01$ & $3.317 \mathrm{E}+01$ & $2.505 \mathrm{E}+01$ & $1.892 \mathrm{E}+01$ & $1.429 \mathrm{E}+01$ & $1.079 E+01$ \\
\hline${ }^{10} \mathrm{Be}$ & $2.394 \mathrm{E}-06$ & $2.394 \mathrm{E}-06$ & $2.394 \mathrm{E}-06$ & $2.394 \mathrm{E}-06$ & $2.394 \mathrm{E}-06$ & $2.394 \mathrm{E}-06$ & $2.394 \mathrm{E}-06$ \\
\hline${ }^{14} \mathrm{C}$ & $8.892 \mathrm{E}-01$ & $8.886 \mathrm{E}-01$ & $8.881 \mathrm{E}-01$ & $8.875 \mathrm{E}-01$ & $8.870 \mathrm{E}-01$ & $8.865 E-01$ & $8.859 \mathrm{E}-01$ \\
\hline${ }^{\circ} \mathrm{Cl}$ & $1.859 \mathrm{E}-02$ & $1.859 \mathrm{E}-02$ & 1.859E-02 & $1.859 \mathrm{E}-02$ & $1.859 \mathrm{E}-02$ & $1.859 \mathrm{E}-02$ & $1.859 \mathrm{E}-02$ \\
\hline${ }^{\mathrm{T}} \mathrm{Cr}$ & $3.799 \mathrm{E}-68$ & $5.515 \mathrm{E}-88$ & $8.007-108$ & $1.162-127$ & $1.646-147$ & $2.389-167$ & $3.469-187$ \\
\hline${ }^{34} \mathrm{Mn}$ & $1.768 \mathrm{E}-05$ & $3.080 \mathrm{E}-07$ & $5.365 \mathrm{E}-09$ & $9.345 \mathrm{E}-11$ & $1.624 \mathrm{E}-12$ & $2.829 E-14$ & $4.928 \mathrm{E}-16$ \\
\hline${ }^{55} \mathrm{Fe}$ & $2.141 E+00$ & $5.648 \mathrm{E}-01$ & $1.490 \mathrm{E}-01$ & $3.928 \mathrm{E}-02$ & $1.035 \mathrm{E}-02$ & $2.731 \mathrm{E}-03$ & $7.202 \mathrm{E}-04$ \\
\hline${ }^{59} \mathrm{Fe}$ & $4.746 \mathrm{E}-43$ & $2.892 \mathrm{E}-55$ & $1.762 \mathrm{E}-67$ & $1.074 \mathrm{E}-79$ & $6.444 \mathrm{E}-92$ & $3.927-104$ & $2.393-116$ \\
\hline${ }^{\circ} \mathrm{Co}$ & $8.183 E+01$ & $4.240 \mathrm{E}+01$ & $2.197 \mathrm{E}+01$ & $1.138 E+01$ & $5.894 \mathrm{E}+00$ & $3.054 E+00$ & $1.582 E+00$ \\
\hline${ }^{59} \mathrm{Ni}$ & $6.359 \mathrm{E}-02$ & $6.359 \mathrm{E}-02$ & $6.359 \mathrm{E}-02$ & $6.358 \mathrm{E}-02$ & $6.358 \mathrm{E}-02$ & $6.358 \mathrm{E}-02$ & $6.358 \mathrm{E}-02$ \\
\hline${ }^{3} \mathrm{Ni}$ & $7.751 E+00$ & $7.465 \mathrm{E}+00$ & $7.189 \mathrm{E}+00$ & $6.923 E+00$ & $6.667 \mathrm{E}+00$ & $6.421 E+00$ & $6.183 E+00$ \\
\hline${ }^{55} \mathrm{Zn}$ & $3.474 \mathrm{E}-07$ & $1.936 \mathrm{E}-09$ & $1.078 \mathrm{E}-11$ & $6.008 \mathrm{E}-14$ & $3.338 \mathrm{E}-16$ & $1.860 \mathrm{E}-18$ & $1.036 \mathrm{E}-20$ \\
\hline${ }^{79} \mathrm{Se}$ & $3.637 \mathrm{E}-01$ & $3.637 \mathrm{E}-01$ & $3.637 \mathrm{E}-01$ & $3.637 \mathrm{E}-01$ & $3.637 \mathrm{E}-01$ & $3.636 \mathrm{E}-01$ & $3.636 \mathrm{E}-01$ \\
\hline${ }^{85} \mathrm{Kr}$ & $1.985 \mathrm{E}+03$ & $1.437 \mathrm{E}+03$ & $1.040 \mathrm{E}+03$ & $7.528 \mathrm{E}+02$ & $5.448 \mathrm{E}+02$ & $3.943 E+02$ & $2.854 \mathrm{E}+02$ \\
\hline${ }^{87} \mathrm{Rb}$ & $1.429 \mathrm{E}-05$ & $1.429 \mathrm{E}-05$ & $1.429 \mathrm{E}-05$ & $1.429 \mathrm{E}-05$ & $1.429 \mathrm{E}-05$ & $1.429 \mathrm{E}-05$ & $1.429 \mathrm{E}-05$ \\
\hline${ }^{89} \mathrm{Sr}$ & $6.909 E-34$ & $8.998 \mathrm{E}-45$ & $1.172 \mathrm{E}-55$ & $1.526 \mathrm{E}-66$ & $1.960 \mathrm{E}-77$ & $2.553 \mathrm{E}-88$ & $3.325 \mathrm{E}-99$ \\
\hline${ }^{50} \mathrm{Sr}$ & $2.321 \mathrm{E}+04$ & $2.061 E+04$ & $1.830 E+04$ & $1.624 E+04$ & $1.442 \mathrm{E}+04$ & $1.280 \mathrm{E}+04$ & $1.137 \mathrm{E}+04$ \\
\hline${ }^{50} \mathrm{Y}$ & $2.322 \mathrm{E}+04$ & $2.061 E+04$ & $1.830 \mathrm{E}+04$ & $1.625 \mathrm{E}+04$ & $1.442 E+04$ & $1.281 \mathrm{E}+04$ & $1.137 \mathrm{E}+04$ \\
\hline${ }^{91} Y$ & $1.401 \mathrm{E}-28$ & $2 \mathrm{E}-38$ & $2.271 E-47$ & $9.145 \mathrm{E}-57$ & $3.639 \mathrm{E}-66$ & $1.464 \mathrm{E}-75$ & $5.897 \mathrm{E}-85$ \\
\hline${ }^{93} \mathrm{Zr}$ & $=-01$ & $8.496 \mathrm{E}-01$ & $8.496 \mathrm{E}-01$ & $8.496 \mathrm{E}-01$ & $8.496 \mathrm{E}-01$ & $8.496 \mathrm{E}-01$ & $8.495 \mathrm{E}-01$ \\
\hline${ }^{95} \mathrm{Zr}$ & $1.008 \mathrm{E}-25$ & $2.583 E-34$ & $6.620 \mathrm{E}-43$ & $1.697 \mathrm{E}-51$ & $4.302 \mathrm{E}-60$ & $1.103 \mathrm{E}-68$ & $2.826 \mathrm{E}-77$ \\
\hline$-93 m \mathrm{Nb}$ & -01 & $\mathrm{E}-01$ & $6.355 \mathrm{E}-01$ & $6.741 \mathrm{E}-01$ & $7.040 \mathrm{E}-01$ & $7.272 \mathrm{E}-01$ & $7.452 \mathrm{E}-01$ \\
\hline $94 \mathrm{Nb}$ & -02 & $\mathrm{E}-02$ & $2.303 \mathrm{E}-02$ & $2.303 E-02$ & $2.303 \mathrm{E}-02$ & $2.302 \mathrm{E}-02$ & $2.302 \mathrm{E}-02$ \\
\hline${ }^{95} \mathrm{Nb}$ & $2.238 \mathrm{E}-25$ & $5.734 E-34$ & -42 & $3.767 \mathrm{E}-51$ & $9.551 \mathrm{E}-60$ & $2.448 \mathrm{E}-68$ & $6.274 \mathrm{E}-77$ \\
\hline $95 \mathrm{Nb}$ & $7.477 \mathrm{E}-28$ & $\mathrm{E}-36$ & $4.911 E-45$ & $1.259 \mathrm{E}-53$ & E-62 & $8.179 E-71$ & $2.097 \mathrm{E}-79$ \\
\hline${ }^{93} \mathrm{Mo}$ & -03 & $\mathrm{E}-03$ & $4.186 \mathrm{E}-03$ & $4.181 \mathrm{E}-03$ & $4.177 \mathrm{E}-03$ & $4.173 \mathrm{E}-03$ & $4.169 \mathrm{E}-03$ \\
\hline${ }^{-99} \mathrm{TC}$ & $3.341 E+00$ & $3.341 E+00$ & $3.341 \mathrm{E}+00$ & $3.341 E+00$ & $3.340 \mathrm{E}+00$ & $3.340 E+00$ & $3.340 E+00$ \\
\hline${ }^{103} \mathrm{Ru}$ & $1.827 \mathrm{E}-45$ & $1.856 \mathrm{E}-59$ & $1.886 \mathrm{E}-73$ & $1.916 \mathrm{E}-87$ & $1.913-101$ & $1.944-115$ & $1.976-129$ \\
\hline${ }^{106} \mathrm{Ru}$ & $E-02$ & $2.135 \mathrm{E}-03$ & $6.860 \mathrm{E}-05$ & $2.205 \mathrm{E}-06$ & $7.072 \mathrm{E}-08$ & $2.273 E-09$ & $7.303 \mathrm{E}-11$ \\
\hline${ }^{70314} \mathrm{Rh}$ & $E-45$ & $1.673 \mathrm{E}-59$ & $1.700 \mathrm{E}-73$ & $1.728 \mathrm{E}-87$ & $1.725-101$ & $1.753-115$ & $1.781-129$ \\
\hline${ }^{106} \mathrm{Rh}$ & $6.643 \mathrm{E}-02$ & $2.135 \mathrm{E}-03$ & & $2.205 \mathrm{E}-06$ & $7.072 \mathrm{E}-08$ & $2.273 \mathrm{E}-09$ & $7.303 \mathrm{E}-11$ \\
\hline${ }^{107} \mathrm{Pd}$ & 03 & -03 & -03 & $3.543 \mathrm{E}-03$ & $3.543 \mathrm{E}-03$ & $3.543 \mathrm{E}-03$ & $3.543 \mathrm{E}-03$ \\
\hline $110 \mathrm{Ag}$ & -08 & $E-10$ & $9.210 \mathrm{E}-13$ & $5.814 \mathrm{E}-15$ & $3.660 \mathrm{E}-17$ & $2.311 \mathrm{E}-19$ & $1.459 \mathrm{E}-21$ \\
\hline${ }^{710 m} \mathrm{Ag}$ & $1.737 \mathrm{E}-06$ & $1.097 \mathrm{E}-08$ & $6.924 \mathrm{E}-11$ & $4.371 \mathrm{E}-13$ & $2.752 E-15$ & $1.738 \mathrm{E}-17$ & $1.097 \mathrm{E}-19$ \\
\hline$m \mathrm{Ag}$ & +00 & +00 & $0.000 \mathrm{E}+00$ & $0.000 \mathrm{E}+00$ & $0.000 \mathrm{E}+00$ & $0.000 \mathrm{E}+00$ & $0.000 \mathrm{E}+00$ \\
\hline$\pi 3 \mathrm{Cd}$ & & & 1.223 & $9.646 \mathrm{E}-01$ & $7.606 \mathrm{E}-01$ & $5.998 \mathrm{E}-01$ & $4.730 \mathrm{E}-01$ \\
\hline${ }^{113} \mathrm{Cd}$ & +00 & $E+00$ & $0.000 E+00$ & $0.000 \mathrm{E}+00$ & $0.000 \mathrm{E}+00$ & $0.000 E+00$ & $0.000 \mathrm{E}+00$ \\
\hline गालd & $1.688 \mathrm{E}-42$ & E-55 & $3.760 \mathrm{E}-67$ & $1.775 E-79$ & $\mathrm{E}-92$ & $3.892-104$ & $1.837-116$ \\
\hline$\pi 4 \frac{\pi}{\ln }$ & -39 & E-50 & $4.536 \mathrm{E}-61$ & $3.589 \mathrm{E}-72$ & $2.802 \mathrm{E}-83$ & $2.218 \mathrm{E}-94$ & $1.756-105$ \\
\hline $74 / \sqrt{1 / n}$ & E-39 & $E-50$ & $4.739 E-61$ & $3.751 \mathrm{E}-72$ & $2.928 \mathrm{E}-83$ & $2.318 \mathrm{E}-94$ & $1.834-105$ \\
\hline & $1.186 \mathrm{E}-46$ & $5.597 \mathrm{E}-59$ & $2.641 \mathrm{E}-71$ & $1.247 \mathrm{E}-83$ & $5.793 \mathrm{E}-96$ & $2.734-108$ & $1.290-120$ \\
\hline & -05 & $1.676 \mathrm{E}-07$ & $9.572 \mathrm{E}-10$ & $5.465 E-12$ & $E-14$ & $1.777 \mathrm{E}-16$ & $1.014 \mathrm{E}-18$ \\
\hline${ }^{2} \pi M S n$ & 4.719E-01 & $4.403 \mathrm{E}-01$ & $4.109 \mathrm{E}-01$ & $3.833 \mathrm{E}-01$ & $3.576 \mathrm{E}-01$ & $3.336 \mathrm{E}-01$ & $3.113 \mathrm{E}-01$ \\
\hline${ }^{123} \mathrm{Sn}$ & -13 & $2.575 E-17$ & $1.429 \mathrm{E}-21$ & $7.936 \mathrm{E}-26$ & $4.381 \mathrm{E}-30$ & $2.433 \mathrm{E}-34$ & $1.351 \mathrm{E}-38$ \\
\hline & $0.000 E+00$ & $0.000 \mathrm{E}+00$ & $0.000 \mathrm{E}+00$ & $0.000 \mathrm{E}+00$ & $0.000 E+00$ & $0.000 E+00$ & $0.000 E+00$ \\
\hline $\mathrm{Sn}$ & $4.092 \mathrm{E}-01$ & $4.092 \mathrm{E}-01$ & $4.092 \mathrm{E}-01$ & $4.092 \mathrm{E}-01$ & E-01 & $4.092 \mathrm{E}-01$ & $4.091 \mathrm{E}-01$ \\
\hline $\mathrm{Sb}$ & $8.290 \mathrm{E}-31$ & $6 E-40$ & -49 & $3.344 E-58$ & $2.443 E-67$ & $1.805 \mathrm{E}-76$ & $1.334 \mathrm{E}-85$ \\
\hline${ }^{125} \mathrm{Sb}$ & $6.293 E+01$ & $1.801 \mathrm{E}+01$ & $5.155 \mathrm{E}+00$ & $1.475 E+00$ & $4.220 \mathrm{E}-01$ & $1.208 \mathrm{E}-01$ & $3.457 \mathrm{E}-02$ \\
\hline $\mathrm{Sb}$ & $5.729 \mathrm{E}-02$ & $5.729 \mathrm{E}-02$ & $5.729 \mathrm{E}-02$ & $5.729 \mathrm{E}-02$ & $5.728 \mathrm{E}-02$ & $5.728 \mathrm{E}-02$ & $5.728 \mathrm{E}-02$ \\
\hline
\end{tabular}


Table B-6 Calculated Isotopic Activity of the Seed Fuel by Year [Ref. 19] (cont'd)

\begin{tabular}{|c|c|c|c|c|c|c|c|}
\hline \multirow[b]{2}{*}{ Nuclide } & \multicolumn{7}{|c|}{$\begin{array}{l}\text { Isotopic Activity as of Year } \\
\text { (Ci) }\end{array}$} \\
\hline & 2000 & 2005 & 2010 & 2015 & 2020 & 2025 & 2030 \\
\hline & $4.092 \mathrm{E}-01$ & $4.092 \mathrm{E}-01$ & $4.092 \mathrm{E}-01$ & $4.092 \mathrm{E}-01$ & $4.092 \mathrm{E}-01$ & $4.092 \mathrm{E}-01$ & $4.091 \mathrm{E}-01$ \\
\hline & $1.793 \mathrm{E}-16$ & $4.577 \mathrm{E}-21$ & $1.168 \mathrm{E}-25$ & $2.982 \mathrm{E}-30$ & $7.565 \mathrm{E}-35$ & $1.931 \mathrm{E}-39$ & $4.928 E-44$ \\
\hline${ }^{5 \mathrm{Te}}$ & $.536 E+01$ & $4.395 \mathrm{E}+00$ & $1.258 \mathrm{E}+00$ & $3.600 \mathrm{E}-01$ & $1.030 \mathrm{E}-01$ & $2.947 \mathrm{E}-02$ & $8.434 E-03$ \\
\hline${ }^{7 \mathrm{Te}}$ & $5.869 \mathrm{E}-15$ & $5.319 \mathrm{E}-20$ & 4.821E-25 & $4.369 \mathrm{E}-30$ & $3.935 \mathrm{E}-35$ & $3.566 \mathrm{E}-40$ & $E-45$ \\
\hline${ }^{\mathrm{M}} \mathrm{Te}$ & $5.992 \mathrm{E}-15$ & $5.431 \mathrm{E}-20$ & $4.922 \mathrm{E}-25$ & $4.461 \mathrm{E}-30$ & $4.017 \mathrm{E}-35$ & $3.641 E-40$ & $3.299 \mathrm{E}-45$ \\
\hline${ }^{229} \mathrm{Te}$ & $8.233 E-55$ & $3.596 \mathrm{E}-71$ & $1.570 \mathrm{E}-87$ & $6.858-104$ & $2.934-120$ & $1.282-136$ & $5.597-153$ \\
\hline${ }^{2517} \mathrm{Te}$ & $1.265 \mathrm{E}-54$ & $5.524 \mathrm{E}-71$ & $2.412 \mathrm{E}-87$ & $1.054-103$ & $4.508-120$ & $1.969-136$ & $8.598-153$ \\
\hline & $1.628 \mathrm{E}-02$ & $1.628 \mathrm{E}-02$ & $1.628 \mathrm{E}-02$ & $1.628 \mathrm{E}-02$ & $1.628 \mathrm{E}-02$ & $1.628 \mathrm{E}-02$ & $1.628 \mathrm{E}-02$ \\
\hline & $0.000 E+00$ & $0.000 \mathrm{E}+00$ & $0.000 \mathrm{E}+00$ & $0.000 \mathrm{E}+00$ & $0.000 \mathrm{E}+00$ & $0.000 \mathrm{E}+00$ & $0.000 \mathrm{E}+00$ \\
\hline${ }^{4} \mathrm{Xe}$ & $0.000 \mathrm{E}+00$ & $0.000 \mathrm{E}+00$ & $0.000 \mathrm{E}+00$ & $0.000 E+00$ & $0.000 \mathrm{E}+00$ & $0.000 \mathrm{E}+00$ & $0.000 \mathrm{E}+00$ \\
\hline${ }^{33} \mathrm{Xe}$ & $0.000 \mathrm{E}+00$ & $0.000 \mathrm{E}+00$ & $0.000 \mathrm{E}+00$ & $0.000 E+00$ & $0.000 \mathrm{E}+00$ & $0.000 E+00$ & $E+00$ \\
\hline${ }^{3+4 s}$ & $9.226 \mathrm{E}+01$ & $1.719 E+01$ & $3.201 \mathrm{E}+00$ & $5.962 \mathrm{E}-01$ & $1.110 \mathrm{E}-01$ & $2.067 \mathrm{E}-02$ & -03 \\
\hline${ }^{135} \mathrm{Cs}$ & $2.941 \mathrm{E}-01$ & $2.941 \mathrm{E}-01$ & $2.941 \mathrm{E}-01$ & $2.941 \mathrm{E}-01$ & $2.941 \mathrm{E}-01$ & $2.941 E-01$ & $1 \mathrm{E}-01$ \\
\hline${ }^{136} \mathrm{Cs}$ & 0.00 & $0.000 E+00$ & $0.000 E+00$ & $0.000 \mathrm{E}+00$ & $0 \mathrm{E}+00$ & $0.000 \mathrm{E}+00$ & $0.000 \mathrm{E}+00$ \\
\hline${ }^{73} \mathrm{Cs}$ & 2.27 & $E+04$ & $1.802 E+04$ & $1.605 \mathrm{E}+04$ & $0 \mathrm{E}+04$ & $1.274 \mathrm{E}+04$ & $E+04$ \\
\hline${ }^{136 \mathrm{~m}} \mathrm{Ba}$ & $0.000 E+00$ & $0.000 \mathrm{E}+00$ & $0.000 \mathrm{E}+00$ & $0.000 \mathrm{E}+00$ & $0.000 \mathrm{E}+00$ & $0.000 \mathrm{E}+00$ & +00 \\
\hline${ }^{T 3} \mathrm{~m} \mathrm{Ba}$ & $2.147 E+04$ & $1.913 E+04$ & $1.704 E+04$ & $1.518 \mathrm{E}+04$ & $1.353 E+04$ & $1.205 E+04$ & $1.074 E+04$ \\
\hline${ }^{40} \mathrm{Ba}$ & $0.000 E+00$ & $0.000 \mathrm{E}+00$ & $0.000 \mathrm{E}+00$ & $0.000 \mathrm{E}+00$ & $\mathrm{E}+00$ & $E+00$ & $E+00$ \\
\hline${ }^{40} \mathrm{La}$ & +00 & $0.000 E+00$ & $0.000 \mathrm{E}+00$ & $0.000 \mathrm{E}+00$ & $E+00$ & $E+00$ & $=+\infty$ \\
\hline${ }^{4} \mathrm{Ce}$ & $E-55$ & $3.961 \mathrm{E}-72$ & $4.904 \mathrm{E}-89$ & $6.072-106$ & $7.360-123$ & $9.112-140$ & $8-156$ \\
\hline${ }^{2} \mathrm{Ce}$ & -05 & -05 & $1.019 \mathrm{E}-05$ & $1.019 \mathrm{E}-05$ & E-05 & $1.019 \mathrm{E}-05$ & $9 \mathrm{E}-05$ \\
\hline${ }^{4} \mathrm{Ce}$ & $=-02$ & $E-04$ & $3.941 \mathrm{E}-06$ & $4.591 \mathrm{E}-08$ & $=-10$ & $E-12$ & $E-14$ \\
\hline & 0.00 & $E+00$ & $0.000 \mathrm{E}+00$ & $0.000 \mathrm{E}+00$ & $E+00$ & $E+00$ & $E+00$ \\
\hline${ }^{104} \mathrm{Pr}$ & -02 & -04 & $3.942 \mathrm{E}-06$ & $4.591 \mathrm{E}-08$ & $E-10$ & $\mathrm{E}-12$ & E-14 \\
\hline $\mathrm{Pr}^{2}$ & -04 & -06 & $4.730 \mathrm{E}-08$ & $5.510 \mathrm{E}-10$ & $E-12$ & $3 E-14$ & $E-16$ \\
\hline$\sqrt{N d}$ & $=-10$ & -10 & $4.220 \mathrm{E}-10$ & $4.220 \mathrm{E}-10$ & $0 E-10$ & $\mathrm{E}-10$ & $E-10$ \\
\hline${ }^{447} \mathrm{Nd}$ & +00 & 0.00 & $0.000 \mathrm{E}+00$ & $0.000 \mathrm{E}+00$ & $\overline{D E}+00$ & $0.000 \mathrm{E}+00$ & $\overline{E+00}$ \\
\hline$\sqrt[5]{\mathrm{Pm}}$ & -03 & -03 & $3.685 \mathrm{E}-03$ & $3.030 \mathrm{E}-03$ & $=-03$ & E-03 & $E=03$ \\
\hline $\mathrm{Pm}$ & +02 & $7.195 \mathrm{E}+01$ & $1.920 \mathrm{E}+01$ & $5.125 \mathrm{E}+00$ & $E+00$ & $3 \mathrm{E}-01$ & $3 E-02$ \\
\hline${ }^{1480} \mathrm{Pm}$ & -44 & -57 & $1.837 \mathrm{E}-70$ & $8.982 \mathrm{E}-84$ & E-97 & $2-110$ & $3-123$ \\
\hline${ }^{748} \mathrm{Pm}$ & -45 & 58 & E-71 & $5.059 \mathrm{E}-85$ & -98 & $0-111$ & $9-125$ \\
\hline${ }^{145} \mathrm{Sm}$ & $E-07$ & -09 & $6.102 \mathrm{E}-11$ & $1.476 \mathrm{E}-12$ & $=-14$ & $E-16$ & $E-17$ \\
\hline${ }^{147} \mathrm{Sm}$ & -06 & -06 & 1.303E-06 & 1.303E-06 & $E-06$ & BE-06 & $3 \mathrm{E}-06$ \\
\hline${ }^{T 5} \mathrm{Sm}$ & & & +02 & $E+02$ & +02 & +02 & +02 \\
\hline${ }^{152} \mathrm{Eu}$ & +00 & 01 & 01 & $5.065 \mathrm{E}-01$ & -01 & E-01 & $E-01$ \\
\hline${ }^{4} \mathrm{Eu}$ & +02 & $2.399 \mathrm{E}+02$ & $1.604 \mathrm{E}+02$ & $1.072 E+02$ & $E+01$ & $7 \mathrm{E}+01$ & $E+01$ \\
\hline${ }^{755} \mathrm{Eu}$ & +01 & +01 & $1.912 \mathrm{E}+01$ & $9.507 \mathrm{E}+00$ & $=00$ & $2.349 E+00$ & $E+00$ \\
\hline${ }^{6} \mathrm{Eu}$ & 25 & & 0.0 & $\mathrm{JE}+00$ & +00 & $E+00$ & $=+00$ \\
\hline${ }^{153} \mathrm{Gd}$ & $=-07$ & $2.147 \mathrm{E}-09$ & $1.150 \mathrm{E}-11$ & $6.156 \mathrm{E}-14$ & $E-16$ & $E-18$ & -21 \\
\hline${ }^{100} \mathrm{~Tb}$ & & 6.57 & $1.642 \mathrm{E}-41$ & $4.102 E-49$ & $5 E-56$ & $2.534 \mathrm{E}-64$ & $6.331 \mathrm{E}-72$ \\
\hline${ }^{206} \mathrm{TI}$ & & & & $\mathrm{E}-12$ & $E-12$ & $1.459 \mathrm{E}-12$ & $1.459 \mathrm{E}-12$ \\
\hline${ }^{207} \mathrm{TI}$ & -01 & -01 & $7.551 \mathrm{E}-01$ & $8.254 \mathrm{E}-01$ & -01 & EE-01 & -01 \\
\hline${ }^{208} \mathrm{TI}$ & $1.698 \mathrm{E}+02$ & $1.619 \mathrm{E}+02$ & $1.541 \mathrm{E}+02$ & $1.469 \mathrm{E}+02$ & $1.400 \mathrm{E}+02$ & $1.334 E+02$ & $1.271 E+02$ \\
\hline${ }^{210} \mathrm{~Pb}$ & & $1.224 \mathrm{E}-04$ & $1.200 \mathrm{E}-04$ & $1.210 \mathrm{E}-04$ & $E-04$ & $E-04$ & $=-04$ \\
\hline $\mathrm{Pb}$ & & & 7.57 & 8.27 & -01 & $E-01$ & E-01 \\
\hline${ }^{212} \mathrm{~Pb}$ & $4.726 E+02$ & $4.505 E+02$ & $4.290 E+02$ & $4.089 \mathrm{E}+02$ & $3.896 E+02$ & $3.713 E+02$ & $E+02$ \\
\hline${ }^{2 \pi} \mathrm{Bi}$ & -01 & $6.747 \mathrm{E}-01$ & $7.572 \mathrm{E}-01$ & 8.277E-01 & $E-01$ & $9.391 \mathrm{E}-01$ & $9.828 \mathrm{E}-01$ \\
\hline${ }^{212} \mathrm{Bi}$ & +02 & +02 & $4.290 E+02$ & $4.089 E+02$ & +02 & $3.713 \mathrm{E}+02$ & $3.539 E+02$ \\
\hline & $E+02$ & $2.886 \mathrm{E}+02$ & $2.749 \mathrm{E}+02$ & $2.620 \mathrm{E}+02$ & $E+02$ & $2.379 E+02$ & $2.267 E+02$ \\
\hline
\end{tabular}


Table B-6 Calculated Isotopic Activity of the Seed Fuel by Year [Ref. 19] (cont'd)

\begin{tabular}{|c|c|c|c|c|c|c|c|}
\hline \multirow[b]{2}{*}{ Nuclide } & \multicolumn{7}{|c|}{$\begin{array}{l}\text { Isotopic Activity as of Year: } \\
\text { (Ci) }\end{array}$} \\
\hline & 2000 & 2005 & 2010 & 2015 & 2020 & 2025 & 2030 \\
\hline & $5.778 \mathrm{E}-01$ & $6.747 \mathrm{E}-01$ & $7.572 \mathrm{E}-01$ & 8.277E-01 & $8.879 \mathrm{E}-01$ & $9.391 \mathrm{E}-01$ & $9.828 \mathrm{E}-01$ \\
\hline Po & $4.726 \mathrm{E}+02$ & $4.505 \mathrm{E}+02$ & $4.290 \mathrm{E}+02$ & $4.089 \mathrm{E}+02$ & $3.896 \mathrm{E}+02$ & $3.713 \mathrm{E}+02$ & $3.539 \mathrm{E}+02$ \\
\hline${ }^{219} \mathrm{Rn}$ & $5.778 \mathrm{E}-01$ & $6.747 \mathrm{E}-01$ & $7.572 \mathrm{E}-01$ & $8.277 \mathrm{E}-01$ & $8.879 \mathrm{E}-01$ & $9.391 \mathrm{E}-01$ & $9.828 \mathrm{E}-01$ \\
\hline${ }^{220} \mathrm{Rn}$ & $4.726 E+02$ & $4.505 E+02$ & $4.290 \mathrm{E}+02$ & $4.089 \mathrm{E}+02$ & $3.896 \mathrm{E}+02$ & $3.713 \mathrm{E}+02$ & $3.539 E+02$ \\
\hline${ }^{223} \mathrm{Fr}$ & $7.957 \mathrm{E}-03$ & $9.293 \mathrm{E}-03$ & $1.043 \mathrm{E}-02$ & $1.140 \mathrm{E}-02$ & $1.223 \mathrm{E}-02$ & $1.294 \mathrm{E}-02$ & $1.354 \mathrm{E}-02$ \\
\hline${ }^{223} \mathrm{Ra}$ & $5.778 \mathrm{E}-01$ & $6.747 \mathrm{E}-01$ & $7.572 \mathrm{E}-01$ & $8.277 \mathrm{E}-01$ & $8.879 \mathrm{E}-01$ & $9.391 \mathrm{E}-01$ & $9.828 \mathrm{E}-01$ \\
\hline${ }^{224} \mathrm{Ra}$ & $4.726 E+02$ & $4.505 E+02$ & $4.290 \mathrm{E}+02$ & $4.089 E+02$ & $3.896 \mathrm{E}+02$ & $3.713 E+02$ & $3.539 \mathrm{E}+02$ \\
\hline${ }^{226} \mathrm{Ra}$ & $7.430 \mathrm{E}-05$ & $9.464 \mathrm{E}-05$ & $1.158 \mathrm{E}-04$ & $1.376 E-04$ & $1.603 \mathrm{E}-04$ & $1.837 \mathrm{E}-04$ & $2.079 \mathrm{E}-04$ \\
\hline${ }^{228} \mathrm{Ra}$ & $4.303 \mathrm{E}-02$ & $4.489 \mathrm{E}-02$ & $4.600 \mathrm{E}-02$ & $4.666 \mathrm{E}-02$ & $4.706 \mathrm{E}-02$ & $4.729 \mathrm{E}-02$ & $4.743 \mathrm{E}-02$ \\
\hline${ }^{227} \mathrm{AC}$ & $5.766 \mathrm{E}-01$ & $6.734 \mathrm{E}-01$ & $7.559 \mathrm{E}-01$ & $8.262 \mathrm{E}-01$ & $8.862 \mathrm{E}-01$ & $9.374 \mathrm{E}-01$ & $9.810 \mathrm{E}-01$ \\
\hline${ }^{227}$ Th & $5.698 \mathrm{E}-01$ & $6.654 \mathrm{E}-01$ & $7.468 \mathrm{E}-01$ & $8.163 \mathrm{E}-01$ & $8.757 \mathrm{E}-01$ & $9.262 \mathrm{E}-01$ & $9.693 \mathrm{E}-01$ \\
\hline${ }^{228} \mathrm{Th}$ & $4.714 \mathrm{E}+02$ & $4.497 \mathrm{E}+02$ & $4.286 E+02$ & $4.085 E+02$ & $3.893 E+02$ & $3.710 E+02$ & $3.536 \mathrm{E}+02$ \\
\hline${ }^{229} \mathrm{Th}$ & $2.689 \mathrm{E}-01$ & $3.298 \mathrm{E}-01$ & $3.906 \mathrm{E}-01$ & $4.514 \mathrm{E}-01$ & $5.122 \mathrm{E}-01$ & $5.730 \mathrm{E}-01$ & $6.337 \mathrm{E}-01$ \\
\hline${ }^{230} \mathrm{Th}$ & $9.288 \mathrm{E}-03$ & $9.665 \mathrm{E}-03$ & $1.004 \mathrm{E}-02$ & $1.042 \mathrm{E}-02$ & $1.080 \mathrm{E}-02$ & $1.118 \mathrm{E}-02$ & $1.155 \mathrm{E}-02$ \\
\hline${ }^{231} \mathrm{Th}$ & $6.271 \mathrm{E}-04$ & $6.271 E-04$ & $6.271 \mathrm{E}-04$ & $6.271 \mathrm{E}-04$ & $6.271 \mathrm{E}-04$ & $6.271 \mathrm{E}-04$ & $6.271 \mathrm{E}-04$ \\
\hline${ }^{232} \mathrm{Th}$ & $4.764 \mathrm{E}-02$ & $4.764 \mathrm{E}-02$ & $4.764 \mathrm{E}-02$ & $4.764 \mathrm{E}-02$ & $4.764 E-02$ & $4.764 E-02$ & $4.764 \mathrm{E}-02$ \\
\hline${ }^{234} \mathrm{Th}$ & $1.814 \mathrm{E}-05$ & 1.814E-05 & $1.814 \mathrm{E}-05$ & $1.814 \mathrm{E}-05$ & $1.814 \mathrm{E}-05$ & $1.814 \mathrm{E}-05$ & $1.814 \mathrm{E}-05$ \\
\hline${ }^{231} \mathrm{~Pa}$ & $1.234 E+00$ & $=+00$ & $1.234 \mathrm{E}+00$ & $1.234 \mathrm{E}+00$ & $1.234 \mathrm{E}+00$ & $1.234 \mathrm{E}+00$ & $1.234 \mathrm{E}+00$ \\
\hline${ }^{233} \mathrm{~Pa}$ & $1.273 \mathrm{E}-03$ & $E-03$ & $1.279 \mathrm{E}-03$ & $1.283 \mathrm{E}-03$ & $1.286 \mathrm{E}-03$ & $1.290 \mathrm{E}-03$ & $1.294 \mathrm{E}-03$ \\
\hline${ }^{2344} \mathrm{~Pa}$ & $1.814 \mathrm{E}-05$ & $1.814 \mathrm{E}-05$ & $1.814 \mathrm{E}-05$ & $1.814 \mathrm{E}-05$ & $1.814 \mathrm{E}-05$ & $1.814 \mathrm{E}-05$ & 1.814E-05 \\
\hline${ }^{2 * 4} \mathrm{~Pa}$ & $2.358 \mathrm{E}-08$ & -08 & $2.358 \mathrm{E}-08$ & $2.358 \mathrm{E}-08$ & $8 \mathrm{E}-08$ & $2.358 \mathrm{E}-08$ & $2.358 \mathrm{E}-08$ \\
\hline${ }^{232} \mathrm{U}$ & $4.593 E+02$ & $4.378 \mathrm{E}+02$ & $4.172 \mathrm{E}+02$ & $3.976 E+02$ & $3.789 E+02$ & $3.611 \mathrm{E}+02$ & $3.441 E+02$ \\
\hline $\mathrm{U}$ & $1.292 E+02$ & $1.292 E+02$ & $1.292 E+02$ & $1.292 E+02$ & $1.292 \mathrm{E}+02$ & $1.292 \mathrm{E}+02$ & $1.292 \mathrm{E}+02$ \\
\hline${ }^{34} \mathrm{U}$ & $8.397 \mathrm{E}+00$ & 8.35 & 8.397 & $8.397 E+00$ & $7 E+00$ & $8.397 \mathrm{E}+00$ & $8.397 \mathrm{E}+00$ \\
\hline${ }^{235} \mathrm{U}$ & $6.271 \mathrm{E}-04$ & $6.271 E-04$ & $6.271 \mathrm{E}-04$ & $6.271 \mathrm{E}-04$ & $6.271 \mathrm{E}-04$ & $6.271 \mathrm{E}-04$ & $6.271 \mathrm{E}-04$ \\
\hline${ }^{5}$ & $1.363 \mathrm{E}-03$ & $1.363 \mathrm{E}-03$ & $1.363 \mathrm{E}-03$ & $1.363 \mathrm{E}-03$ & $1.363 \mathrm{E}-03$ & $1.363 E-03$ & 1.363E-03 \\
\hline${ }^{23 \pi} \mathrm{U}$ & $8.553 \mathrm{E}-06$ & .06 & 5.28 & EE-06 & $3.266 \mathrm{E}-06$ & $2.567 \mathrm{E}-06$ & $2.018 \mathrm{E}-06$ \\
\hline $238 \mathrm{U}$ & $1.814 \mathrm{E}-05$ & 05 & 1.814 & $1.814 \mathrm{E}-05$ & $1.814 \mathrm{E}-05$ & $1.814 \mathrm{E}-05$ & 1.814E-05 \\
\hline${ }^{237} \mathrm{~Np}$ & $1.273 \mathrm{E}-03$ & $1.276 \mathrm{E}-03$ & 1.279 & $1.283 \mathrm{E}-03$ & $1.286 \mathrm{E}-03$ & $1.290 \mathrm{E}-03$ & $1.294 \mathrm{E}-03$ \\
\hline${ }^{236} \mathrm{Pu}$ & $7.883 \mathrm{E}-06$ & E-06 & 6.95 & $2.083 \mathrm{E}-07$ & $4 \mathrm{E}-08$ & $2.078 \mathrm{E}-08$ & 8.072E-09 \\
\hline${ }^{237} \mathrm{Pu}$ & -46 & -58 & 6.719 & $3 \mathrm{E}-82$ & $1 E-94$ & $4.544-106$ & $4.009-118$ \\
\hline${ }^{238} \mathrm{Pu}$ & $=+00$ & $E+00$ & $4.625 E+00$ & $4.446 \mathrm{E}+00$ & $4.274 \mathrm{E}+00$ & $4.109 \mathrm{E}+00$ & $3.951 E+00$ \\
\hline${ }^{239} \mathrm{Pu}$ & 2.8 & $E-01$ & 2.82 & $2.822 \mathrm{E}-01$ & 1 E-01 & $2.821 \mathrm{E}-01$ & $2.820 \mathrm{E}-01$ \\
\hline${ }^{240} \mathrm{Pu}$ & $=01$ & 1. & 1.65 & $1.659 \mathrm{E}-01$ & $9 \mathrm{E}-01$ & $1.659 \mathrm{E}-01$ & 1.658E-01 \\
\hline${ }^{241} \mathrm{Pu}$ & 3.48 & +01 & $2.154 \mathrm{E}+01$ & $1.694 E+01$ & $1.331 \mathrm{E}+01$ & $1.046 \mathrm{E}+01$ & $8.227 \mathrm{E}+00$ \\
\hline${ }^{242} \mathrm{Pu}$ & $4.184 \mathrm{E}-04$ & E-04 & 4.184 & $5 \mathrm{E}-04$ & $5 E-04$ & $4.185 \mathrm{E}-04$ & $4.185 \mathrm{E}-04$ \\
\hline${ }^{244} \mathrm{Pu}$ & $E-11$ & & 5.38 & $E-11$ & $\mathrm{E}-11$ & $5.389 \mathrm{E}-11$ & $5.389 E-11$ \\
\hline${ }^{241} \mathrm{Am}$ & $1.6 \mathrm{~s}$ & 1.9 & $2.105 E+00$ & $2.241 E+00$ & $2.344 \mathrm{E}+00$ & $2.420 \mathrm{E}+00$ & $2.474 E+00$ \\
\hline${ }^{242 M} \mathrm{Am}$ & $1.645 \mathrm{E}-02$ & 02 & $1.572 \mathrm{E}-02$ & $1.537 \mathrm{E}-02$ & $1.502 \mathrm{E}-02$ & $1.468 \mathrm{E}-02$ & 1.435E-02 \\
\hline${ }^{242} \mathrm{Am}$ & $1.637 \mathrm{E}-02$ & -02 & 1.564 & $1.529 \mathrm{E}-02$ & $4 \mathrm{E}-02$ & $1.461 \mathrm{E}-02$ & $1.428 \mathrm{E}-02$ \\
\hline${ }^{243} \mathrm{Am}$ & -03 & & 3.195 & $3.194 \mathrm{E}-03$ & $3.192 \mathrm{E}-03$ & $3.191 \mathrm{E}-03$ & $3.189 \mathrm{E}-03$ \\
\hline${ }^{242} \mathrm{Cm}$ & 1.356E-02 & 1.326E-02 & 1.294E-02 & $1.265 \mathrm{E}-02$ & $1.236 \mathrm{E}-02$ & $1.209 \mathrm{E}-02$ & $1.181 \mathrm{E}-02$ \\
\hline${ }^{243} \mathrm{Cm}$ & 4.793E-03 & -03 & -03 & $3.328 \mathrm{E}-03$ & $2.947 \mathrm{E}-03$ & $2.609 \mathrm{E}-03$ & $2.311 \mathrm{E}-03$ \\
\hline${ }^{244} \mathrm{Cm}$ & 2.826E-01 & -01 & 1.927 & $1.592 \mathrm{E}-01$ & $1.314 \mathrm{E}-01$ & $1.085 \mathrm{E}-01$ & $8.964 \mathrm{E}-02$ \\
\hline${ }^{240} \mathrm{Cm}$ & $2 \mathrm{E}-05$ & $7.139 \mathrm{E}-05$ & $7.136 \mathrm{E}-05$ & 7.134E-05 & $7.131 \mathrm{E}-05$ & $7.128 \mathrm{E}-05$ & $7.125 \mathrm{E}-05$ \\
\hline${ }^{246} \mathrm{Cm}$ & $4.734 \mathrm{E}-06$ & 4.730E-06 & $4.727 \mathrm{E}-06$ & $4.723 \mathrm{E}-06$ & $4.720 \mathrm{E}-06$ & $4.716 \mathrm{E}-06$ & $4.713 \mathrm{E}-06$ \\
\hline${ }^{241} \mathrm{Cm}$ & $1.674 E-11$ & $E-11$ & -11 & $1.674 \mathrm{E}-11$ & $1.674 \mathrm{E}-11$ & $1.674 E-11$ & $1.674 \mathrm{E}-11$ \\
\hline sum & $9.771 \mathrm{E}+04$ & $8.640 \mathrm{E}+04$ & $7.669 E+04$ & $6.820 \mathrm{E}+04$ & $6.072 E+04$ & $5.411 E+04$ & $4.826 \mathrm{E}+04$ \\
\hline
\end{tabular}

'The basis for the ORIGEN2 simulation is a Seed assembly. The initial fissile loading of the simulated assembly is $16,892.84 \mathrm{~g}$, which is approximately $2 \%$ greater than the actual initial fissile loading. The simulated burnup is $10,269.14 \mathrm{MWd}$ for the assembly. 


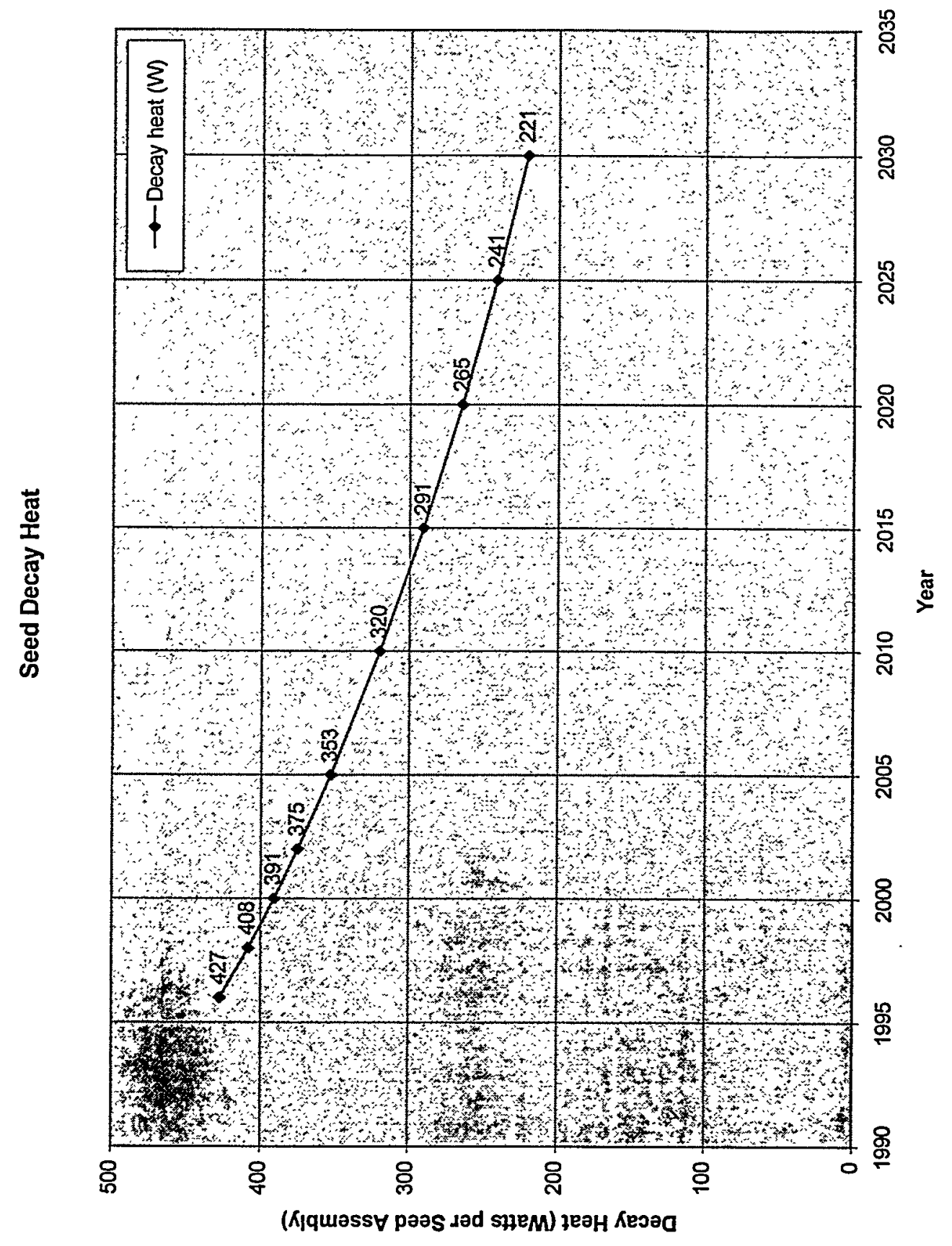

$\infty$
1
$\infty$ 


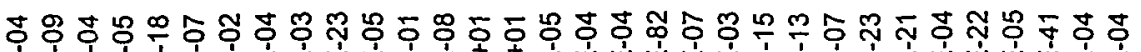

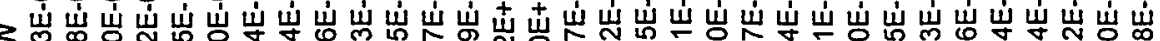

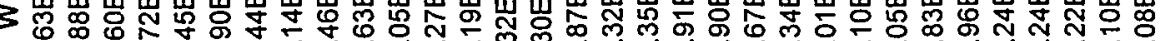
๓ N N N N

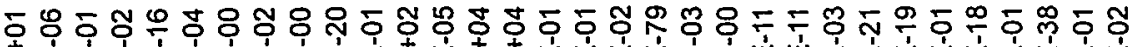

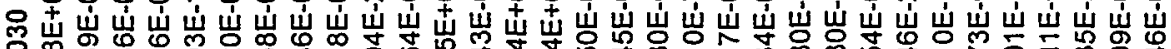

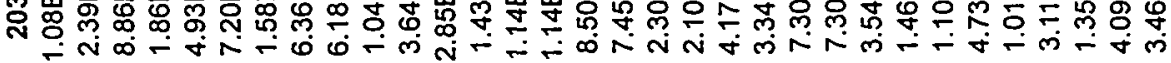

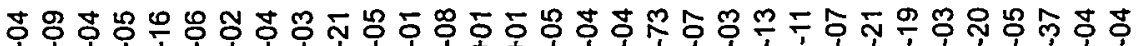

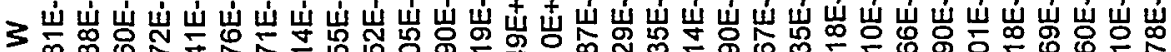
จ N N

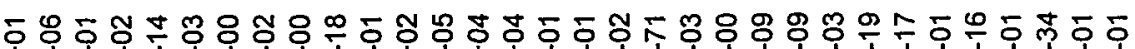

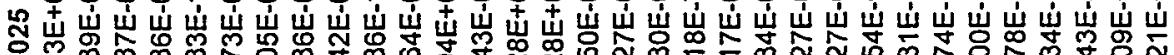

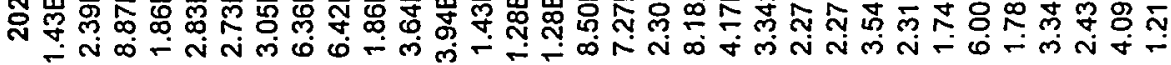

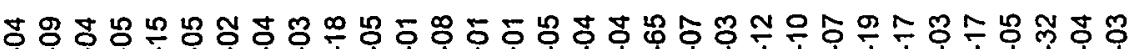

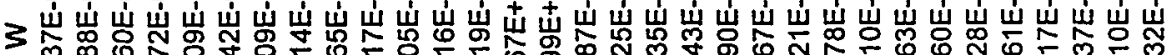
চ N

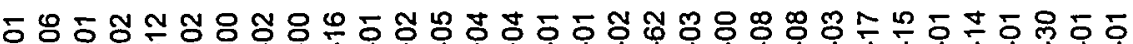

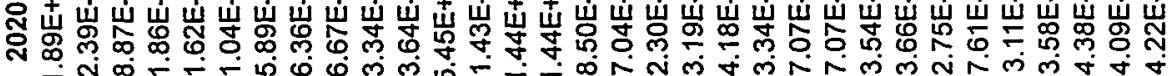

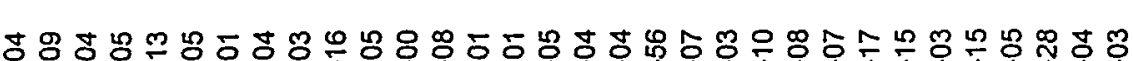

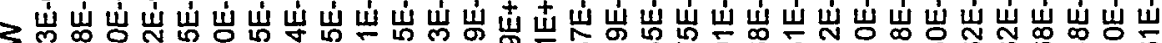
চ

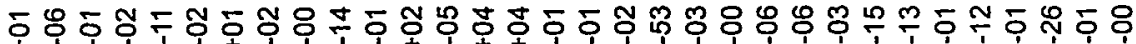

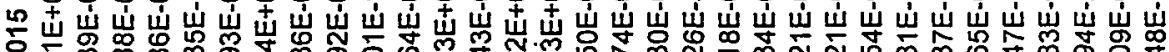

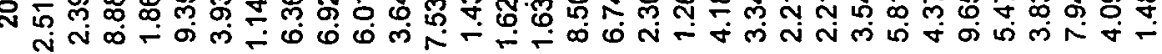

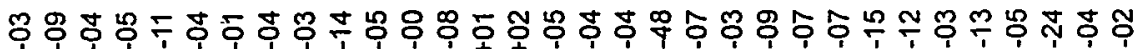

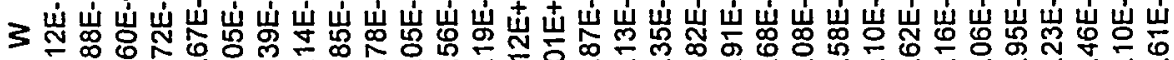

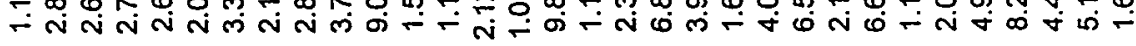

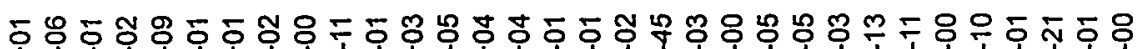

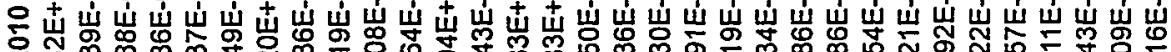
侘

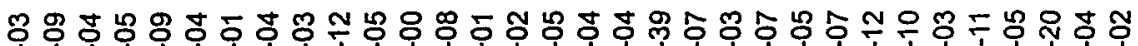

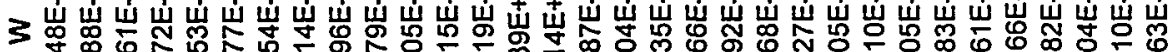

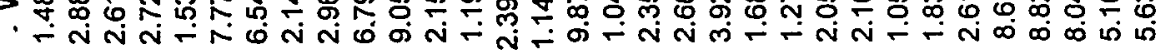

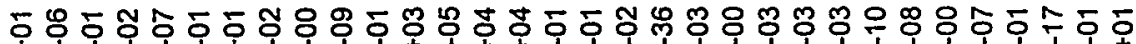

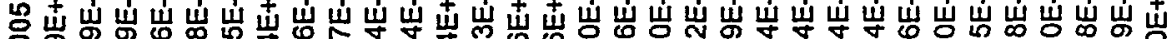

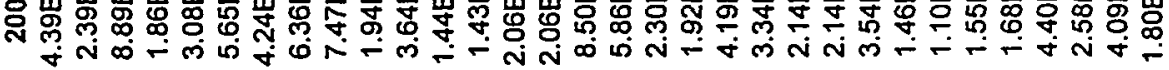

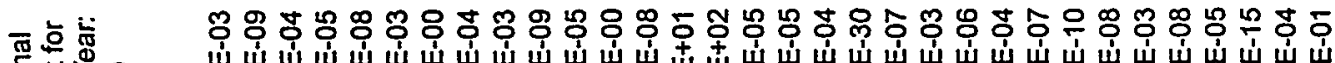

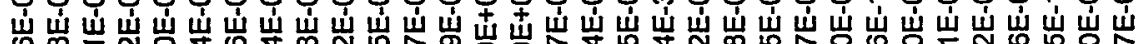

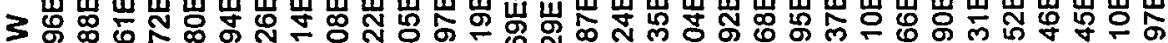

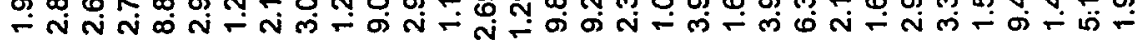

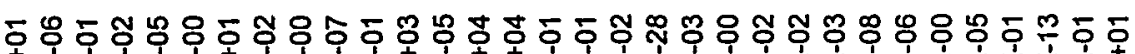

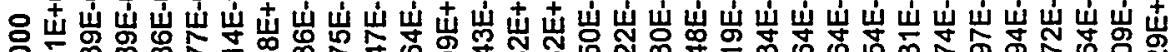

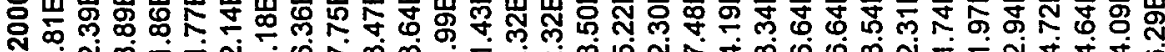

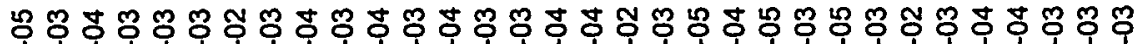
ত

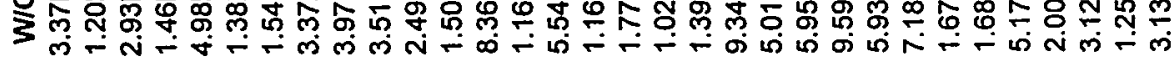

$r$.

ต่

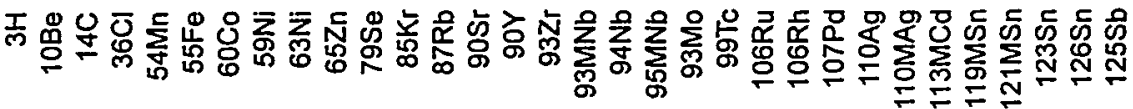


\%

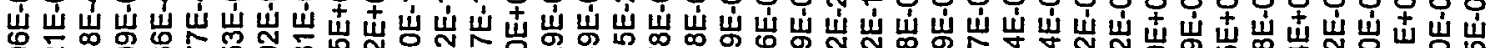

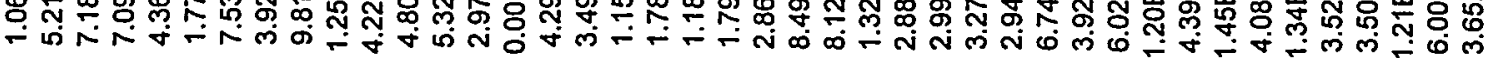

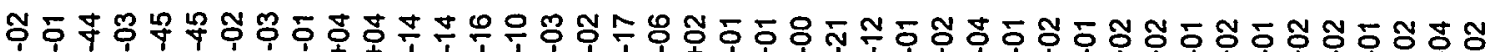

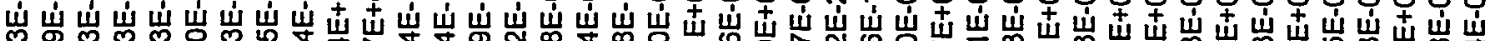

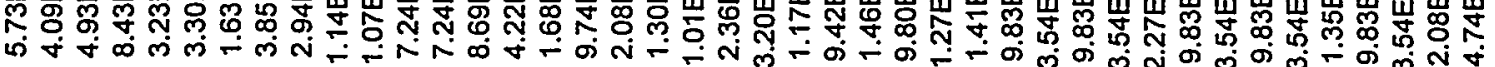

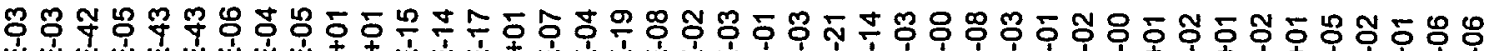

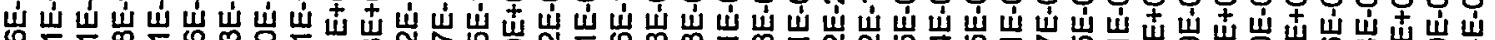

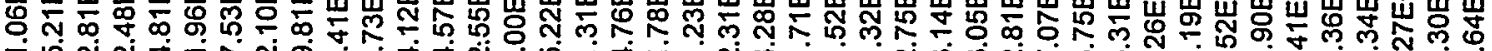

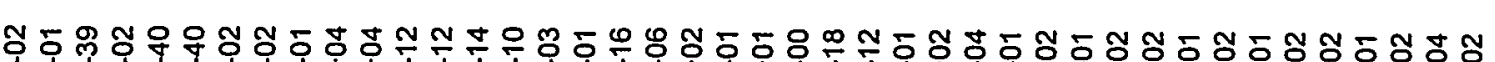

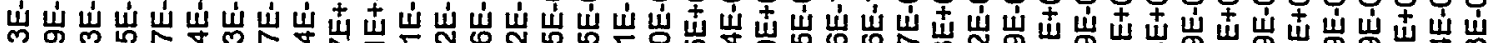

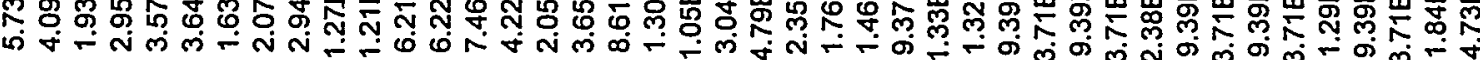

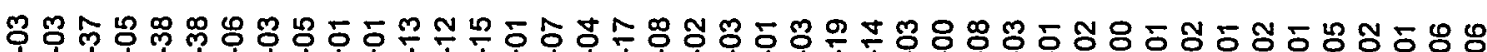

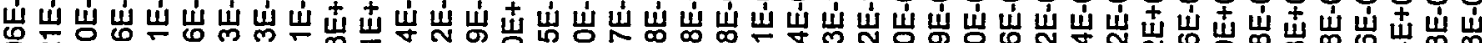

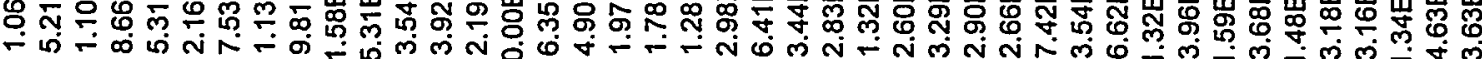

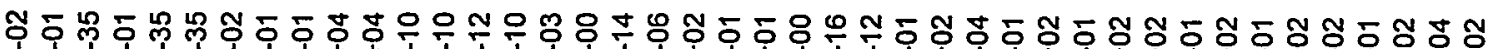

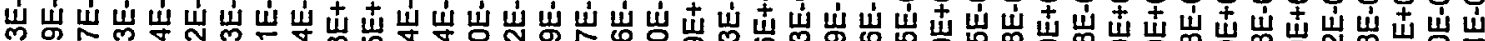

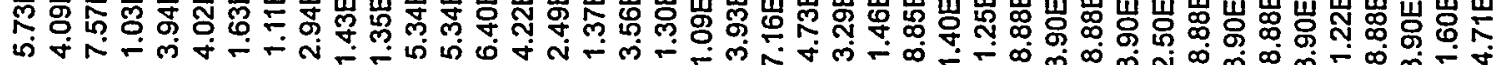

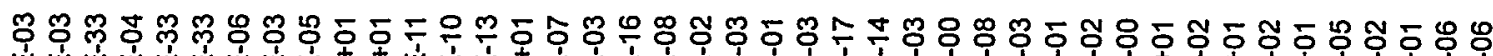

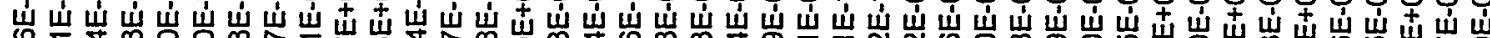

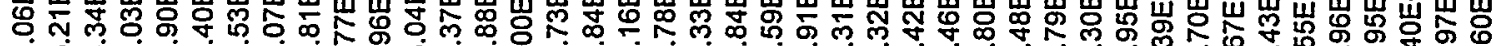

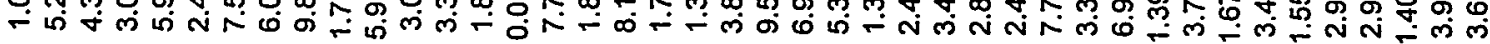

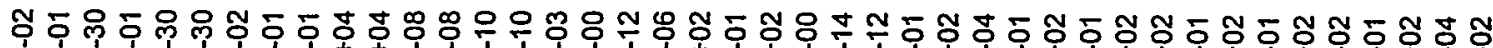

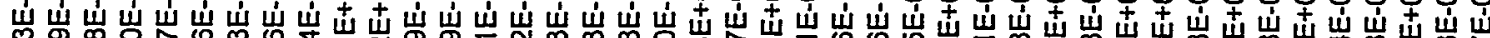

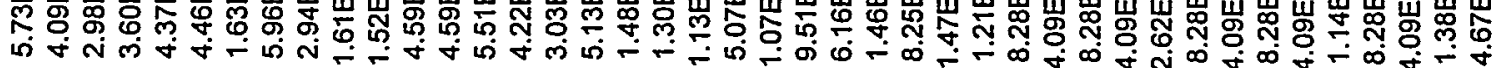

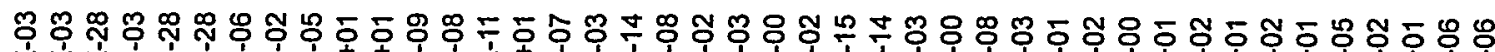

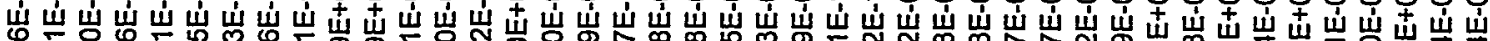

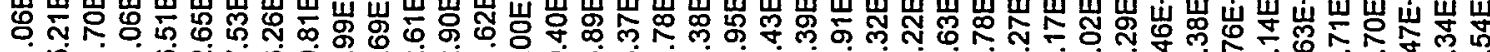

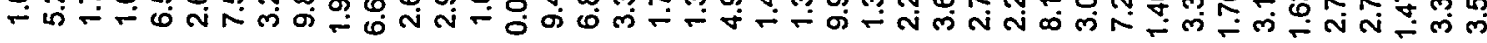

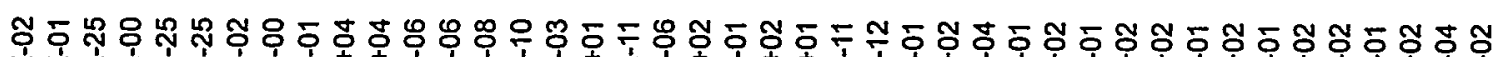

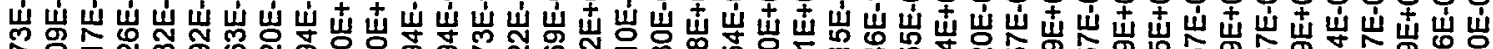

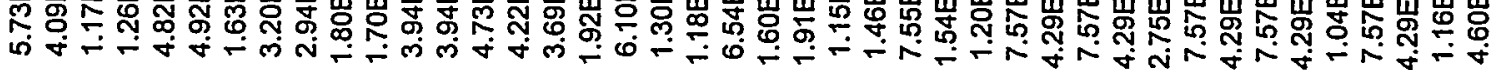

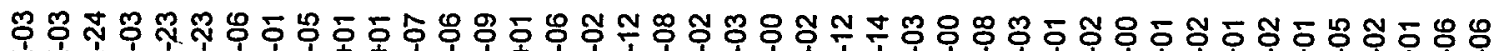

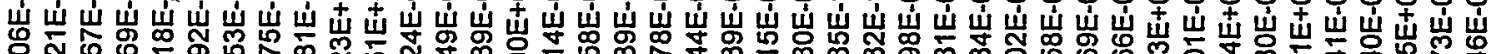

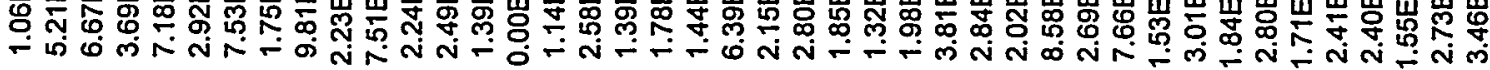

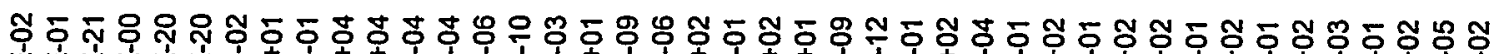

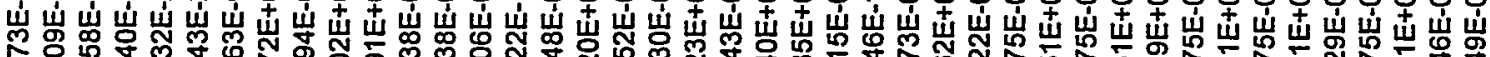

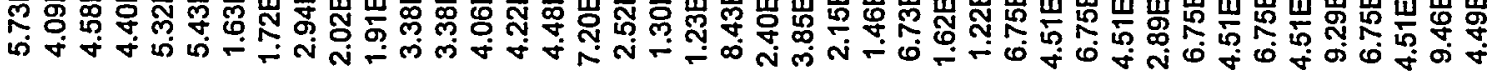

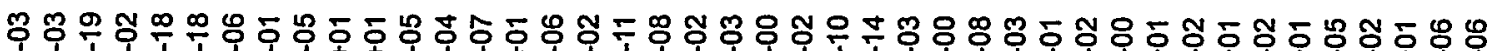

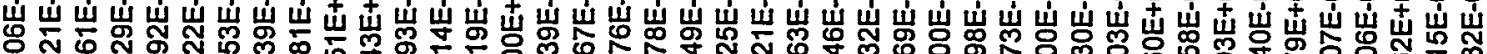

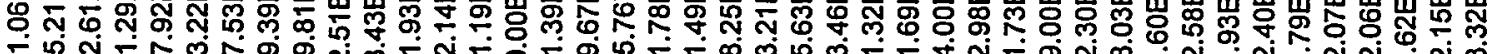

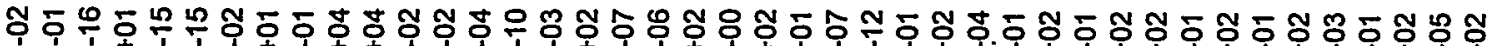

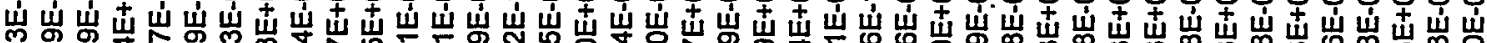

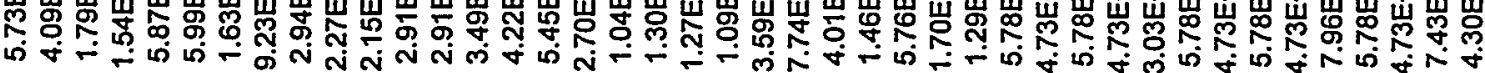

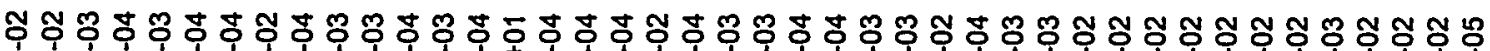

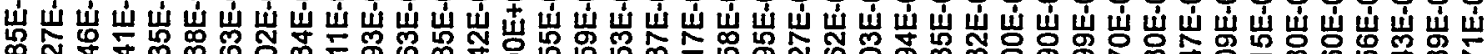

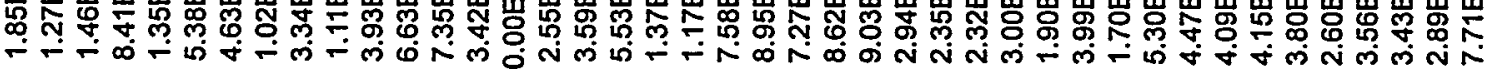

总 की

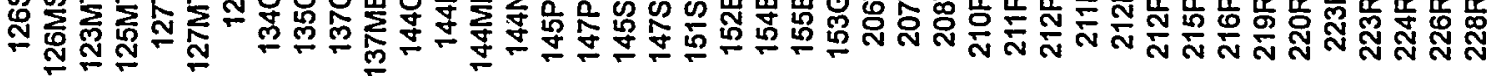




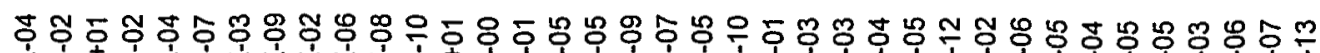

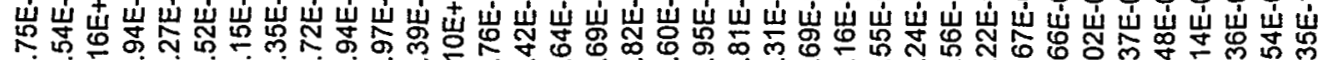

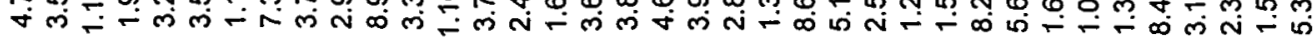

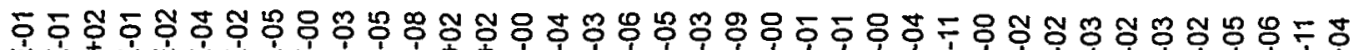

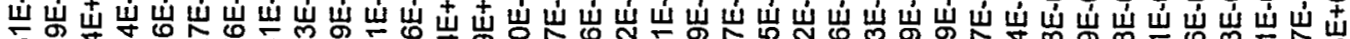
চ

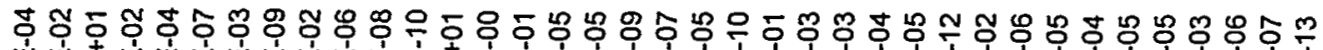

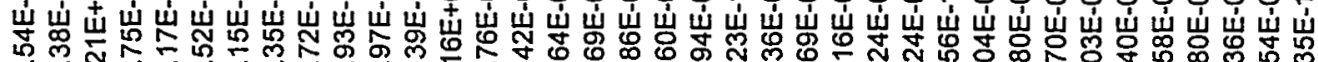

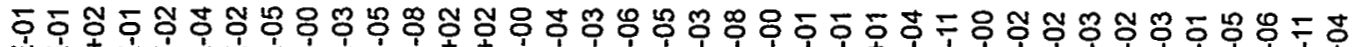

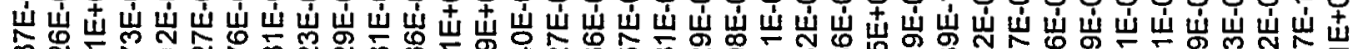

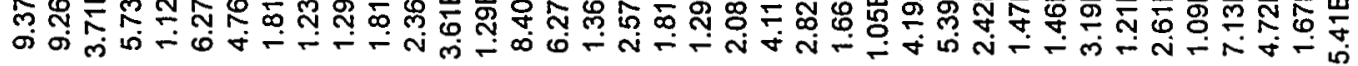

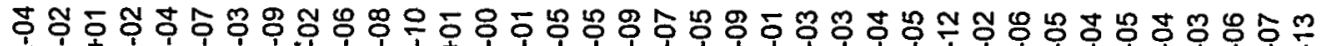

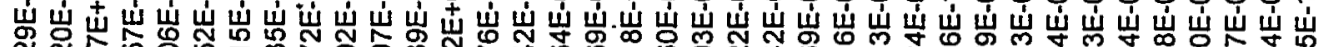

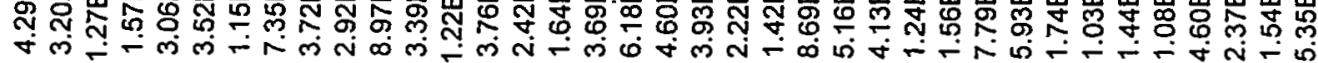

ธ్రธ

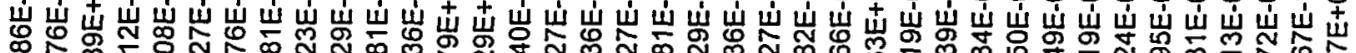

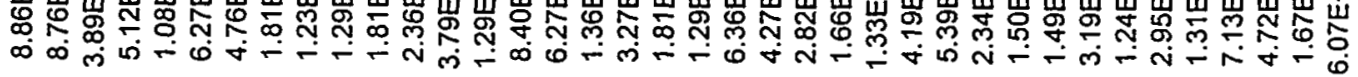

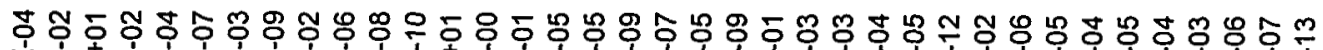

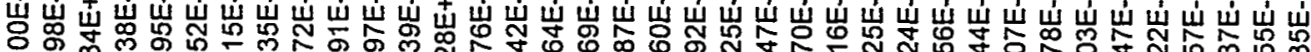

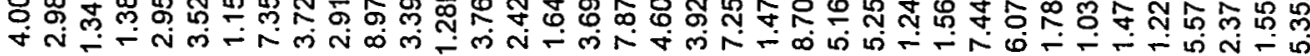

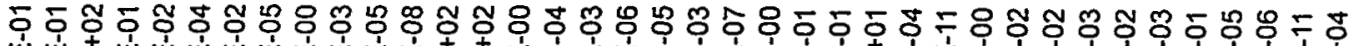

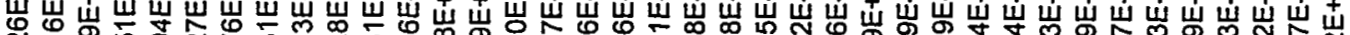

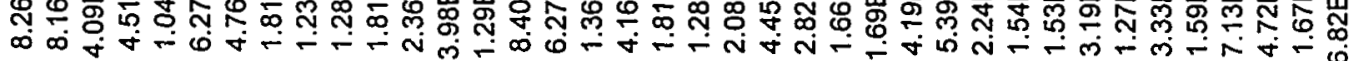

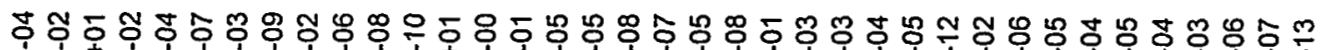

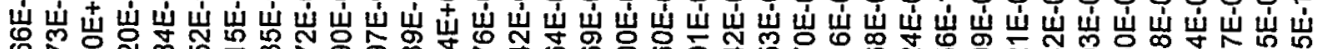
户 N

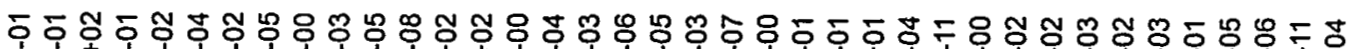

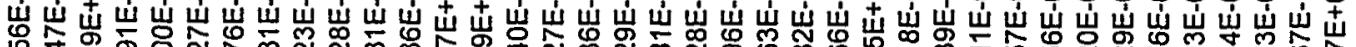

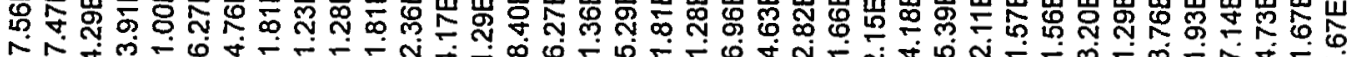

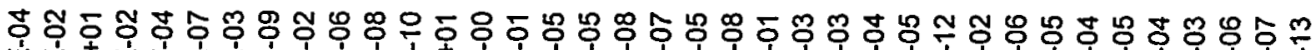

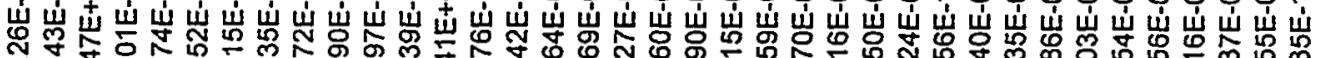

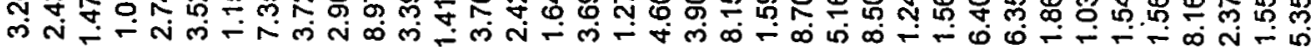

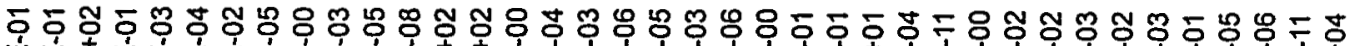

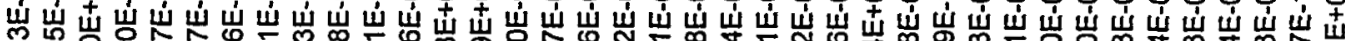

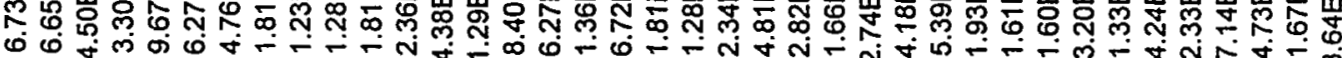

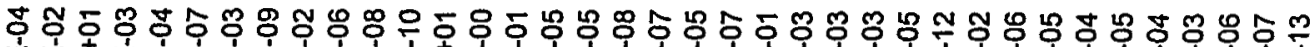

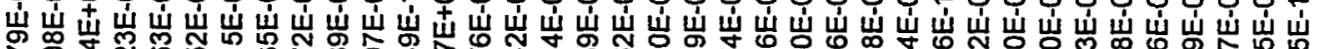
숱

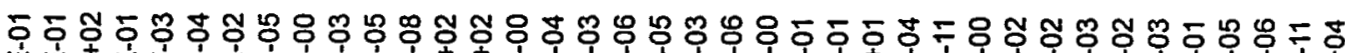

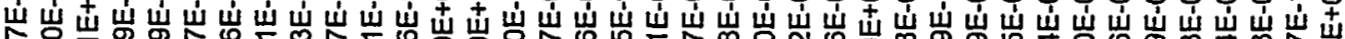

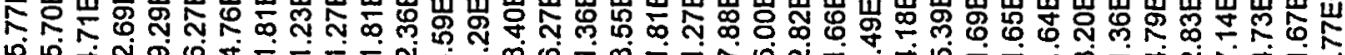

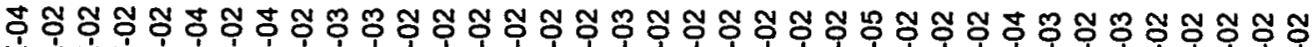

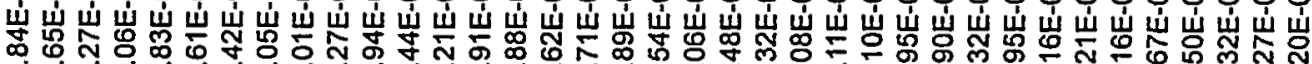
ఫ

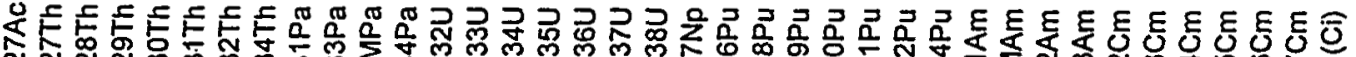
สิ่ 

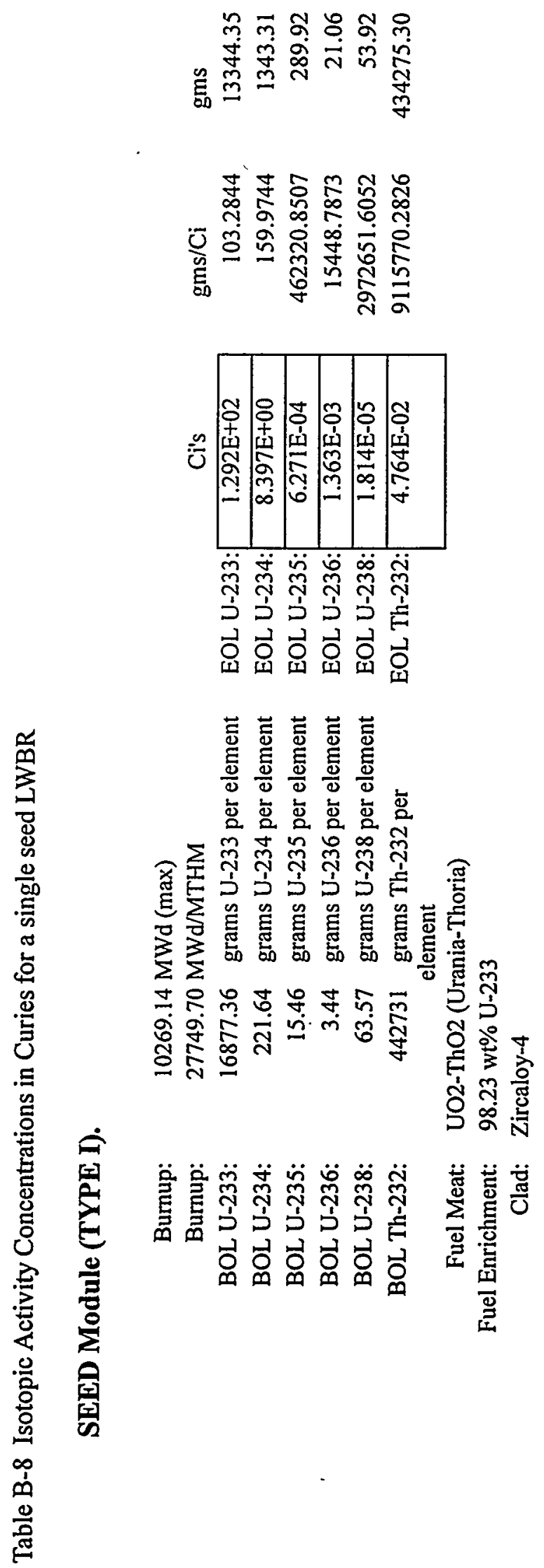


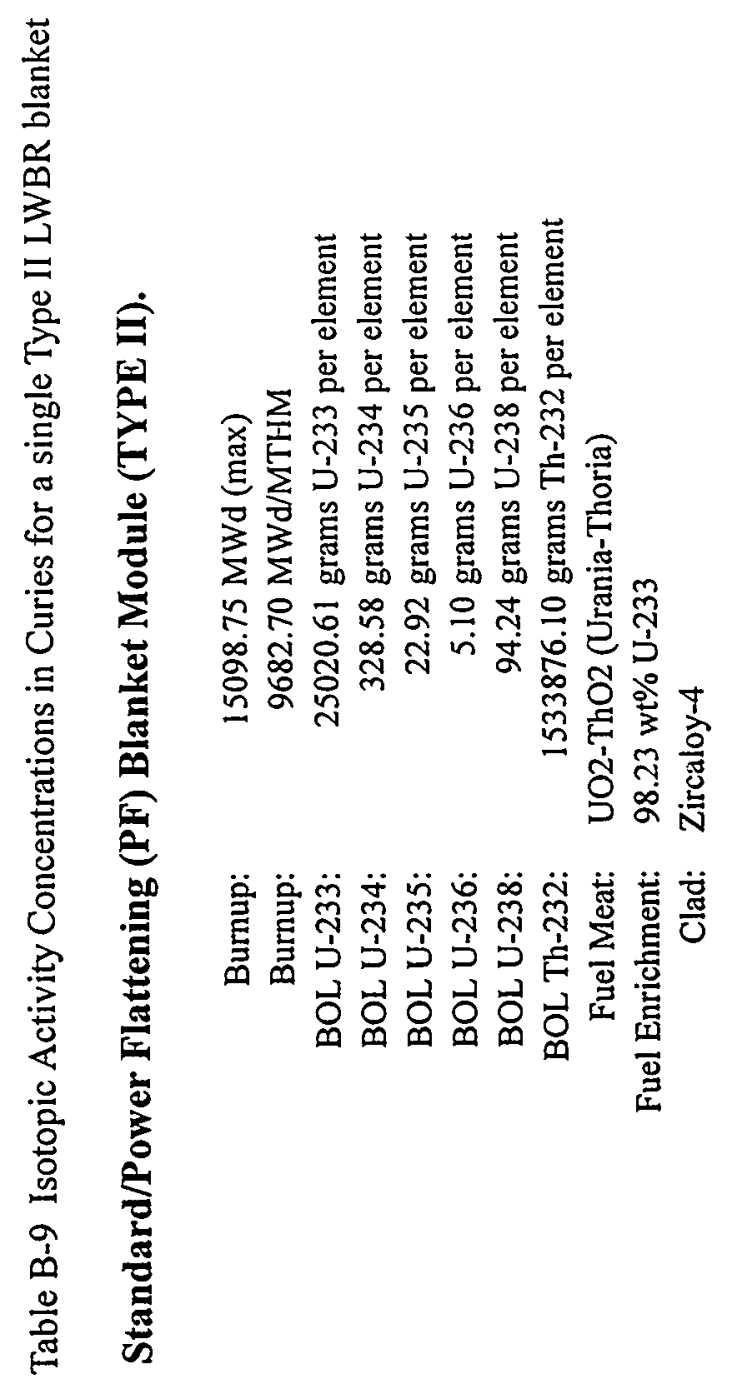

$\frac{m}{m}$ 


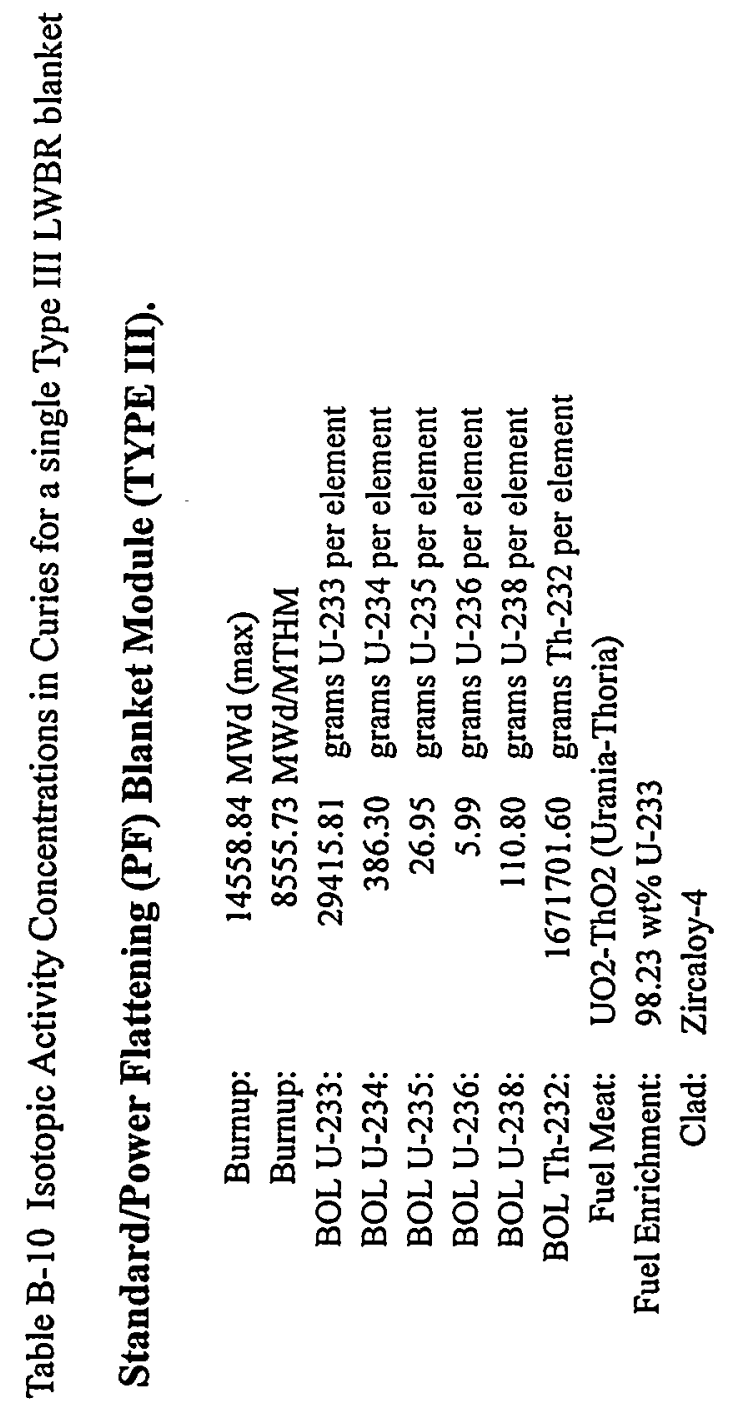

吉 